\title{
Theoretical Studies of the Tautomerism in 3-(2-R-Phenylhydrazono)-naphthalene- 1,2,4-triones: Synthesis of Copper(II) Complexes and Studies of Antibacterial and Antitumor Activities
}

\author{
Acácio I. Francisco, ${ }^{a}$ Maria D. Vargas, ${ }^{*, a}$ Thaís P. Fragoso, ${ }^{a}$ J. Walkimar de M. Carneiro, ${ }^{a}$ \\ Annelise Casellato, ${ }^{b}$ Fernando de C. da Silva, ${ }^{a}$ Vitor F. Ferreira, ${ }^{a}$ Jussara P. Barbosa,${ }^{c}$ Claudia Pessoa, ${ }^{d}$ \\ Letícia V. Costa-Lotufo, ${ }^{d}$ José D. B. Marinho Filho, ${ }^{d}$ Manoel O. de Moraes ${ }^{d}$ and Antonio S. Mangrich ${ }^{e}$ \\ ${ }^{a}$ Instituto de Química, Universidade Federal Fluminense, Campus do Valonguinho, Centro, \\ 24020-150 Niterói-RJ, Brazil \\ ${ }^{b}$ Instituto de Química, Universidade Federal do Rio de Janeiro, Ilha do Fundão, 21945-970 Rio de Janeiro-RJ, Brazil \\ 'Instituto Oswaldo Cruz, FIOCRUZ, CP 926, 21045-900 Rio de Janeiro-RJ, Brazil \\ ${ }^{d}$ Universidade Federal do Ceará, Depto de Fisiologia e Farmacologia, Campus do Porangabussu, \\ 60430-270 Fortaleza-CE, Brazil \\ ${ }^{e}$ Departamento de Química da Universidade Federal do Paraná, 81531-990 Curitiba-PR, Brazil
}

\begin{abstract}
Cálculos teóricos utilizando os funcionais B3LYP e PBE1PBE e as bases 6-31G(d) e 6-311+G(2d,p) para o sistema 3-(2-fenil-hidrazona)-naftaleno-1,2,4-triona, em solução (dmso) e em fase gasosa, evidenciaram, em ambos os casos, a maior estabilidade da forma ceto-hidrazona (rotâmeros Ia e Ib) comparada às formas enol-azo (rotâmeros IIa/IIb, por volta de $14 \mathrm{kcal} \mathrm{mol}^{-1}$ ) e III (aproximadamente $6 \mathrm{kcal} \mathrm{mol}^{-1}$ ). A natureza do substituinte no grupo fenil não influenciou a estabilidade relativa dos tautômeros. Estes resultados foram confirmados por dados espectroscópicos dos derivados HL1-HL13, sintetizados a partir da 2-hidroxi-1,4-naftoquinona e arilaminas ( $\mathrm{R}=4-\mathrm{OMe}, 4-\mathrm{N}_{2}-\mathrm{C}_{6} \mathrm{H}_{5}$, 4-Cl, 4-I, 3-I, 2-I, 4-COOH, 3-COOH, 4-CN, 3-CN, 4- $\mathrm{NO}_{2}$, 3-NO, $2-\mathrm{NO}_{2}$ ). A avaliação da atividade anticâncer in vitro (contra linhagens de células cancerosas SF-295, HCT-8, MDAMB-435 e HL-60) e bactericida (Bacillus cereus, Bacillus subtilis, Enterococcus faecalis, Staphylococcus aureus, Escherichia coli, Klebsiella pneumonia e Pseudomonas aeruginosa) dos compostos HL1-HL13 e dos seus respectivos complexos de cobre(II), [Cu(L1-13) ], foi avaliada. Em geral a atividade bactericida foi baixa, exceto para o derivado HL5 $(\mathrm{R}=3-\mathrm{I})$, mais ativo do que o controle; entretanto, seu complexo não foi ativo. Por outro lado, a complexação levou, em geral, ao aumento da atividade antitumoral dos pré-ligantes. $\mathrm{O}$ complexo $\left[\mathrm{Cu}(\mathbf{L 1 3})_{2}\right]\left(\mathrm{R}=3-\mathrm{NO}_{2}\right)$ apresentou moderada citotoxicidade contra leucemia humana (HL-60).
\end{abstract}

DFT calculations using the B3LYP and PBE1PBE functionals with the standard 6-31G(d) and 6-311+G(2d,p) basis sets were carried out for the 3-(2-phenylhydrazone)-naphthalene-1,2,4-trione system in solution (dmso) and in the gas phase, and showed the keto-hydrazone forms (rotamers Ia and Ib) to be more stable than the enol-azo forms (rotamers IIa and IIIb, by about $14 \mathrm{kcal} \mathrm{mol}^{-1}$ ) and III (by approximately $6 \mathrm{kcal} \mathrm{mol}^{-1}$ ), independently of the nature of the substituent in the phenylene ring. These results were confirmed by spectroscopic data on the derivatives HL1-HL13, obtained from 2-hydroxy-1,4-naphthoquinone and arylamines $\left(\mathrm{R}=4-\mathrm{OMe}, 4-\mathrm{N}_{2}-\mathrm{C}_{6} \mathrm{H}_{5}, 4-\mathrm{Cl}\right.$, 4-I, 3-I, 2-I, 4-COOH, 3-COOH, 4-CN, 3-CN, 4-NO, 3-NO, 2- $\mathrm{NO}_{2}$ ). The in vitro antitumor (against SF-295, HCT-8, MDAMB-435 and HL-60 cancer cell lines) and antibacterial activities (Bacillus cereus, Bacillus subtilis, Enterococcus faecalis, Staphylococcus aureus, Escherichia coli, Klebsiella pneumonia and Pseudomonas aeruginosa) of compounds HL1-HL13 and of their respective copper(II) complexes, $\left[\mathrm{Cu}(\mathbf{L 1 - 1 3})_{2}\right]$, were tested. In general, these compounds exhibited low antibacterial activity, except for HL5 ( $\mathrm{R}=3-\mathrm{I})$, more active than the control; however, the corresponding complex was inactive. In contrast, increased cytotoxicity was observed upon complexation. Complex $\left[\mathrm{Cu}(\mathbf{L 1 3})_{2}\right]\left(\mathrm{R}=3-\mathrm{NO}_{2}\right)$ presented moderate cytotoxicity against human leukemia (HL-60).

Keywords: naphthoquinones, copper(II) complexes, tautomerism, hydrazone compounds, antibacterial activity, antitumor activity

\footnotetext{
*e-mail: mdvargas@vm.uff.br
} 


\section{Introduction}

The 1,2 and 1,4-naphthoquinone nuclei are commonly encountered in natural products ${ }^{1,2}$ and their derivatives are found to exhibit an interesting range of pharmacological properties including antibacterial, ${ }^{3-6}$ antiviral, ${ }^{7,8}$ trypanocidal, ${ }^{9-11}$ anticancer, ${ }^{12-14}$ antimalarial, ${ }^{15-17}$ antifunga $1^{18,19}$ and moluscicide ${ }^{20}$ activities. Such properties are due to the interference of quinones in the electron transport chain by electron reduction processes, generating semiquinone radical $\left(\mathrm{Q}^{-}\right)$and hydroquinone anion $\left(\mathrm{Q}^{2-}\right) .^{21,22}$

Azo dyes with ortho and para hydroxy substituents to the azo linker generally exhibit azo-hydrazone tautomerism, which involves transfer of the hydroxyl hydrogen to one of the nitrogens in the azo group. ${ }^{23}$ Tautomeric forms can be identified from their spectral propertie ${ }^{24}$ and the stability of such forms in solution may be influenced by the nature of the substituents present in the molecules. ${ }^{25}$

Incorporation of an azo group into 2-hydroxy-1,4naphthoquinone has led to promising antimalarial and anticancer agents, in which metal complexation with copper(II) resulted in increased cytotoxicity. ${ }^{26,27}$ The derivatives can be represented by several tautomeric structures illustrated in Figure 1: 3-(2-R-phenylhydrazono)naphthalene-1,2,4-triones, Ia and Ib, 3-R-arylazo-4hydroxy-1,2-naphthoquinones, IIa and IIIb, and 3-R-arylazo2-hydroxy-1,4-naphthoquinone III. A poor X-ray diffraction study of the derivative containing $\mathrm{R}=3$-Me suggested that this compound exists as tautomer IIa in the solid state. ${ }^{26}$<smiles>O=c1c(=NNc2ccccc2)c(=O)c2ccccc2c1=O</smiles><smiles>O=c1c(=NNc2ccccc2)c(=O)c2ccccc2c1=O</smiles><smiles>O=C1C(=O)c2ccccc2C(O)=C1N=Nc1ccccc1</smiles><smiles>O=C1C(=O)c2ccccc2C(O)=C1N=Nc1ccccc1</smiles><smiles>O=C1C(O)=C(N=Nc2ccccc2)C(=O)c2ccccc21</smiles>

Figure 1. Tautomeric forms for dyes derived from lawsone and diazonium salts of arylamines.
Knowledge of the geometry and electronic structures, as well as the relative stabilities of the various tautomeric forms in solution, is of utmost importance as it provides a basis for understanding the pharmacological properties of the molecules and designing new derivatives with improved activity. ${ }^{26,27}$ In the present work we describe the results of our theoretical calculations using density functional theory (DFT) carried out to investigate the relative stability of the tautomeric forms of 3-(2-R-phenylhydrazono)naphthalene-1,2,4-trione derivatives (Figure 1) as a function of the substituent, both in the gas phase and in solution. Low solubility prevented experimental NMR experiments. ${ }^{25}$ Some of these compounds have been previously described, ${ }^{26,27,30,31}$ but their tautomerism has not yet been investigated. In addition to reporting the synthesis of novel compounds (HL1-HL13), we also present the results of in vitro antitumor screening and antibacterial activity of these compounds and of their copper(II) complexes (Scheme 1) against several cancer cell lines (SF-295, HCT-8, MDAMB-435 and HL-60) and bacteria strains (Bacillus cereus, Bacillus subtilis, Enterococcus faecalis, Staphylococcus aureus, Escherichia coli, Klebsiella pneumonia and Pseudomonas aeruginosa).

\section{Experimental}

\section{Materials and methods}

Reagents and solvents were used without further purification, except for triethylamine, which was previously distilled. Microanalyses were performed using a PerkinElmer CHN 2400 micro analyser at the Central Analítica Instituto de Química, USP-São Paulo, Brazil. Melting points were obtained with a Mel-Temp II, Laboratory Devices - USA apparatus and are uncorrected. IR spectra (KBr pellets) were recorded on a FT-IR Spectrum One (Perkin Elmer) spectrophotometer. ${ }^{1} \mathrm{H}$ and ${ }^{13} \mathrm{C}$ NMR spectra were recorded with a Varian Unit Plus $300 \mathrm{MHz}$ spectrometer in dmso- $d_{6}$; coupling constants are reported in Hertz $(\mathrm{Hz})$ and chemical shifts in parts per million (ppm) relative to internal standard $\mathrm{Me}_{4} \mathrm{Si}$. The hydrogen signals were attributed through coupling constant values and ${ }^{1} \mathrm{H} \times{ }^{1} \mathrm{H}-\mathrm{COSY}$ experiments. Electronic spectra were taken on a Diode Array 8452A (Hewlett Packard - HP) spectrophotometer using spectroscopic grade solvents (Tedia Brazil) in $10^{-3}$ and $10^{-4} \mathrm{~mol} \mathrm{~L}^{-1}$ solutions. Electron paramagnetic resonance (EPR) spectra of the frozen copper(II) samples dissolved in dmso at $77 \mathrm{~K}$ were obtained on a Bruker EMX equipment with modulation frequency of $100 \mathrm{kHz}$ operating at about $9.5 \mathrm{GHz}$ (X-band), using quartz tubes accommodated in a quartz Dewar. The EPR parameter values were obtained by 


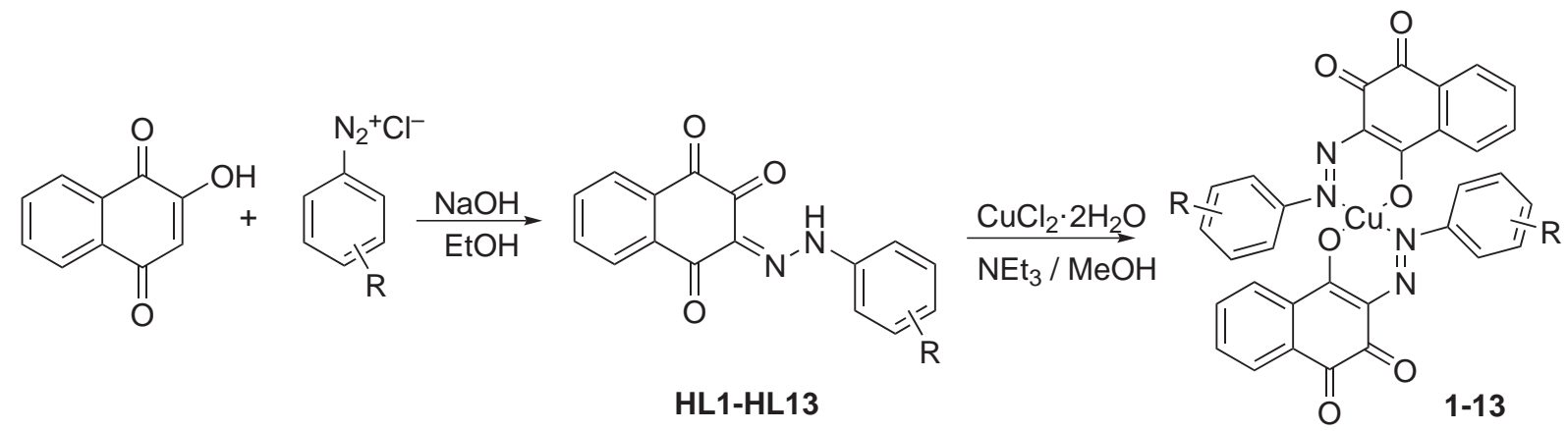

Scheme 1. Synthesis of hydrazono compounds HL1-HL13 and of their respective complexes 1-13; R = 4-OMe, 4-N=NC $\mathrm{H}_{5}$, 4-Cl, 4-I, 3-I, 2-I, 4-COOH,

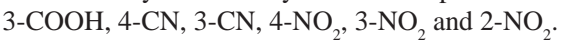

treating and simulating the experimental spectra using the Windows software programs WINEPR and SIMFONIA (Bruker), and the WEAK PITCH BRUKER sample pattern. Cyclic voltammograms were obtained on an Epsilon - BAS potentiostat-galvanostat from $1 \times 10^{-3} \mathrm{~mol} \mathrm{~L}^{-1}$ solutions in dmso containing $0.1 \mathrm{~mol} \mathrm{~L}^{-1}$ of $\left(\mathrm{Bu}_{4} \mathrm{~N}\right) \mathrm{BF}_{4}$ as supporting electrolyte, at room temperature and under argon atmosphere. A standard three component system was used: a carbon-glassy working electrode, a platinum wire auxiliary electrode, and an $\mathrm{Ag} / \mathrm{AgCl}$ reference electrode for organic media. Ferrocene was used as an internal standard $\left(\mathrm{E}_{1 / 2} 0.40 \mathrm{~V} v s\right.$. NHE, normal hydrogen electrode).

Density functional calculations were carried out using the Gaussian03W molecular orbital package. ${ }^{32}$ Geometries were fully optimized using the B3LYP functional ${ }^{33}$ with the standard 6-31G(d) basis set. ${ }^{34}$ The electronic spectra were calculated using the TD (Time Dependent) methodology available in Gaussian with the PBE1PBE functional and the $6-311+G(2 d, p)$ basis set. For calculation of the electronic spectra, solvent effects (dmso) were included by mean of the continuum solvation model using the conductor-like polarisable continuum model ${ }^{35}$ (CPCM). The dielectric constant of dmso, $\varepsilon$, is 46.7. Relative energies are reported at the PBE1PBE/6-311+G(2d,p) level with inclusion of solvent effects.

\section{Synthesis of the hydrazono compounds HL1-HL13}

Compounds HL1-HL13 (Figure 2) were synthesised according to the general procedure described in the literature. ${ }^{26,27,30,31}$ HL1, HL7, HL11, HL12 and HL13 were described previously. ${ }^{26,30}$ See Supplementary Information for description on the synthesis, analytical and spectroscopic data of the novel products.

Synthesis of complexes [Cu(L1- L13 $\left.)_{2}\right]$ from HL1- HL13

To a suspension of $1 \mathrm{mmol}$ of the hydrazono proligand $\mathbf{H L}$ in $30 \mathrm{~mL} \mathrm{MeOH}$, was added a solution of $\mathrm{CuCl}_{2} \cdot 2 \mathrm{H}_{2} \mathrm{O}$ ( $83 \mathrm{mg}, 0.5 \mathrm{mmol}$ ) in $1 \mathrm{~mL} \mathrm{MeOH}$. After addition of $\mathrm{Et}_{3} \mathrm{~N}$ $(0.14 \mathrm{~mL}, 1 \mathrm{mmol})$, the suspension turned into a solution, followed immediately by the formation of a brown solid. The reaction mixture was left under stirring in the dark for $24 \mathrm{~h}$ at room temperature. The resulting solids were filtered off, washed with cold methanol and dried under vacuum. Complexes 1-13 (Figure 3) have not been described previously. See Supplementary Information for analytical and spectroscopic data.

\section{Antibacterial assays}

The antibacterial evaluation was performed with Gram-positive (Bacillus cereus ATCC 33019, Bacillus subtilis ATCC 6633, Enterococcus faecalis ATCC 29212, Staphylococcus aureus ATCC 25923) and Gram-negative (Escherichia coli ATCC 25922, Klebsiella pneumoniae ATCC 700603, Pseudomonas aeruginosa ATCC 27853) bacteria as test-microorganisms, as previously described (see Supplementary Information). ${ }^{15,36,37}$ The tests were performed in triplicate.<smiles>O=c1c(=NNc2ccccc2)c(=O)c2ccccc2c1=O</smiles>

\begin{tabular}{|c|c|c|}
\hline \multirow{6}{*}{\multicolumn{2}{|c|}{$\begin{aligned} & \text { 4-OMe, } \mathbf{H L 1} \\
& 4-\mathrm{N}=\mathrm{N}-\mathrm{C}_{6} \mathrm{H}_{5}, \mathbf{H L 2} \\
\mathrm{R}= & 4-\mathrm{Cl}, \mathbf{H L 3} \\
& 4-\mathrm{I}, \mathbf{H L 4} \\
& \text { 3-I, HL5 } \\
& \text { 2-I, HL6 } \\
& \text { 4-COOH, HL7 }\end{aligned}$}} & \\
\hline & & \\
\hline & & 3-CN HL10 \\
\hline & & 4- $\mathrm{NO}_{2}, \mathrm{HL11}$ \\
\hline & & 3- $\mathrm{NO}_{2}, \mathbf{H L 1 2}$ \\
\hline & & 3 \\
\hline
\end{tabular}

Figure 2. Hydrazono compounds HL1-HL13. 
<smiles>[R][R]1cccc(N=NC2=C(O)c3ccccc3C(=O)C2=O)c1</smiles>

Figure 3. Complexes $\left[\mathrm{Cu}(\mathbf{L} 1-\mathbf{L} 13)_{2}\right]$.

\section{Antitumoral assays}

The compounds (1-5 $\left.\mu \mathrm{g} \mathrm{mL}^{-1}\right)$ were tested for cytotoxic activity against three cancer cell lines: SF-295 (central nervous system), HCT-8 (colon) and MDAMB-435 (breast). All cell lines were maintained in RPMI 1640 medium supplemented with $10 \%$ fetal bovine serum, $2 \mathrm{mmol} \mathrm{L}{ }^{-1}$ glutamine, $100 \mathrm{U} \mathrm{mL}^{-1}$ penicillin, and $100 \mu \mathrm{g} \mathrm{mL}^{-1}$ streptomycin at $37^{\circ} \mathrm{C}$ with $5 \% \mathrm{CO}_{2}$. Each compound was dissolved in dmso and diluted with water to obtain a concentration of $1 \mathrm{mg} \mathrm{mL}^{-1}$. They were incubated with the cells for $72 \mathrm{~h}$. The negative control received the same amount of dmso ( $0.5 \%$ in the highest concentration). Doxorubicin $\left(0.1-0.58 \mu \mathrm{g} \mathrm{mL}^{-1}\right)$ was used as a positive control. The cell viability was determined by reduction of the yellow dye 3-(4,5-dimethyl-2-thiazol)-2,5-phenyl-2Htetrazolium bromide (MTT) to a blue formazan product as described by Mosmann. ${ }^{38}$

\section{Results and Discussion}

\section{Synthesis and characterization of the hydrazono compounds}

Compounds HL1-HL13 (Figure 2) were synthesized from the diazonium salts of the respective arylamines, followed by coupling with lawsone C3 in ethanol under stirring at room temperature. After addition of the diazonium salts to the lausonate solution, the orange products precipitated immediately. Following filtration and washing with cold $\mathrm{EtOH}$, the products were washed with hot acetonitrile, dried under vacuum and obtained in pure form, in yields ranging from 71-92\%. Compounds HL1- HL13 are stable in the solid state and in solution. Their structures were formulated on the basis of analytical and spectroscopic data (see Supplementary Information).

The ${ }^{1} \mathrm{H}$ spectra of compounds HL1-HL13 were obtained in hot dmso- $d_{6}$, due to poor solubility in other solvents. The spectra exhibit characteristic signals attributed to the four hydrogens of the naphthoquinone unit (H5-H8), which

$\mathrm{R}=\begin{array}{ll}4-\mathrm{OMe}, \mathbf{1} & 3-\mathrm{COOH}, \mathbf{8} \\ 4-\mathrm{N}=\mathrm{N}-\mathrm{C}_{6} \mathrm{H}_{5}, \mathbf{2} & 4-\mathrm{CN}, \mathbf{9} \\ 4-\mathrm{Cl}, \mathbf{3} & 3-\mathrm{CN}, \mathbf{1 0} \\ 4-\mathrm{I}, \mathbf{4} & 4-\mathrm{NO}_{2}, \mathbf{1 1} \\ 3-\mathrm{I}, \mathbf{5} & 3-\mathrm{NO}_{2}, \mathbf{1 2} \\ \text { 2-I, } \mathbf{6} & 2-\mathrm{NO}_{2}, \mathbf{1 3} \\ 4-\mathrm{COOH}, \mathbf{7} & \end{array}$

appear in the $\delta 7.5-8.5$ region as dd or bd (H5 and H8) and td (H5 and H7) (see Figure 2 for numbering). The substituted phenylene ring hydrogens appear as broad doublets (substituents in the para position) and multiplets/ triplet (substituents in the metalortho positions); in most cases the naphthoquinone hydrogen signals overlap with those of the arylamine ring, resulting in multiplet signals. Attributions were made on the basis of ${ }^{1} \mathrm{H} \times{ }^{1} \mathrm{H}-\mathrm{COSY}$ experiments, $J$ values and multiplicity. The ${ }^{13} \mathrm{C}$ NMR spectra of the previously reported 2-, 3- and 4- substituted methyl derivatives ${ }^{26}$ have not been described. In the ${ }^{13} \mathrm{C}$ NMR spectra of compounds HL1-HL13 the number of signals does not correspond to the number of the expected carbons, either because of the high relaxation time of some of the carbon nuclei, or due to the poor solubility of the compounds (see Supplementary Information). For this reason tautomerism studies using this technique could not be carried out as described previously for similar systems, ${ }^{25}$ instead, density functional calculations involving relative stability of the possible tautomers and full geometry optimization for the ground state were carried out and are described below.

\section{Theoretical calculations}

Calculation of several tautomers of the unsubstituted derivative, e.g., the enol-azo forms II and III and the alternative keto-hydrazone Ia and Ib forms (Figure 1) showed that Ia and Ib are much more stable than the enol-azo forms IIa (presumably the molecular structure determined by an X-ray diffraction study, see below) and IIb, by at least $14 \mathrm{kcal} \mathrm{mol}^{-1}$ (Table 1). Indeed geometry optimization of the enol-azo tautomer IIb directly converges to the keto-hydrazone form Ib. The two rotamers Ia and Ib are almost isoenergetic, with relative energies in the order or below $0.5 \mathrm{kcal} \mathrm{mol}^{-1}$ (see Supplementary Information for detailed theoretical calculations data). This result is in agreement with those reported on a similar system, viz. 2-arylazo-1-hydroxycyclohex-1-en-3-one. ${ }^{39}$ 
The nature of the substituent in position 4 (electron withdrawing substituents $\mathrm{NO}_{2}$ and $\mathrm{CN}$ versus electron donor $\mathrm{OMe}$ ) does not affect appreciably this stability order (Ib $\cong \mathbf{I a}>>\mathbf{I I})$. This agrees with previous calculations on tautomeric equilibrium for 4-anilino-1,2-naphthoquinones ${ }^{40}$ and is in contrast with the theoretical and experimental results reported for the analogous tautomeric equilibrium of the azo derivatives of 2-naphthol for which electron withdrawing groups were found to strongly stabilize the keto-hydrazone tautomer, whereas electron donor groups shift the equilibrium toward the enol-azo tautomer. ${ }^{25}$

Table 1. Relative energies (PBE1PBE/6-311+G(2d,p), including solvent effect dmso) of tautomers Ia, Ib, IIa and III with different substituents (kcal mol-1)

\begin{tabular}{lcccc}
\hline $\mathrm{R}$ & Ia & Ib & IIa & III \\
\hline $4-\mathrm{OMe}$ & 0.36 & 0.0 & 13.60 & 5.89 \\
$\mathrm{H}$ & 0.23 & 0.0 & 14.39 & 6.98 \\
$4-\mathrm{CN}$ & -0.01 & 0.0 & 14.13 & 7.49 \\
$4-\mathrm{NO}_{2}$ & -0.03 & 0.0 & 14.20 & 7.74 \\
\hline
\end{tabular}

According to the reported X-ray diffraction study of the $\mathrm{R}=3-\mathrm{Me}$ (HL-3-Me) derivative, ${ }^{26}$ this compound exists in the solid state as the enol-azo tautomer IIa (see Figure 1). The authors reported that the molecule occupies two semipopulated sites related by crystallographic inversion centers, and because many atoms coincided, it was necessary to apply bond length constraints to refine the structure. The cif list does not make clear which atoms presented problems (an analysis of the data would be necessary); however, it shows that $\mathrm{C}(1)$ and $\mathrm{H}(14)$ on the one hand, and $\mathrm{C}(4)$ and $\mathrm{N}(2)$ on the other (see Figure 4 for the numbering) have been refined in the same positions. It is possible, therefore, that the $\mathrm{C}(1)-\mathrm{O}(1), \mathrm{C}(4)-\mathrm{O}(4)$ and $\mathrm{N}(1)-\mathrm{N}(2)$ distances reported were influenced by the applied restrictions. Considering that the structure was proposed to be that of tautomer IIa (1,2- rather than a 1,4-naphthoquinone and enol-azo instead of keto-hydrazone) based on C-O, C-N and $\mathrm{N}-\mathrm{N}$ bond length analysis, and that our theoretical calculations indicate that this is the highest energy tautomer of all forms investigated, we propose that the structure of this compound is best described as a mixture of the ketohydrazone tautomers (rotamers Ia and Ib). Unfortunately suitable crystals of HL1-HL13 for an X-ray diffraction study could not be obtained in a variety of solvents and conditions to confirm this proposal.

\section{FTIR spectra}

The FTIR spectra of compounds HL1-HL13 support the proposed structure in the solid state. The broad

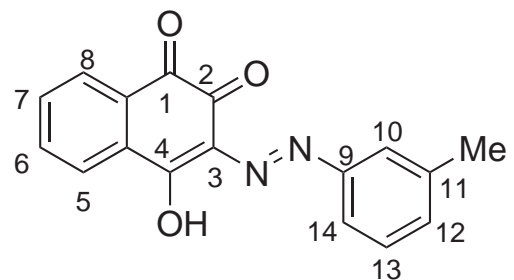

Figure 4. Molecular structure of the 'azo compound' HL-3-Me as previously described. ${ }^{26}$

band around $3450 \mathrm{~cm}^{-1}$, previously attributed to the intramolecular hydrogen bond between $\mathrm{C}(4)$ hydroxyl group and $\mathrm{N}(1)$ of the azo linkage, ${ }^{26}$ may be attributed to intramolecular hydrogen bonded $\mathrm{N}-\mathrm{H}$ stretching present in the two rotamers Ia and $\mathbf{I b},{ }^{41}$ since elemental analyses do not show the presence of water (see Supplementary Information). Calculation of the vibrational spectrum at the B3LYP/6-31G(d) level indicate that $\mathrm{OH}$ stretching in the enol-azo tautomers appears at a much lower wavenumber (around $2830 \mathrm{~cm}^{-1}$ for $\mathrm{R}=\mathrm{H}$ ) than the $\mathrm{NH}$ stretching in the keto-hydrazone forms which appears at about $3300 \mathrm{~cm}^{-1}$ $(\mathrm{R}=\mathrm{H}) .^{41}$ The $\mathrm{v}(\mathrm{C}=\mathrm{O})$ stretches appear as a single band around $1690-1655 \mathrm{~cm}^{-1},{ }^{26}$ as the result of coalescence of the carbonyl bands; in the cases of compounds HL3, HL4 and HL10, in whose spectra this band appears at the lower end of this energy range, an additional $v(\mathrm{C}=\mathrm{O})$ band is observed around $1695 \mathrm{~cm}^{-1}$. The absorption due to $v(\mathrm{~N}=\mathrm{N})$ vibrations, expected at about $1420-1450 \mathrm{~cm}^{-1}$ according to the literature ${ }^{40}$ (calculated $1462 \mathrm{~cm}^{-1}$ ) was not observed, although a very weak band around $970 \mathrm{~cm}^{-1}$ previously attributed to $v(\mathrm{C}-\mathrm{N}=\mathrm{N}-\mathrm{C})$ was observed in the spectra of all compounds and may arise from some tautomerization.

\section{UV-Vis spectra}

The UV-Vis spectra of HL1-HL13, obtained in dmso, show two absorption bands: one very intense in the 257-298 $\mathrm{nm}$ region and a broad low-energy band in the visible region of the spectrum between 459-411 nm. The high intensity of the band in the $257-298 \mathrm{~nm}$ region, attributed to the aromatic and quinone $\pi-\pi^{*}$ transitions, is associated to the high conjugation performed by the arylazo group. The low-energy band is influenced by the nature of the substituent on the phenylene ring, electronreleasing groups $(-\mathrm{OMe})$ shifting it to higher wavelengths (bathochromic shift) and electron-withdrawing groups blue shifting it (hypsochromic effect). Furthermore, substituents in ortho and para positions were found to affect $\lambda_{\text {max }}$ more significantly than groups in the meta position.

The calculated electronic spectra of the most stable tautomers (rotamers Ia and Ib) were obtained using the TDDFT methodology together with the PBE1PBE/6- 
$311+\mathrm{G}(2 \mathrm{~d}, \mathrm{p})$ method. In agreement with the experimental observations, they show two main intense absorption bands due to $\pi \rightarrow \pi^{*}$ transitions (HOMO $\rightarrow$ LUMO and $\mathrm{HOMO} \rightarrow \mathrm{LUMO}+1$ ). HOMO is one of the $\pi$ orbitals of the phenyl ring whereas LUMO and LUMO+1 both are $\pi^{*}$ orbitals of the quinone ring (see Supplementary Information for details of the calculated electronic spectra and illustrations of these orbitals).

\section{Synthesis and characterization of the copper(II) complexes}

The copper(II) complexes of proligands HL1-HL13 were synthesized in order to investigate their antibacterial and antitumor activities, since complexation of the methyl substituted compounds was found to result in increased cytotoxicity. ${ }^{26,27}$

Complexes 1-13 (Figure 3) were obtained by addition of triethylamine to a methanol suspension of HLn $(n=1-13)$ and $\mathrm{CuCl}_{2} \cdot 2 \mathrm{H}_{2} \mathrm{O}(2: 2: 1)$, under stirring at room temperature, for $24 \mathrm{~h}$, in yields varying from 63 to $88 \%$. Elemental analyses confirmed the same formulation, $\left[\mathrm{CuL}_{2}\right]$, as that of the analogous complexes of the 2-, 3- and 4- substituted methyl derivatives (HL-Me) whose structures were established by an X-ray diffraction study of the 3-Me derivative. ${ }^{27}$ Due to low solubility in methanol, acetonitrile and water, conductivity measurements could not be carried out. All compounds were characterized by IR, UV-Vis and EPR spectroscopy (see Supplementary Information).

The FTIR spectra of the complexes are in accordance with those described for the complexes of the HL-Me derivatives. ${ }^{27}$ All spectra exhibit a weak broad absorption band around $3450-3500 \mathrm{~cm}^{-1}$, assigned to the $v(\mathrm{O}-\mathrm{H})$ stretching vibrations of the hydration water molecules in the complexes, whose presence in all samples was confirmed by elemental analyses (see Supplementary Information). As the result of complexation to the oxygen phenolate and the nitrogen bonded to the phenylene ring, two sharp $v(\mathrm{C}=\mathrm{O})$ bands (instead of one in the spectra of most proligands) are observed in the spectra of most complexes, except for compounds 3, 11-13 that exhibit a broad absorption band (Table 2). Absorptions due to $v(\mathrm{~N}=\mathrm{N})$ and $v(\mathrm{C}-\mathrm{N}=\mathrm{N}-\mathrm{C})$ vibrations were not observed in most spectra, due to the apolar nature of these bonds. ${ }^{40}$

The UV-Vis spectra of complexes 1-13 were recorded in dmso and compared to those of their respective proligands. Upon complexation, the low-energy band in the visible region (416-473 $\mathrm{nm}$ ) only shifts slightly, except in the cases of compounds 5, 11, 12 and 13, for which high bathochromic shifts are observed. The band around $257-298 \mathrm{~nm}$ is not altered by coordination. In general, increase in the intensities of the bands of all complexes is
Table 2. Carbonyl absorptions $\left(\mathrm{cm}^{-1}\right)$ of the proligands HL1-HL13 and their copper(II) complexes 1-13

\begin{tabular}{llcl}
\hline Proligand & $v(\mathrm{C}=\mathrm{O})$ & Complexes & $v(\mathrm{C}=\mathrm{O})$ \\
\hline HL1 & 1678 & $\mathbf{1}$ & 1683,1658 \\
HL2 & 1688 & $\mathbf{2}$ & 1685,1663 \\
HL3 & 1669 & $\mathbf{3}$ & $1675(\mathrm{br})$ \\
HL4 & 1663 & $\mathbf{4}$ & 1691,1640 \\
HL5 & 1688 & $\mathbf{5}$ & 1690,1640 \\
HL6 & 1688 & $\mathbf{6}$ & 1690,1640 \\
HL7 & 1689 & $\mathbf{7}$ & 1688,1639 \\
HL8 & 1689 & $\mathbf{8}$ & 1690,1640 \\
HL9 & 1695 & $\mathbf{9}$ & 1689,1650 \\
HL10 & 1655 & $\mathbf{1 0}$ & 1693,1647 \\
HL11 & 1686 & $\mathbf{1 1}$ & $1668(\mathrm{br})$ \\
HL12 & 1675 & $\mathbf{1 2}$ & $1672(\mathrm{br})$ \\
HL13 & 1683 & $\mathbf{1 3}$ & $1675(\mathrm{br})$ \\
\hline
\end{tabular}

observed. The expected charge transfer $\mathrm{L} \rightarrow \mathrm{M}$ band, around $306-370 \mathrm{~nm},{ }^{42}$ is not observed and is possibly masked by the broad energy band of the solvent. Only in the spectra of compounds $2,5,6,7$ and $8\left(10^{-3} \mathrm{~mol} \mathrm{~L}^{-1}\right)$ it was possible to observe a very broad and low intensity band, between $500-600 \mathrm{~nm}$, assigned to $d-d$ transitions of the copper(II) ion. As most complexes are poorly soluble, even in dmso, diffuse reflectance spectra of some of the compounds were obtained (complexes 1, 3, 4, 9, 10, 12, 13), which show a band around $586-637 \mathrm{~nm}$.

The EPR spectra of all compounds exhibit $g_{\|}>g_{\perp}>2$ values, in accordance with approximately square-planar geometry, in some cases with some tetrahedral distortion. The EPR parallel parameters ratio $\left(\mathrm{g}_{\|} / \mathrm{A}_{\|}\right)$has been used as a convenient empirical index of tetrahedral distortion in the $\mathrm{CuL}_{4}$ chromophore units. ${ }^{43}$ This value ranges from ca. 105 to $135 \mathrm{~cm}$ for the square-planar structure, and increases upon increasing tetrahedral distortion. Complexes 3, $\mathbf{4}$ and $\mathbf{1 1}$ have the highest $\mathrm{g}_{\|} / \mathrm{A}_{\|}$ratio values which indicates that these compounds present the weakest ligand field strength in dmso solutions, as expected, due to the presence of electron withdrawing groups in the 4-position (see Supplementary Information for Spin-Hamiltonian parameters).

Cyclic voltammetry studies of HL1-HL13 and complexes 1-13

The redox behavior of compounds HL1-HL13 and their respective complexes 1-13 was evaluated by cyclic voltammetry $(\mathrm{CV})$ at room temperature in $\mathrm{dmso} /\left(\mathrm{Bu}_{4} \mathrm{~N}\right) \mathrm{BF}_{4}$ $\left(0.1 \mathrm{~mol} \mathrm{~L}^{-1}\right)$. The $\mathrm{CVs}$ were obtained in the potential range 
from +1.5 to $-1.8 \mathrm{~V} v s$. $\mathrm{FcH} / \mathrm{FcH}^{+}$(Table 3). For most cases three quasi-reversible pairs of waves were observed for the hydrazono compounds in the negative region of the $\mathrm{CV}$, which is attributed to the electron transfer of the hydrazono forms $\mathbf{I a} / \mathbf{I b}$ and/or process associated to deprotonation of the hydroxyl group in forms IIa/III ${ }^{26}$ (Figure 1). The redox potentials of the naphthoquinone unit are directly influenced by the substituents in the phenylene ring: electron-donor groups present lower $\mathrm{E}_{1 / 2}$ when compared to electron-releasing groups. The complexity of the $\mathrm{CV}$ observed for HL11 and complex 11 indicated that reduction potentials for the nitro group and the naphthoquinone are similar. Upon complexation, the $\mathrm{E}_{1 / 2}(1)$ peak is slightly shifted to more positive potentials.

Table 3. Voltammetric data (V) for HL1-HL13 and 1-13 vs. FcH/FcH ${ }^{+}$

\begin{tabular}{|c|c|c|c|}
\hline Compound & $\mathrm{E}_{1 / 2}(1)$ & $\mathrm{E}_{1 / 2}(2)$ & $E_{1 / 2}(3)$ \\
\hline HL1 & -1.78 & -1.31 & -0.95 \\
\hline 1 & -1.77 & -1.30 & -0.57 \\
\hline HL2 & -1.62 & -1.18 & -0.85 \\
\hline 2 & -1.58 & -1.32 & -1.03 \\
\hline HL3 & -1.72 & -1.23 & -0.86 \\
\hline 3 & -1.71 & -1.22 & -0.85 \\
\hline HL4 & -1.75 & -1.24 & -0.88 \\
\hline 4 & -1.68 & -1.22 & -0.55 \\
\hline HL5 & -1.27 & -0.82 & - \\
\hline 5 & -1.19 & -1.02 & - \\
\hline HL6 & -1.78 & -1.42 & -0.83 \\
\hline 6 & -1.77 & -1.44 & -0.64 \\
\hline HL7 & -1.78 & -1.47 & -0.87 \\
\hline 7 & -1.71 & - & - \\
\hline HL8 & -1.74 & -1.44 & - \\
\hline 8 & -1.69 & - & - \\
\hline HL9 & -1.70 & -1.60 & -1.01 \\
\hline 9 & -1.67 & - & - \\
\hline HL10 & -1.69 & -1.20 & -0.79 \\
\hline 10 & -1.63 & -1.23 & -0.88 \\
\hline HL11 & - & - & - \\
\hline 11 & - & - & - \\
\hline HL12 & -1.84 & -1.63 & -0.78 \\
\hline 12 & -0.67 & - & - \\
\hline HL13 & -1.80 & -0.83 & - \\
\hline 13 & -1.73 & -1.10 & -0.57 \\
\hline
\end{tabular}

\section{Antibacterial activity}

The antibacterial activity of the hydrazono compounds HL1-HL13 and their copper(II) complexes 1-13 was evaluated against seven strains of bacteria: Bacillus cereus (BC), Bacillus subtilis (BS), Escherichia coli (EC), Enterococcus faecalis (EF), Klebsiella pneumoniae (KP), Pseudomonas aeruginosa (PA) and Staphylococcus aureus
(SA). The results show that only compound HL5 exhibited significant activity against three strains of bacteria (BC, BS and EC). It inhibited $\mathrm{EC}$ growth at $20 \mu \mathrm{mol} \mathrm{L} \mathrm{L}^{-1}$, i.e., at lower concentration than the positive control (chloramphenicol, $\left.40-90 \mu \mathrm{mol} \mathrm{L}^{-1}\right)$ and exhibited similar activity $\left(90 \mu \mathrm{mol} \mathrm{L}^{-1}\right)$ to chloramphenicol against BC and BS strains. Furthermore, this compound was far more active against EC than the analogous 3-hydrazino-naphthoquinones derived from 3-diazo-naphthalene-1,2,4-trione. ${ }^{6}$ None of the complexes showed significant antibacterial activity (> $\left.200 \mu \mathrm{mol} \mathrm{L}^{-1}\right)$; furthermore, complex $\mathbf{5}$ was less active than its proligand HL5. Lawsone and $\mathrm{CuCl}_{2} \cdot 2 \mathrm{H}_{2} \mathrm{O}$, tested for comparison, only inhibited bacterial growth at high concentrations (see Supporting Information for detailed antibacterial assay data). Low activity of both proligands and complexes may be associated to their poor solubility and, therefore, low bioavailability. Same behavior was observed for the copper(II) complexes of aminonaphthoquinone Mannich bases derived from lawsone, ${ }^{3}$ and the metal complexes of the anion of 5-amino-8-hydroxy-1,4-naphthoquinone. ${ }^{44}$

\section{Antitumor activity}

The antitumor screening of proligands HL1-HL13 and complexes 1-6, 9, 10, 12 and 13 was initially carried out against three strains of cancer cell lines: SF-295 (central nervous system), HCT-8 (colon) and MDAMB-435 (breast). Doxorubicin (dox) was used as a positive control. Lawsone was also tested for comparison (see Supplementary Information for antitumor activity data). Only the hydrazono compound HL6 exhibited higher growth inhibition of colon cancer cells HCT-8 (96.03\%) than the positive control dox (91.67\%); however, its complex, 6, did not show any significant activity. Complex 13 also exhibited higher antitumor activity (96.03\%) than dox. In four cases (HL2, HL4, HL9 and HL13) complexation resulted in increased antitumor activity against all cancer cell lines. The results indicate, in this system, that the presence of $\mathrm{NO}_{2}$ and I groups in ortho and para positions, respectively, is relevant for the antitumor activity. Due to the high antitumor activity of compounds HL6 and 13, they were selected for $\mathrm{IC}_{50}$ determination against four cancer cell lines: SF-295 (central nervous system), HCT-8 (colon), MDAMB-435 (breast) and HL-60 (leukemia) and the results are presented in Table 4. Compound 13 (Entry 2) shows moderate cytotoxic activity against leukemia cell line.

Interestingly, the most active compound against HL-60 cell line (human leukemia), complex $\mathbf{1 3}\left(\mathrm{R}=2-\mathrm{NO}_{2}\right)$, also presents the lowest EPR parameter $\mathrm{g}_{\|} / \mathrm{A}_{\|}$ratio, i.e., the weakest field ligand (see Supporting Information). The EPR 
Table 4. Cytotoxic activity of compounds HL6 and 13, expressed in $\mathrm{IC}_{50}$, obtained by MTT assay after incubation of cells for $72 \mathrm{~h}$ in the concentrations $0.01-5 \mu \mathrm{g} \mathrm{mL}-1$

\begin{tabular}{lccccc}
\hline Compound & Entry & SF295 & HCT-8 & MDA-MB435 & HL-60 \\
\hline HL6 $(\mathrm{R}=3-\mathrm{I})$ & 1 & $>5$ & $>5$ & $>5$ & $>5$ \\
$\mathbf{1 3}\left(\mathrm{R}=2-\mathrm{NO}_{2}\right)$ & 2 & $>5$ & $>5$ & $>5$ & $4.56(1.66-12.50)$ \\
\hline
\end{tabular}

spectrum of this complex also shows a typical organic free radical line over the perpendicular copper(II) spectrum that is absent in the spectra of complexes $11\left(\mathrm{R}=4-\mathrm{NO}_{2}\right)$ and $12\left(\mathrm{R}=3-\mathrm{NO}_{2}\right)$ and may be responsible for the antitumor activity of complex $\mathbf{1 3}$.

\section{Conclusions}

The predominance of the keto-hydrazone tautomers Ia/Ib, as opposed to the previously reported enol-azo IIb, was confirmed by theoretical calculations that also established that, differently from the analogous 2-naphthol azo system, the nature of the substituent in the phenylene ring does not affect this stability order $(\mathbf{I b} \cong \mathbf{I a}>>$ II). In spite of the higher stability of the keto-hydrazone Ia and Ib forms, deprotonation, followed by reaction with $\mathrm{Cu}^{2+}$, results in the formation of enolate complexes of the azo form IIb.

The antibacterial assays revealed that of all compounds only proligand HL5 $(\mathrm{R}=3-\mathrm{I})$ inhibited the growth of $\mathrm{EC}$ at lower concentration than the positive control (chloramphenicol), thus structure/reduction potentialactivity correlations could not be attempted. In the antitumor screening, in general, complexes were found to be more active than the respective proligands; however, only complex $13\left(\mathrm{R}=2-\mathrm{NO}_{2}\right)$ showed moderate cytotoxic activity against HL-60 cells. Formation of an organic free radical observed in the EPR spectrum of this complex might be responsible for this cytotoxic behaviour.

\section{Supplementary Information}

Supplementary information associated with this paper contains the results of the theoretical calculations, spectroscopic data, NMR spectra $\left({ }^{1} \mathrm{H}\right.$ and $\left.{ }^{13} \mathrm{C}\right), \mathrm{EPR}$, voltammograms, antibacterial and antitumor assay results of compounds HL1-HL13 and the complexes 1-13. These data are available free of charge at http://jbcs.sbq.org.br, as a PDF file.

\section{Acknowledgments}

The authors thank the Brazilian agencies Conselho Nacional de Desenvolvimento Científico e Tecnológico $(\mathrm{CNPq})$ and Fundação de Amparo à Pesquisa do Estado do Rio de Janeiro (FAPERJ) for financial support. Pronex-FAPERJ (grant number E-26/171.512/2006) is acknowledged. J. W. D. C, M. D. V, V. F. F., A. S. M. and L. V. C.-L. are recipients of CNPq research fellowships. A. I. F. and A. C. were benefited with CAPES fellowships and J. P. B. is grateful to FAPERJ for a visitor research fellowship.

\section{References}

1. Nagaoka, K.; Kishi, Y.; Tetrahedron 1981, 37, 3783.

2. Furusaki, A.; Watanabi, T.; Chem. Pharm. Bull. 1973, $21,931$.

3. Neves, A. P.; Barbosa, C. C.; Greco, S. J.; Vargas, M. D.; Visentin, L. C.; Pinheiro, C. B.; Mangrich, A. S.; Barbosa, J. P.; da Costa, G. L.; J. Braz. Chem. Soc. 2009, $20,712$.

4. Tandon, V. K.; Maurya, H. K.; Mishra, N.; Shukla, P. K.; Eur. J. Med. Chem. 2009, 44, 3130.

5. Kim, H.-W.; Lee, C.-H.; Lee, H.-S.; Food. Sci. Biotechnol. 2009 , 18,755 .

6. Oliveira, C. G. T.; Miranda, F. F.; Ferreira, V. F.; Freitas, C. C.; Rabello, R. F.; Carballido, J. M.; Corrêa, L. C. D.; J. Braz. Chem. Soc. 2001, 12, 339.

7. Crosby, I. T.; Rose, M. L.; Collis, M. P.; de Bruyn, P. J.; Keep, P. L. C.; Robertson, A. D.; Aust. J. Chem. 2008, 61, 768.

8. Stagliano, K. W.; Emadi, A.; Lu, Z.; Malinakova, H. C.; Twenter, B.; Yu, M.; Holland, L. E.; Rom, A. M.; Harwood, J. S.; Amin, R.; Johnson, A. A.; Pommier, Y.; Bioorg. Med. Chem. 2006, 14, 5651.

9. Da Silva Junior, E.; de Moura, M. A. B. F.; Pinto, A. V.; Pinto, M. C. F. R.; de Souza, M. C. B. V.; Araujo, A. J.; Pessoa, C.; Costa-Lotufo, L. V.; Montenegro, R. C.; de Moraes, M. O.; Ferreira, V. F.; Goulart, M. O. F.; J. Braz. Chem. Soc. 2009, 20, 635; Tapia, R. A.; Cantuarias, L.; Cuellar, M.; Villena, J.; J. Braz. Chem. Soc. 2009, 20, 999.

10. Pinto, C. N.; Dantas, A. P.; De Moura, K. C. G.; Emery, F. S.; Polequevitch, P. F.; Pinto, M. D.; De Castro, S. L.; Pinto, A. V.; Arzneim. Forsc./Drug Res. 2000, 50, 1120.

11. Goulart, M. O. F.; Zani, C. L.; Tonholo, J.; Freitas, L. R.; de Abreu, F. C.; Oliveira, A. B.; Raslan, D. S.; Starling, S.; Chiari, E.; Bioorg. Med. Chem. Lett. 1997, 7, 2043.

12. Da Silva Junior, E. N.; Menna-Barreto, R. F. S.; Pinto, M. do C. F. R.; Silva, R. S. F.; Teixeira, D. V.; de Souza, M. C. B. V.; de Simone, C. A.; de Castro, S. L.; Ferreira, V. F.; Pinto, A. V.; Eur. J. Med. Chem. 2008, 43, 1774; da Silva Junior, E. N.; de 
Souza, M. C. B. V.; Pinto, A. V.; Pinto, M. do C. F. R.; Goulart, M. O. F.; Barros, F. W. A.; Pessoa, C.; Costa-Lotufo, L. V.; Montenegro, R. C.; de Moraes, M. O.; Ferreira, V. F.; Bioorg. Med. Chem. 2007, 15, 7035.

13. Fry, F. H.; Jacob, C.; Curr. Pharm. Design 2006, 12, 4479; Asche, C.; Mini-Rev. Med. Chem. 2005, 5, 449; Hassani, M.; Cai, W.; Holley, D. C.; Lineswala, J. P.;Maharjan, B. R.; Ebrahimian, G. R.; Seradj, H.; Stocksdale, M. G.; Mohammadi, F.; Marvin, C. C.; Gerdes, J. M.; Beall, H. D.; Behforouz, M.; J. Med. Chem. 2005, 48, 7733; Lee, J. H.; Cheong, J. H.; Park, Y. M.; Choi, Y. H.; Pharmacol. Res. 2005, 51, 553; Liu, K. K. C.; Li, J.; Sakya, S.; Mini-Rev. Med. Chem. 2004, 4, 1105; Kongkathip, N.; Siripong, P.; Sangma, C.; Luangkamin, S.; Niyomdecha, M.; Pattanapa, S.; Piyaviriyalgul, S.; Kongsaeree, P.; Bioorg. Med. Chem. 2003, 11, 3179.

14. Vargas, M. D.; Pinto, A. C.; Echevarria, A.; Esteves-Souza, A.; Camara, C. A.; Cunha, A. C.; Torres, J. C.; Lima, E. L. S.; J. Braz. Chem. Soc. 2006, 17, 439; Esteves-Souza, A.; Figueiredo, D. V.; Esteves, A.; Câmara, C. A.; Vargas, M. D.; Pinto, A. C.; Echevarria, A.; Braz. J. Med. Biol. Res. 2007, 30, 1399; Cunha, A. S.; Vargas, M. D.; Gattass, C. R.; Pinto, A. C.; Camara, C. A.; Esteves, A. S.; Lima, E. L. S.; Oncol. Rep. 2008, $20,225$.

15. Da Silva, A. J. M.; Netto, C. D.; Pacienza-Lima, W.; TorresSantos, E. C.; Rossi-Bergmann, B.; Maurel, S.; Valentin, A.; Costa, P. R. R.; J. Braz. Chem. Soc. 2009, 20, 176.

16. Dos Santos, E. V. M.; Carneiro, J. W. de M.; Ferreira, V. F.; Bioorg. Med. Chem. 2004, 12, 87.

17. Fieser, L. F.; Nazer, M. Z.; Archer, S.; Berberian, D. A.; Slighter, R. G.; J. Med. Chem. 1967, 10, 517.

18. Tandon, V. K.; Maurya, H. K.; Mishra, N. N.; Shukla, P. K.; Eur. J. Med. Chem. 2009, 44, 3130.

19. Macias-Rubalcava, M. L.; Hernandez-Bautista, B. E.; JimenezEstrada, M.; Gonzalez, M. C.; Glenn, A. E.; Hanlin, R. T.; Hernandez-Ortega, S.; Saucedo-Garcia, A.; Muria-Gonzalez, J. M.; Anaya, A. L.; Phytochemistry 2008, 69, 1185.

20. Barbosa, T. P.; Camara, C. A.; Silva, T. M. S.; Martins, R. M.; Pinto, A. C.; Vargas, M. D.; Bioorg. Med. Chem. 2005, 13, 6464; dos Santos, A. F.; Ferraz, P. A. L.; de Abreu, F. C.; Chiari, E.; Goulart, M. O. F.; Sant'Ana, A. E. G.; Planta Med. 2001, 67, 92; Dos Santos, A. F.; Ferraz, P. A. L.; Pinto, A. V.; Pinto, M. C. F. R.; Goulart, M. O. F.; Sant'Ana, A. E. G.; Int. J. Parasitol. 2000, 30, 1199.

21. Kovacic, P.; Becvar, L. E.; Curr. Pharm. Des. 2000, 6, 143; Monks, T. J.; Hanzlik; P.; Cohen, G. M.; Ross, D.; Graham, D. G.; Toxicol. Appl. Pharmacol. 1992, 112, 2.

22. Ferraz, P. A. L.; de Abreu, F. C.; Pinto, A. V.; Glezer, V.; Tonholo, J.; Goulart, M. O. F.; J. Electroanal. Chem. 2001, 507, 275; Kumagai, Y.; Tsurutani, Y.; Shinyashiki, M.; Takeda, S. H.; Nakai, Y.; Yoskikawa, T.; Shimojo, N.; Environ. Toxicol. Pharmacol. 1997, 3, 245.
23. Hsieh, B. R.; Desilets, D.; Kazmaier, P. M.; Dyes Pigm. 1990, 14, 165; Carvalho, C. E. M.; Ferreira, V. F.; Pinto, A. V.; Pinto, M. C. F. R.; Harrison, W.; Dyes Pigm. 2002, 52, 209.

24. Lycka, A.; Jirman, J.; Podstata, J.; Dyes Pigm. 1987, 8, 465.

25. Alarcón, S. H.; Olivieri, A. C.; Sanz, D.; Claramunt, R. M.; Elguero, J.; J. Mol. Struct. 2004, 705, 1.

26. Gokhale, N. H.; Padhye, S. B.; Newton, C.; Pritchard, R.; Metal Based Drugs 2000, 7, 121.

27. Gokhale, N. H.; Shirisha, K.; Padhye, S. B.; Croft, S. L.; Kendrick, H. D.; McKee, V.; Bioorg. Med. Chem. Lett. 2006, 16,430 .

28. Martins, F. T.; Cruz Jr., J. W.; Derogis, P. B. M. C.; dos Santos, M. H.; Veloso, M. P.; Ellena, J.; Doriguetto, A. C.; J. Braz. Chem. Soc. 2007, 18, 1515.

29. Farrera, J.-A.; Canal, I.; Hidalgo-Fernández, P.; PérezGarcía, M. L.; Huertas, O.; Luque, F. J.; Chem. Eur. J. 2008, 14, 2277.

30. Romanyuk, A. L.; Polishchuk, O. P.; Litvin, B. L.; Ganashchak, N. I.; Russ. J. Gen. Chem. 2002, 72, 251.

31. Francisco, A. I.; Casellato, A.; Vargas, M. D.; Org. Prep. Proced. Int. 2009, 41, 323.

32. Frisch, M. J.; Trucks, G. W.; Schlegel, H. B.; Scuseria, G. E.; Robb, M. A.; Cheeseman, J. R.; Montgomery, J. A.; Vreen Jr., T.; Kudin, K. N.; Burat, J. C.; Millam, J. M.; Iyengar, S. S.; Tomsi, J.; Barone, V.; Mennucci, B.; Cossi, M.; Scalmani, G.; Rega, N.; Petersson, G. A.; Nakatsuji, H.; Hada, M.; Ehara, M.; Toyota, K.; Fukua, R.; Hasegawa, J.; Ishida, M.; Nakajim, T.; Honda, Y.; Kitao, O.; Nakai, H.; Klene, M.; Li, X.; Knox, J. E.; Hratchian, H. P.; Cross, J. B.; Adamo, C.; Jaramillo, J.; Gomperts, R.; Stratmann, R. E.; Yazyev, O.; Austin, A. J.; Cammi, R.; Pomelli, C.; Ochteski, J. W.; Ayala, P. Y.; Morokuma, K.; Voth, G. A.; Salvador, P.; Dannenberg, J. J.; Zakrzewski, V. G.; Dapprich, S.; Daniels, A. D.; Strain, M. C.; Faras, O.; Malick, D. K.; Rabu, A. D.; Raghavachari, K.; Foresman, J. B.; Ortiz, J. V.; Cui, Q.; Baboul, A. G.; Clifford, S.; Cioslowski, J.; Stefanov, B. B.; Liu, G.; Liashenko, A.; Piskorz, P.; Komaromi, I.; Martin, R. L.; Fox, D. J.; Keith, T.; Al-Laham, M. A.; Peng, C.; Nanayakkra, A.; Challacombe, M.; Gill, P. M. W.; Johnson, B.; Chen, W.; Wong, M. W.; Gonzalez, C.; Pople, J. A.; Gaussian 03, Revision B.02, Gaussian, Inc.: Pittsburg P. A., 2003.

33. Beck, A. D.; J. Chem. Phys. 1993, 98, 5648.

34. Hariharan, P. C.; Pople, J. A.; Theor. Chim. Acta 1973, 28, 213.

35. Cossi, M.; Rega, N.; Scalmani, G.; Barone, V.; J. Comput. Chem. 2003, 24, 669.

36. Langfield, R. D.; Scarano, F. J.; Heitzman, M. E.; Kondo, M.; Hammond, G. B.; Neto, C. C.; J. Ethnopharmacol. 2004, 94, 279.

37. Eloff, J. N.; Planta Med. 1998, 65, 711.

38. Mosmann, T.; J. Immunol. Methods 1983, 65, 55.

39. Ebeada, Y. H.; Fandya, R. F.; Zayeda, S. E.; Abd-Elshafia, E.; Ibrahimb, S. A.; Can. J. Anal. Spec. 2009, 53, 282. 
40. Fragoso, T. P.; Carneiro, J. W. D.; Vargas, M. D.; J. Mol. Model. 2009, doi: 10.1007/s00894-009-0579-x.

41. Silverstein, R.; Bassaler, G.; Morill, T.; Spectroscopic Identification of Organic Compounds, 5th ed., John Wiley \& Sons Inc.: New York, 2003.

42. Ispir, E.; Dyes Pigm. 2009, 82, 13.
43. Sakaguchi, U.; Addison, A. W.; J. Chem. Soc. Dalton Trans. 1979, 600 .

44. Ma, S.; Zhu, W.; Xu, M.; Wang, Y.; Guo, Q.; Liu, Y.; Polyhedron 2003, 22, 3249.

Received: October 1, 2009 Web Release Date: April 22, 2010 


\title{
Theoretical Studies of the Tautomerism in 3-(2-R-Phenylhydrazono)-naphthalene- 1,2,4-triones: Synthesis of Copper(II) Complexes and Studies of Antibacterial and Antitumor Activities
}

\author{
Acácio I. Francisco, ${ }^{a}$ Maria D. Vargas, ${ }^{*, a}$ Thaís P. Fragoso, ${ }^{a}$ J. Walkimar de M. Carneiro, ${ }^{a}$ \\ Annelise Casellato, ${ }^{b}$ Fernando de C. da Silva, ${ }^{a}$ Vitor F. Ferreira, ${ }^{a}$ Jussara P. Barbosa, ${ }^{c}$ Claudia Pessoa, ${ }^{d}$ \\ Letícia V. Costa-Lotufo, ${ }^{d}$ José D. B. Marinho Filho, ${ }^{d}$ Manoel O. de Moraes ${ }^{d}$ and Antonio S. Mangrich ${ }^{e}$ \\ anstituto de Química, Universidade Federal Fluminense, Campus do Valonguinho, Centro, \\ 24020-150 Niterói-RJ, Brazil \\ ${ }^{b}$ Instituto de Química, Universidade Federal do Rio de Janeiro, Ilha do Fundão, 21945-970 Rio de Janeiro-RJ, Brazil \\ 'Instituto Oswaldo Cruz, FIOCRUZ, CP 926, 21045-900 Rio de Janeiro-RJ, Brazil \\ ${ }^{d}$ Universidade Federal do Ceará, Depto de Fisiologia e Farmacologia, Campus do Porangabussu, \\ 60430-270 Fortaleza-CE, Brazil \\ ${ }^{e}$ Departamento de Química da Universidade Federal do Paraná, 81531-990 Curitiba-PR, Brazil
}

Synthesis and characterization of the hydrazone compounds HL1-HL13

Syntheses

A mixture of the respective arylamine $(6.63 \mathrm{mmol})$, water $(3.5 \mathrm{~mL})$ and concentrated $\mathrm{HCl}(3.5 \mathrm{~mL})$ was stirred until dissolution. The solution was then cooled by addition of crushed ice $(1.00 \mathrm{~g})$. When the temperature reached $0{ }^{\circ} \mathrm{C}, \mathrm{NaNO}_{2}$ (4.39 mmol, $0.303 \mathrm{~g}$ ) in cold water $(2 \mathrm{~mL}$ ) was added to the mixture. The solution was stirred at $0{ }^{\circ} \mathrm{C}$ for $20 \mathrm{~min}$ and then added dropwise to a stirred solution of 2-hydroxy-1,4 naphthoquinone ( $3.65 \mathrm{mmol}, 0.635 \mathrm{~g}$ ) and sodium hydroxide (10.95 mmol, $0.438 \mathrm{~g})$ in ethanol $(28 \mathrm{~mL})$ kept at $0{ }^{\circ} \mathrm{C}$. The resulting orange solids were filtered, washed with cold water and ethanol and dried under vacuum.

Analytical and spectroscopic data for HL1-HL13

3-[2-(4-methoxy)phenylhydrazono]-naphthalene-1,2,4trione (HL1)

From $0.815 \mathrm{~g}$ of 4-methoxyaniline. Yield: $0.922 \mathrm{~g}, 82 \%$, mp 229-230 ${ }^{\circ} \mathrm{C}$. Anal. Calcd. for $\mathrm{C}_{17} \mathrm{H}_{12} \mathrm{~N}_{2} \mathrm{O}_{4}$ : C 66.04; H 4.29; N 8.76\%. Found: C 66.06; H 4.32; N 8.67\%. IR $\left(\mathrm{KBr}, v_{\max } / \mathrm{cm}^{-1}\right): 3435(\mathrm{~N}-\mathrm{H}), 3078(\mathrm{C}-\mathrm{H}$ arom. $), 2847$ (C-H alif.), $1678(\mathrm{C}=\mathrm{O} / \mathrm{C}=\mathrm{N}), 1587(\mathrm{C}=\mathrm{C}), 1260(\mathrm{C}-\mathrm{O})$, $972(\mathrm{C}-\mathrm{N}=\mathrm{N}-\mathrm{C}) .{ }^{1} \mathrm{H}$ NMR (dmso- $\left.d_{6}, 300 \mathrm{MHz}\right): \delta 8.33$ (bd, $J 7.74 \mathrm{~Hz}, 1 \mathrm{H}), 8.21$ (dd, J 7.74, $0.48 \mathrm{~Hz}, 1 \mathrm{H}), 8.06$ (td, $J$

*e-mail: mdvargas@vm.uff.br
7.74, 7.74, $0.48 \mathrm{~Hz}, 1 \mathrm{H}), 7.98(\mathrm{td}, J 7.74,7.74,0.48 \mathrm{~Hz}$, 1H), 7.87 (bd, J $6.42 \mathrm{~Hz}, 2 \mathrm{H}), 7.23$ (bd, J $6.42 \mathrm{~Hz}, 2 \mathrm{H})$, 3.94 (s, 3H). ${ }^{13} \mathrm{C}$ NMR (dmso- $d, 75 \mathrm{MHz}$ ): $\delta 160.0,136.1$, 135.4, 135.1, 134.4, 128.2, 127.9, 120.7, 116.0, 56.3. UVVis [dmso; $\lambda / \mathrm{nm}(\log \varepsilon)]: 276$ (4.51), 473 (3.52).

3-[2-(4-benzoyl)phenylhydrazono]-naphthalene-1,2,4trione (HL2)

From $1.306 \mathrm{~g}$ of 4-aminoazobenzol. Yield: $1.101 \mathrm{~g}$, $79 \%$, mp 290-292 ${ }^{\circ} \mathrm{C}$. Anal. Calcd. for $\mathrm{C}_{22} \mathrm{H}_{14} \mathrm{~N}_{4} \mathrm{O}_{3}: \mathrm{C}$ 69.10; H 3.69; N 14.65\%. Found: C 69.05; H 3.73; N $14.69 \%$. IR $\left(\mathrm{KBr}, \mathrm{v}_{\max } / \mathrm{cm}^{-1}\right): 3439(\mathrm{~N}-\mathrm{H}), 3062,3102(\mathrm{C}-\mathrm{H}$ arom.), $1688(\mathrm{C}=\mathrm{O} / \mathrm{C}=\mathrm{N}), 1590(\mathrm{C}=\mathrm{C}), 1255(\mathrm{C}-\mathrm{O}), 974$ $(\mathrm{C}-\mathrm{N}=\mathrm{N}-\mathrm{C}) .{ }^{1} \mathrm{H}$ NMR (dmso-d, $\left.300 \mathrm{MHz}\right): \delta 8.36$ (bd, $J 7.38 \mathrm{~Hz}, 1 \mathrm{H}), 8.24$ (dd, J 7.38, $1.48 \mathrm{~Hz}, 1 \mathrm{H}), 8.15$ (bd, $J$ 8.85 Hz, 2H), 8.12-7.98 (m, 6H), 7.76-7.67 (m, 3H). ${ }^{13} \mathrm{C}$ NMR (dmso- $\left.d, 75 \mathrm{MHz}\right): \delta 175.8,152.4,150.4,144.1$, 135.4, 131.9, 129.8, 127.5, 124.7, 118.8. UV-Vis [dmso; $\lambda / \mathrm{nm}(\log \varepsilon)]: 257$ (4.73), 459 (3.79).

3-[2-(4-chloro)phenylhydrazono]-naphthalene-1,2,4trione $(\mathrm{HL} 3)$

From $0.842 \mathrm{~g}$ of 4-chloroaniline. Yield: $0.945 \mathrm{~g}, 83 \%$, mp 215-217 ${ }^{\circ} \mathrm{C}$. Anal. Calcd. for $\mathrm{C}_{16} \mathrm{H}_{9} \mathrm{ClN}_{2} \mathrm{O}_{3}$ : C 61.45; H 2.90; N 8.96\%. Found: C 61.65; H 3.10; N 9.07\%. IR $\left(\mathrm{KBr}, v_{\max } / \mathrm{cm}^{-1}\right): 3428(\mathrm{~N}-\mathrm{H}), 3083$ (C-H arom.), 1695 $(\mathrm{C}=\mathrm{O} / \mathrm{C}=\mathrm{N})$ and $1669(\mathrm{C}=\mathrm{O}), 1594(\mathrm{C}=\mathrm{C}), 1255(\mathrm{C}-\mathrm{O})$, $969(\mathrm{C}-\mathrm{N}=\mathrm{N}-\mathrm{C}) .{ }^{1} \mathrm{H}$ NMR (dmso- $\left.d, 300 \mathrm{MHz}\right): \delta 8.34(\mathrm{bd}$, $J 7.28 \mathrm{~Hz}, 1 \mathrm{H}), 8.24(\mathrm{dd}, J 7.28,1.81 \mathrm{~Hz}, 1 \mathrm{H}), 8.07(\mathrm{td}, J$ 7.28, 7.28, $1.81 \mathrm{~Hz}, 1 \mathrm{H}), 8.01(\mathrm{td}, J 7.28,7.28,1.81 \mathrm{~Hz}$, 
1H), 7.92 (bd, J $8.80 \mathrm{~Hz}, 2 \mathrm{H}), 7.69$ (bd, $J 8.80 \mathrm{~Hz}, 2 \mathrm{H})$. ${ }^{13} \mathrm{C}$ NMR (dmso- $\left.d_{6}, 75 \mathrm{MHz}\right): \delta 140.6,135.1,129.7,127.1$, 119.4. UV-Vis [dmso; $\lambda / \mathrm{nm}(\log \varepsilon)]$ : 266 (4.33), 431 (3.48).

\section{3-[2-(4-iodo)phenylhydrazono]-naphthalene-1,2,4-trione (HL4)}

From $1.452 \mathrm{~g}$ of 4-iodoaniline. Yield: $1.179 \mathrm{~g}, 80 \%$, mp 201-202 ${ }^{\circ} \mathrm{C}$. Anal. Calcd. for $\mathrm{C}_{16} \mathrm{H}_{9} \mathrm{IN}_{2} \mathrm{O}_{3}: \mathrm{C} 47.55 ; \mathrm{H}$ 2.24; N 6.93\%. Found: C 47.57; H 2.34; N 7.04\%. IR (KBr, $\left.v_{\max } / \mathrm{cm}^{-1}\right): 3438(\mathrm{~N}-\mathrm{H}), 3084(\mathrm{C}-\mathrm{H}$ arom. $), 1690(\mathrm{C}=\mathrm{O} /$ $\mathrm{C}=\mathrm{N})$ and $1663(\mathrm{C}=\mathrm{O}), 1599(\mathrm{C}=\mathrm{C}), 1257(\mathrm{C}-\mathrm{O}), 969$ $(\mathrm{C}-\mathrm{N}=\mathrm{N}-\mathrm{C}) .{ }^{1} \mathrm{H}$ NMR (dmso- $\left.d_{6}, 300 \mathrm{MHz}\right): \delta 8.32(\mathrm{dd}, J$ $7.31,1.55 \mathrm{~Hz}, 1 \mathrm{H}), 8.22$ (dd, J 7.31, $1.55 \mathrm{~Hz}, 1 \mathrm{H}), 8.10$ 8.02 (m, 2H), 7.97 (bd, J $8.86 \mathrm{~Hz}, 2 \mathrm{H}), 7.69$ (bd, J $8.86 \mathrm{~Hz}$, $2 \mathrm{H}) .{ }^{13} \mathrm{C}$ NMR (dmso- $\left.d, 75 \mathrm{MHz}\right): \delta 175.9,141.9,139.0$, 135.6, 134.7, 133.9, 128.1, 127.7, 120.4. UV-Vis [dmso; $\lambda / \mathrm{nm}(\log \varepsilon)]: 298$ (4.57), 438 (3.61).

\section{3-[2-(3-iodo)phenylhydrazono]-naphthalene-1,2,4-trione} (HL5)

From $1.452 \mathrm{~g}$ of 3-iodoaniline. Yield: $1.135 \mathrm{~g}, 77 \%$, mp 216-218 ${ }^{\circ} \mathrm{C}$. Anal. Calcd. for $\mathrm{C}_{16} \mathrm{H}_{9} \mathrm{IN}_{2} \mathrm{O}_{3}$ : C 47.55; H 2.24; N 6.93\%. Found: C 47.53; H 2.21; N 6.90\%. IR $\left(\mathrm{KBr}, \mathrm{v}_{\max } / \mathrm{cm}^{-1}\right): 3438(\mathrm{~N}-\mathrm{H}), 3087$ (C-H arom.), 1688 $(\mathrm{C}=\mathrm{O} / \mathrm{C}=\mathrm{N}), 1600(\mathrm{C}=\mathrm{C}), 1261(\mathrm{C}-\mathrm{O}), 969(\mathrm{C}-\mathrm{N}=\mathrm{N}-\mathrm{C})$. ${ }^{1} \mathrm{H}$ NMR (dmso- $\left.d, 300 \mathrm{MHz}\right): \delta 8.35(\mathrm{dd}, J 7.35,1.49 \mathrm{~Hz}$, $1 \mathrm{H}), 8.29-8.21(\mathrm{~m}, 2 \mathrm{H}), 8.07(\mathrm{td}, J 7.35,7.35,1.49 \mathrm{~Hz}, 1 \mathrm{H})$, $8.01(\mathrm{td}, J 7.35,7.35,1.49 \mathrm{~Hz}, 1 \mathrm{H}), 7.90(\mathrm{dd}, J 7.35,1.57$ $\mathrm{Hz}, 1 \mathrm{H}), 7.79(\mathrm{dl}, J 7.35 \mathrm{~Hz}, 1 \mathrm{H}), 7.42(\mathrm{bt}, J 7.35 \mathrm{~Hz}, 1 \mathrm{H})$. ${ }^{13} \mathrm{C}$ NMR (dmso- $\left.d_{6}, 75 \mathrm{MHz}\right): \delta 175.3,142.7,135.4,134.4$, 135.0, 131.5, 127.1, 125.7, 117.2, 95.2. UV-Vis [dmso; $\lambda / \mathrm{nm}(\log \varepsilon)]: 270$ (4.61), 425 (3.32).

\section{3-[2-(2-iodo)phenylhydrazono]-naphthalene-1,2,4-trione} (HL6)

From $1.452 \mathrm{~g}$ of 2-iodoaniline. Yield: $1.297 \mathrm{~g}, 88 \%$, mp 230-232 ${ }^{\circ} \mathrm{C}$. Anal. Calcd. for $\mathrm{C}_{16} \mathrm{H}_{9} \mathrm{IN}_{2} \mathrm{O}_{3}$ : C 47.55; H 2.24; N 6.93\%. Found: C 47.55; H 2.24; N 6.93\%. IR $\left(\mathrm{KBr}, \mathrm{v}_{\max } / \mathrm{cm}^{-1}\right): 3438(\mathrm{~N}-\mathrm{H}), 3087$ (C-H arom.), 1688 $(\mathrm{C}=\mathrm{O} / \mathrm{C}=\mathrm{N}), 1601(\mathrm{C}=\mathrm{C}), 1259(\mathrm{C}-\mathrm{O}), 969(\mathrm{C}-\mathrm{N}=\mathrm{N}-\mathrm{C})$. ${ }^{1} \mathrm{H}$ NMR (dmso- $\left.d_{6}, 300 \mathrm{MHz}\right): \delta 8.37$ (bd, $\left.J 7.33 \mathrm{~Hz}, 1 \mathrm{H}\right)$, 8.26 (bd, $J 7.33 \mathrm{~Hz}, 1 \mathrm{H}), 8.12-7.91$ (m, 4H), 7.70 (bt, $J 7.63$ $\mathrm{Hz}, 1 \mathrm{H}), 7.23$ (bt, $J 7.63 \mathrm{~Hz}, 1 \mathrm{H}) .{ }^{13} \mathrm{C}$ NMR (dmso-d $d_{6}, 75$ $\mathrm{MHz}): \delta 178.9,141.5,139.6,135.0,134.5,134.0,133.4$, 133.1, 132.5, 129.9, 128.6, 127.7, 127.2, 117.6, 117.4, 87.5. UV-Vis [dmso; $\lambda / \mathrm{nm}(\log \varepsilon)]: 276$ (4.44), 434 (3.33).

3-[2-(4-carboxy)phenylhydrazono]-naphthalene-1,2,4trione $(\mathrm{HL}$ 7)

From $0.908 \mathrm{~g}$ of 4-carboxyaniline. Yield: $1.046 \mathrm{~g}, 89 \%$, mp 235-237 ${ }^{\circ} \mathrm{C}$. Anal. Calcd. for $\mathrm{C}_{17} \mathrm{H}_{10} \mathrm{~N}_{2} \mathrm{O}_{5}$ : C 62.66;
H 3.22; N 8.65\%. Found: C 62.55; H 3.25; N 8.67\%. IR $\left(\mathrm{KBr}, \nu_{\max } / \mathrm{cm}^{-1}\right): 3451-2700(\mathrm{O}-\mathrm{H} \mathrm{COOH} / \mathrm{N}-\mathrm{H}), 3068(\mathrm{C}-\mathrm{H}$ arom.), $1689(\mathrm{C}=\mathrm{O} / \mathrm{C}=\mathrm{N}), 1598(\mathrm{C}=\mathrm{C}), 1263(\mathrm{C}-\mathrm{O}), 968$ $(\mathrm{C}-\mathrm{N}=\mathrm{N}-\mathrm{C}) .{ }^{1} \mathrm{H}$ NMR (dmso- $\left.d_{6}, 300 \mathrm{MHz}\right): \delta 8.35$ (bd, $J$ $8.41 \mathrm{~Hz}, 1 \mathrm{H}), 8.24$ (dd, $J 8.41,1.53 \mathrm{~Hz}, 1 \mathrm{H}), 8.17$ (bd, $J$ $7.44 \mathrm{~Hz}, 2 \mathrm{H}), 8.08(\mathrm{td}, J 8.41,8.41,1.53 \mathrm{~Hz}, 1 \mathrm{H}), 8.02(\mathrm{td}$, $J$ 8.41, 8.41, $1.53 \mathrm{~Hz}, 1 \mathrm{H}), 7.96$ (bd, $J 7.44 \mathrm{~Hz}, 2 \mathrm{H}) .{ }^{13} \mathrm{C}$ NMR (dmso- $\left.d_{6}, 75 \mathrm{MHz}\right): \delta 175.5,166.5,144.8,135.0$, 131.0, 128.6, 127.1, 117.4. UV-Vis [dmso; $\lambda / \mathrm{nm}(\log \varepsilon)]$ : 277 (4.49), 424 (3.67).

3-[2-(3-carboxy)phenylhydrazono]-naphthalene-1,2,4trione $(\boldsymbol{H L} \boldsymbol{L})$

From $0.908 \mathrm{~g}$ of 3-carboxyaniline. Yield: $0.834 \mathrm{~g}, 71 \%$, mp 270-272 ${ }^{\circ} \mathrm{C}$. Anal. Calcd. for $\mathrm{C}_{17} \mathrm{H}_{10} \mathrm{~N}_{2} \mathrm{O}_{5}: \mathrm{C}$ 62.66; H 3.22; N 8.65\%. Found: C 62.67; H 3.20; N 8.64\%. IR $\left(\mathrm{KBr}, \nu_{\max } / \mathrm{cm}^{-1}\right): 3449-2600(\mathrm{O}-\mathrm{H} \mathrm{COOH} / \mathrm{N}-\mathrm{H}), 3051(\mathrm{C}-\mathrm{H}$ arom.), $1689(\mathrm{C}=\mathrm{O} / \mathrm{C}=\mathrm{N}), 1605(\mathrm{C}=\mathrm{C}), 1251(\mathrm{C}-\mathrm{O}), 968$ $(\mathrm{C}-\mathrm{N}=\mathrm{N}-\mathrm{C}) .{ }^{1} \mathrm{H}$ NMR (dmso- $\left.d_{6}, 300 \mathrm{MHz}\right): \delta 8.36(\mathrm{~m}$, $1 \mathrm{H}), 8.31$ (dd, $J 7.42,1.45 \mathrm{~Hz}, 1 \mathrm{H}), 8.13$ (dd, $J 7.42,1.45$ $\mathrm{Hz}, 1 \mathrm{H}), 8.05-7.95(\mathrm{~m}, 3 \mathrm{H}), 7.90$ (td, $J$ 7.42, 7.42, 1.45 $\mathrm{Hz}, 1 \mathrm{H}), 7.71$ (bt, $J 7.51 \mathrm{~Hz}, 1 \mathrm{H}) .{ }^{13} \mathrm{C}$ NMR (dmso- $d_{6}, 75$ MHz): $\delta$ 179.1, 172.0, 167.7, 147.8, 135.4, 134.0, 133.5, 133.1, 130.0, 128.3, 127.4, 127.2, 124.0, 120.0. UV-Vis [dmso; $\lambda / \mathrm{nm}(\log \varepsilon)]: 271$ (4.63), 441 (3.63).

3-[2-(4-ciano)phenylhydrazono]-naphthalene-1,2,4-trione (HL9)

From $0.782 \mathrm{~g}$ of 4-cianoaniline. Yield: $0.929 \mathrm{~g}, 84 \%, \mathrm{mp}$ 255-259 ${ }^{\circ} \mathrm{C}$. Anal. Calcd. for $\mathrm{C}_{17} \mathrm{H}_{9} \mathrm{~N}_{3} \mathrm{O}_{3}: \mathrm{C} 67.33 ; \mathrm{H} 2.99$; $\mathrm{N} 13.86 \%$. Found: C 67.69; H 3.01; N 13.88\%. IR (KBr, $\left.v_{\max } / \mathrm{cm}^{-1}\right): 3426(\mathrm{~N}-\mathrm{H}), 3070(\mathrm{C}-\mathrm{H}$ arom.), $2220(\mathrm{CN}), 1695$ $(\mathrm{C}=\mathrm{O} / \mathrm{C}=\mathrm{N}), 1607(\mathrm{C}=\mathrm{C}), 1260(\mathrm{C}-\mathrm{O}), 967(\mathrm{C}-\mathrm{N}=\mathrm{N}-\mathrm{C})$. ${ }^{1} \mathrm{H}$ NMR (dmso- $d$, $\left.300 \mathrm{MHz}\right): \delta 8.34(\mathrm{dd}, J 6.93,1.65 \mathrm{~Hz}$, $1 \mathrm{H}), 8.24$ (dd, $J$ 6.93, $1.65 \mathrm{~Hz}, 1 \mathrm{H}), 8.10-7.99$ (m, 6H). ${ }^{13} \mathrm{C}$ NMR (dmso- $\left.d_{6}, 75 \mathrm{MHz}\right): \delta 179.4,176.0,135.6,134.8$, 134.4, 128.0, 127.7, 119.1, 118.6, 108.7. UV-Vis [dmso; $\lambda / \mathrm{nm}$ (log $\varepsilon)]: 282$ (4.77), 425 (3.42).

3-[2-(3-ciano)phenylhydrazono]-naphthalene-1,2,4-trione (HL10)

From $0.782 \mathrm{~g}$ of 3-cianoaniline. Yield: $0.818 \mathrm{~g}, 74 \%, \mathrm{mp}$ 280-281 ${ }^{\circ} \mathrm{C}$. Anal. Calcd. for $\mathrm{C}_{17} \mathrm{H}_{9} \mathrm{~N}_{3} \mathrm{O}_{3}: \mathrm{C} 67.33 ; \mathrm{H} 2.99$; N 13.86\%. Found: C 67.30; H 2.96; N 13.87\%. IR (KBr, $\left.v_{\max } / \mathrm{cm}^{-1}\right): 3431(\mathrm{~N}-\mathrm{H}), 3080$ (C-H arom.), $2231(\mathrm{CN}), 1692$ $(\mathrm{C}=\mathrm{O} / \mathrm{C}=\mathrm{N})$ and $1655(\mathrm{C}=\mathrm{O}), 1600(\mathrm{C}=\mathrm{C}), 1261(\mathrm{C}-\mathrm{O}), 972$ $(\mathrm{C}-\mathrm{N}=\mathrm{N}-\mathrm{C}) .{ }^{1} \mathrm{H}$ NMR (dmso- $\left.d_{6}, 300 \mathrm{MHz}\right): \delta 8.38-8.17$ $(\mathrm{m}, 4 \mathrm{H}), 8.12-7.98(\mathrm{~m}, 2 \mathrm{H}), 7.90-7.80(\mathrm{~m}, 2 \mathrm{H}) .{ }^{13} \mathrm{C} \mathrm{NMR}$ (dmso- $\left.d_{6}, 75 \mathrm{MHz}\right): \delta 179.3,176.1,143.2,135.7,135.3$, 134.3, 131.7, 130.5, 128.4, 127.8, 122.5, 121.6, 118.9, 113.1. UV-Vis [dmso; $\lambda / \mathrm{nm}(\log \varepsilon)]$ : 278 (4.63), 417 (3.41). 
3-[2-(4-nitro)phenylhydrazono]-naphthalene-1,2,4-trione (HL11)

From $0.915 \mathrm{~g}$ of 4-nitroaniline. Yield: $1.084 \mathrm{~g}, 92 \%, \mathrm{mp}$ 275-276 ${ }^{\circ} \mathrm{C}$. Anal. Calcd. for $\mathrm{C}_{16} \mathrm{H}_{9} \mathrm{~N}_{3} \mathrm{O}_{5}: \mathrm{C} 59.45 ; \mathrm{H} 2.81 ; \mathrm{N}$ 13.00\%. Found:C59.33; H2.87; N13.05\%. IR $\left(\mathrm{KBr}, \mathrm{v}_{\max } / \mathrm{cm}^{-1}\right)$ : $3452(\mathrm{~N}-\mathrm{H}), 3084(\mathrm{C}-\mathrm{H}$ arom.), $1686(\mathrm{C}=\mathrm{O} / \mathrm{C}=\mathrm{N})$, 1512 and $1316\left(\mathrm{NO}_{2}\right), 1264(\mathrm{C}-\mathrm{O}), 968(\mathrm{C}-\mathrm{N}=\mathrm{N}-\mathrm{C}) .{ }^{1} \mathrm{H}$ NMR (dmso- $\left.d_{6}, 300 \mathrm{MHz}\right): \delta 8.48$ (bd, $\left.J 8.51 \mathrm{~Hz}, 2 \mathrm{H}\right), 8.34$ (dd, J 7.07, $1.64 \mathrm{~Hz}, 1 \mathrm{H}), 8.25(\mathrm{dd}, J 7.07,1.64 \mathrm{~Hz}, 1 \mathrm{H})$, 8.11-7.99 (m, 4H). ${ }^{13} \mathrm{C}$ NMR (dmso- $\left.d_{6}, 75 \mathrm{MHz}\right): \delta 184.1$, 181.1, 152.5, 150.1, 140.4, 139.0, 133.0, 132.7, 131.1, 123.2. UV-Vis [dmso; $\lambda / \mathrm{nm}(\log \varepsilon)$ ]: 290 (4.55), 429 (3.71).

\section{3-[2-(3-nitro)phenylhydrazono]-naphthalene-1,2,4-trione (HL12)}

From $0.915 \mathrm{~g}$ of 3-nitroaniline. Yield: $0.955 \mathrm{~g}, 81 \%$, mp 167-168 ${ }^{\circ} \mathrm{C}$. Anal. Calcd. for $\mathrm{C}_{16} \mathrm{H}_{9} \mathrm{~N}_{3} \mathrm{O}_{5}: \mathrm{C} 59.45 ; \mathrm{H}$ 2.81 ; N 13.00\%. Found: C 59.28; H 2.97; N 12.99\%. IR $\left(\mathrm{KBr}, v_{\max } / \mathrm{cm}^{-1}\right): 3445(\mathrm{~N}-\mathrm{H}), 3090(\mathrm{C}-\mathrm{H}$ arom.), 1675 $(\mathrm{C}=\mathrm{O} / \mathrm{C}=\mathrm{N}), 1496$ and $1315\left(\mathrm{NO}_{2}\right), 1261(\mathrm{C}-\mathrm{O}), 973$ $(\mathrm{C}-\mathrm{N}=\mathrm{N}-\mathrm{C}) .{ }^{1} \mathrm{H}$ NMR (dmso- $\left.d_{6}, 300 \mathrm{MHz}\right): \delta 8.71(\mathrm{~m}$, 1H), 8.35 (dd, J 7.97, $1.93 \mathrm{~Hz}, 1 \mathrm{H}), 8.31$ (dd, J 7.97, 1.93
$\mathrm{Hz}, 1 \mathrm{H}), 8.22$ (m, 2H), 8.07 (td, J 7.97, 7.97, $1.93 \mathrm{~Hz}, 1 \mathrm{H})$, 8.01 (td, J 7.97, 7.97, $1.93 \mathrm{~Hz}, 1 \mathrm{H}), 7.90(\mathrm{bt}, 7.54 \mathrm{~Hz}, 1 \mathrm{H})$. ${ }^{13} \mathrm{C}$ NMR (dmso- $\left.d_{6}, 75 \mathrm{MHz}\right): \delta$ 184.1, 181.1, 153.7, 150.0, 141.2, 133.7, 131.3, 123.5. UV-Vis [dmso; $\lambda / \mathrm{nm}(\log \varepsilon)]$ : 293 (4.57), 416 (3.68).

\section{3-[2-(2-nitro)phenylhydrazono]-naphthalene-1,2,4-trione} (HL13)

From $0.915 \mathrm{~g}$ of 2-nitroaniline. Yield: $1.297 \mathrm{~g}, 78 \%$, mp 249-250 ${ }^{\circ} \mathrm{C}$. Anal. Calcd. for $\mathrm{C}_{16} \mathrm{H}_{9} \mathrm{~N}_{3} \mathrm{O}_{5}$ : C 59.45; $\mathrm{H}$ $2.81 ; \mathrm{N} 13.00 \%$. Found: C 59.52; H 2.89; N $12.95 \%$. IR $\left(\mathrm{KBr}, v_{\max } / \mathrm{cm}^{-1}\right): 3455(\mathrm{~N}-\mathrm{H}), 3090(\mathrm{C}-\mathrm{H}$ arom.), 1683 $(\mathrm{C}=\mathrm{O} / \mathrm{C}=\mathrm{N}), 1600(\mathrm{C}=\mathrm{C}), 1457$ and $1332\left(\mathrm{NO}_{2}\right), 1271(\mathrm{C}-$ O), 982 (C-N=N-C). ${ }^{1} \mathrm{H}$ NMR (dmso- $d_{6}, 300 \mathrm{MHz}$ ): $\delta 8.37$ (bd, J7.33 Hz, 1H), 8.26 (bd, J 7.33 Hz, 1H), 8.12-7.91 (m, 4H), 7.70 (bt, $J 7.63 \mathrm{~Hz}, 1 \mathrm{H}), 7.23$ (bt, $J 7.63 \mathrm{~Hz}, 1 \mathrm{H}) .{ }^{13} \mathrm{C}$ NMR (dmso- $\left.d_{6}, 75 \mathrm{MHz}\right): \delta$ 178.9, 141.5, 139.6, 135.0, 134.5, 134.0, 133.4, 133.1, 132.5, 129.9, 128.6, 127.7, 127.2, 117.6, 117.4, 87.5. UV-Vis [dmso; $\lambda / \mathrm{nm}(\log \varepsilon)]$ : 278 (4.52), 440 (3.74).

${ }^{1} \mathrm{H}$ and ${ }^{13} \mathrm{C}$ NMR spectra of compounds $\mathrm{HL1}-\mathrm{HL13}$
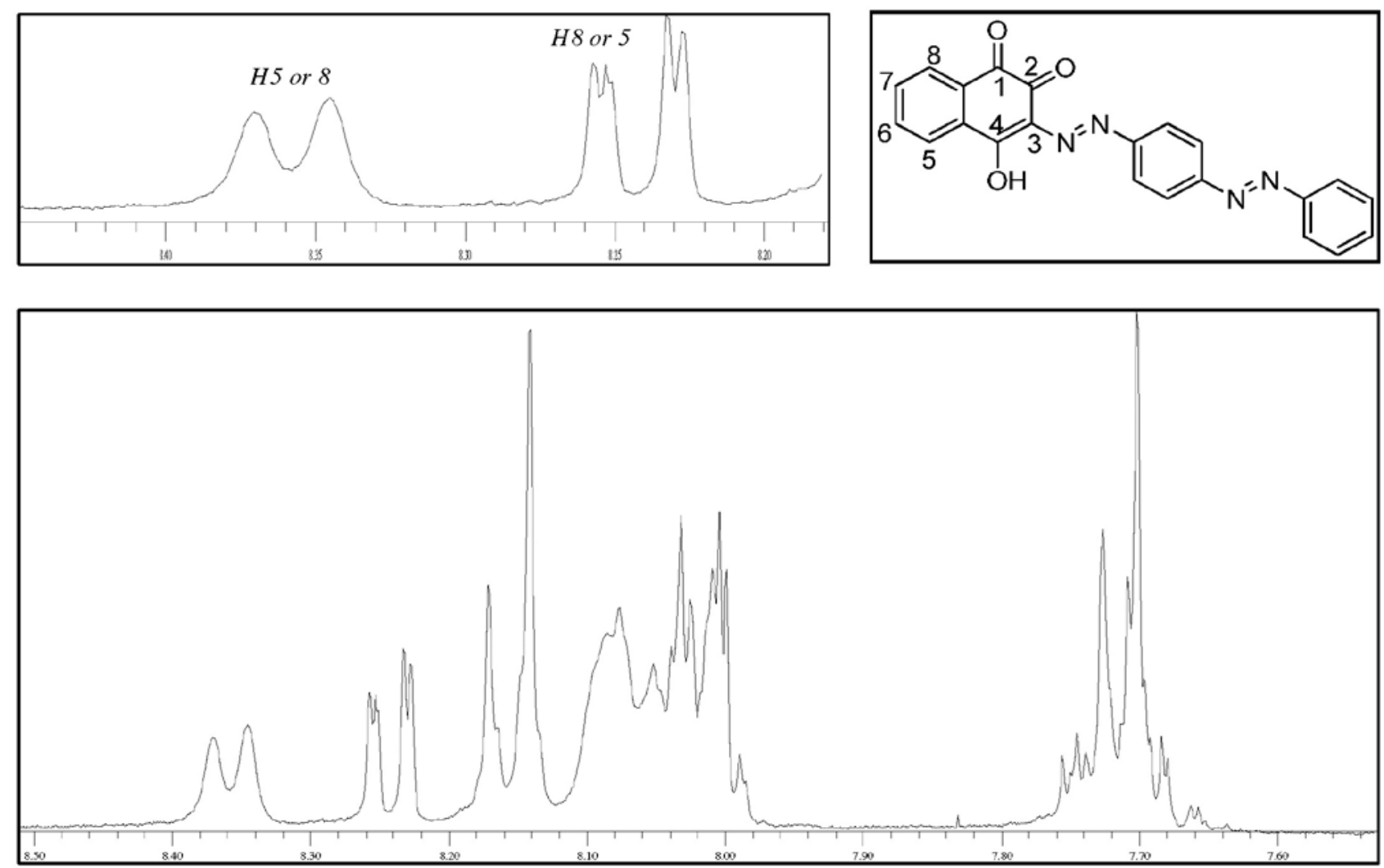

Figure S1. 'H NMR spectrum of 3-[2-(4-benzoyl)phenylhydrazono]-naphthalene-1,2,4-trione (HL2). 


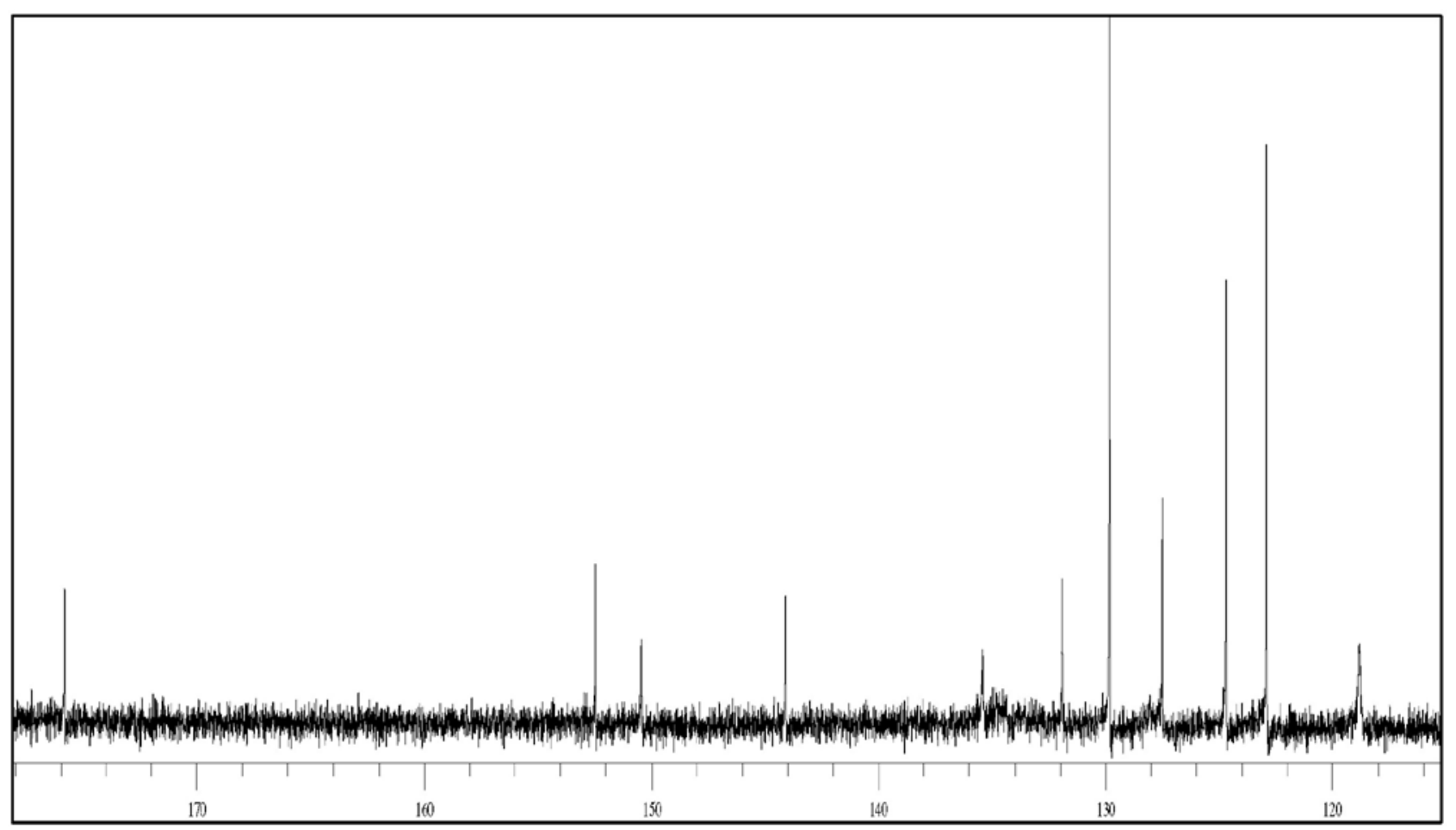

Figure S2. ${ }^{13} \mathrm{C}$ NMR spectrum of 3-[2-(4-benzoyl)phenylhydrazono]-naphthalene-1,2,4-trione (HL2).
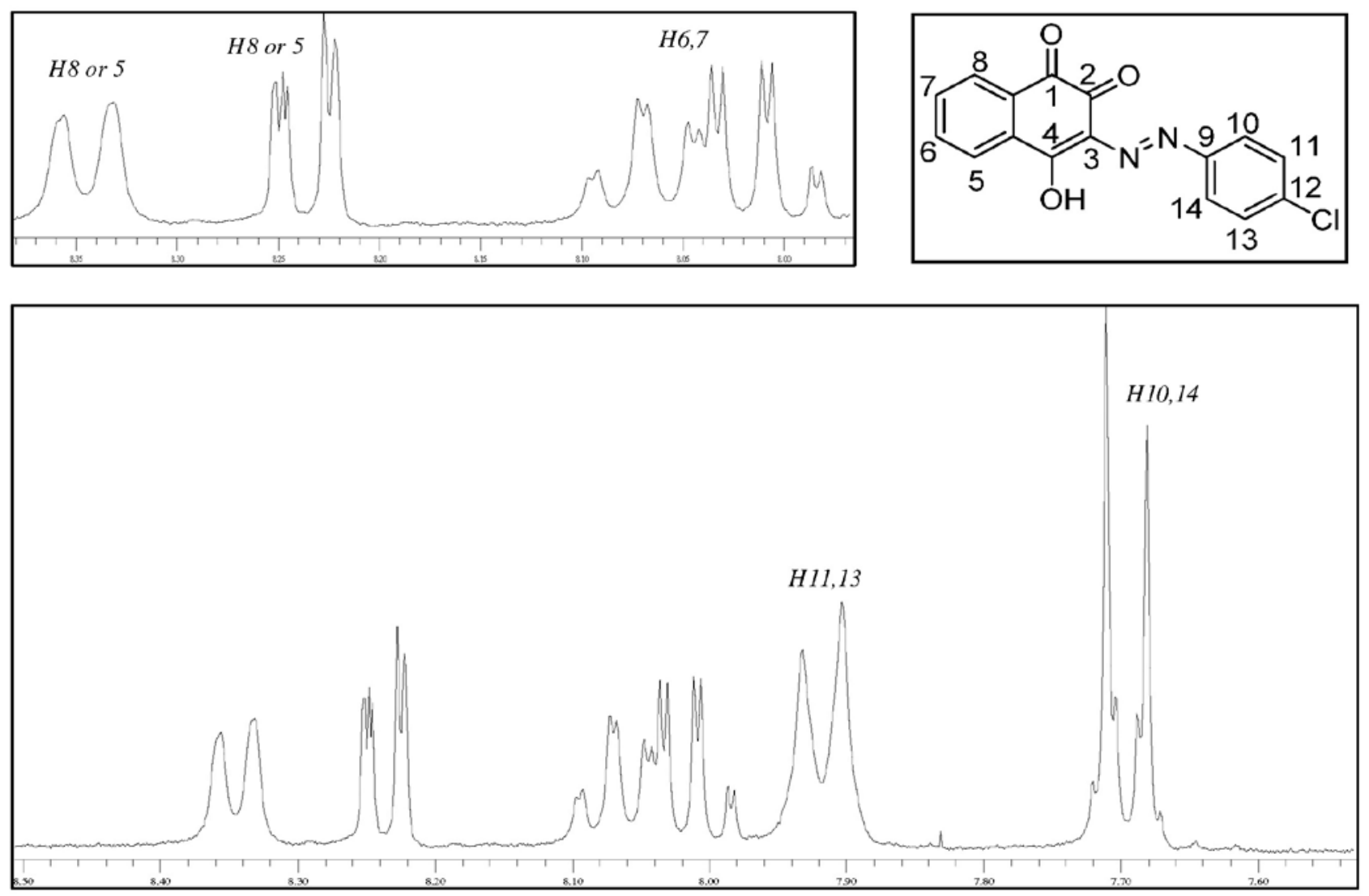

Figure S3. ${ }^{1} \mathrm{H}$ NMR spectrum of 3-[2-(4-chloro)phenylhydrazono]-naphthalene-1,2,4-trione (HL3). 


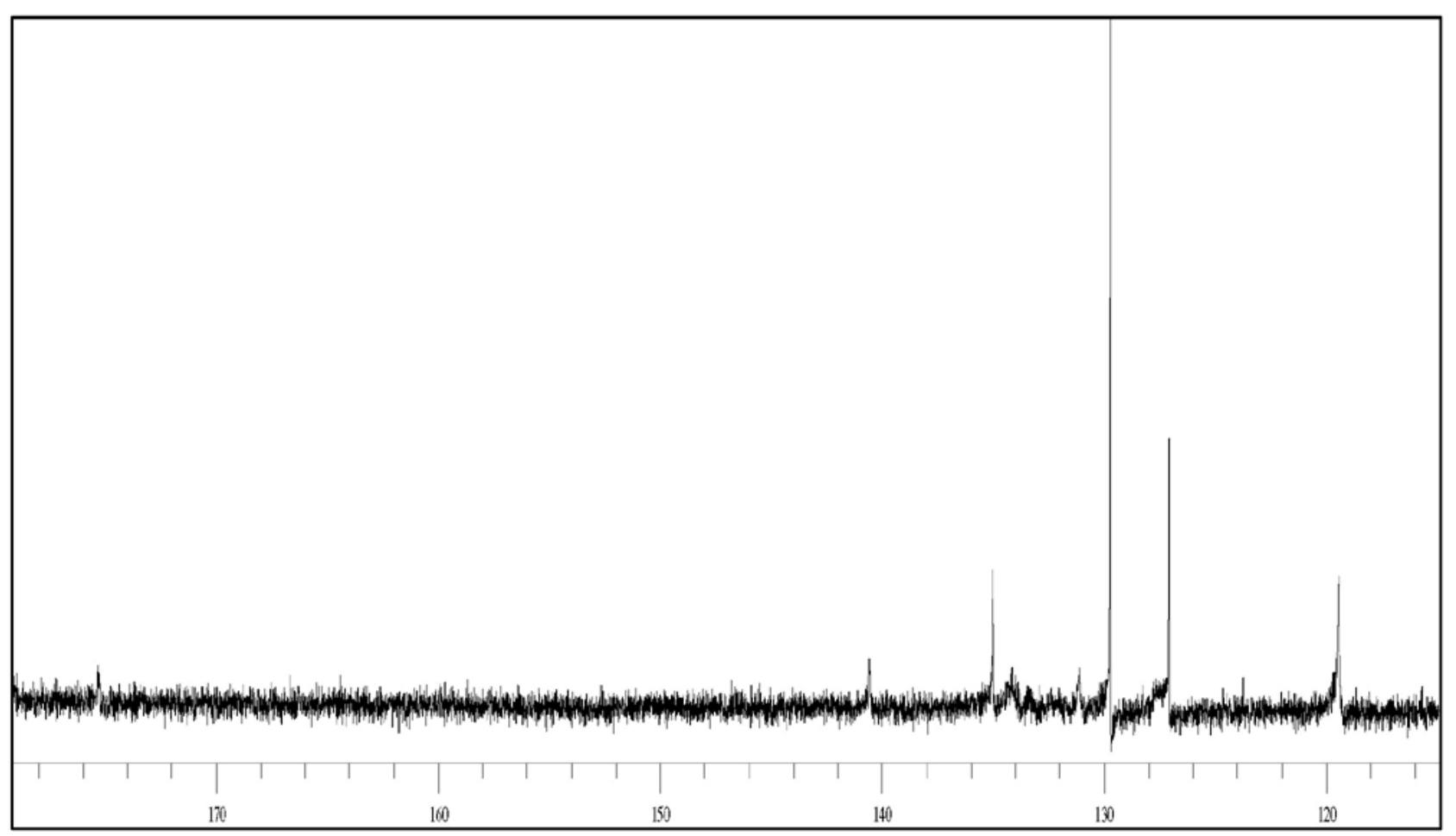

Figure S4. ${ }^{13} \mathrm{C}$ NMR spectrum of 3-[2-(4-chloro)phenylhydrazono]-naphthalene-1,2,4-trione (HL3).
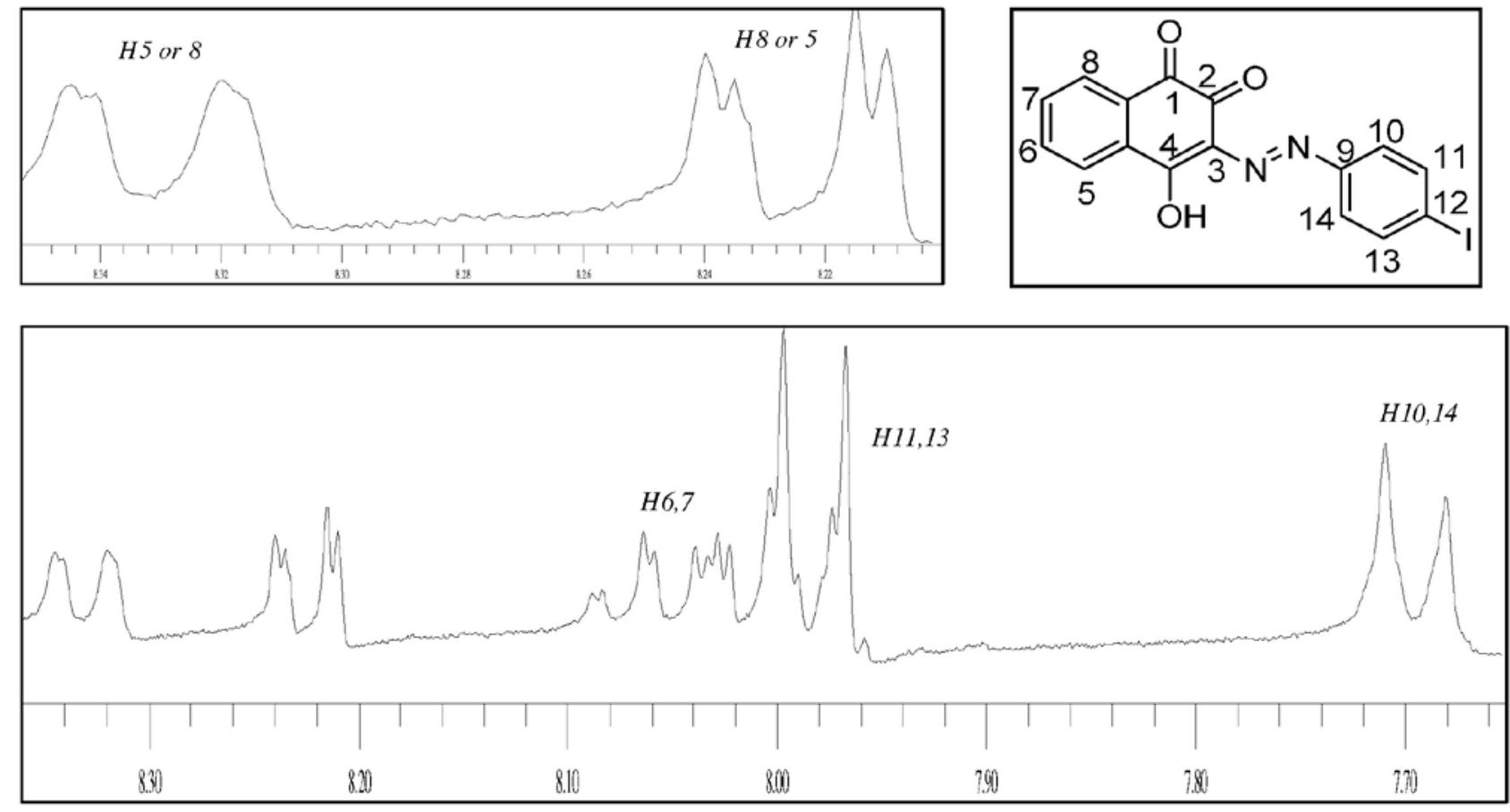

Figure S5. ${ }^{1} \mathrm{H}$ NMR spectrum of 3-[2-(4-iodo)phenylhydrazono]-naphthalene-1,2,4-trione (HL4). 


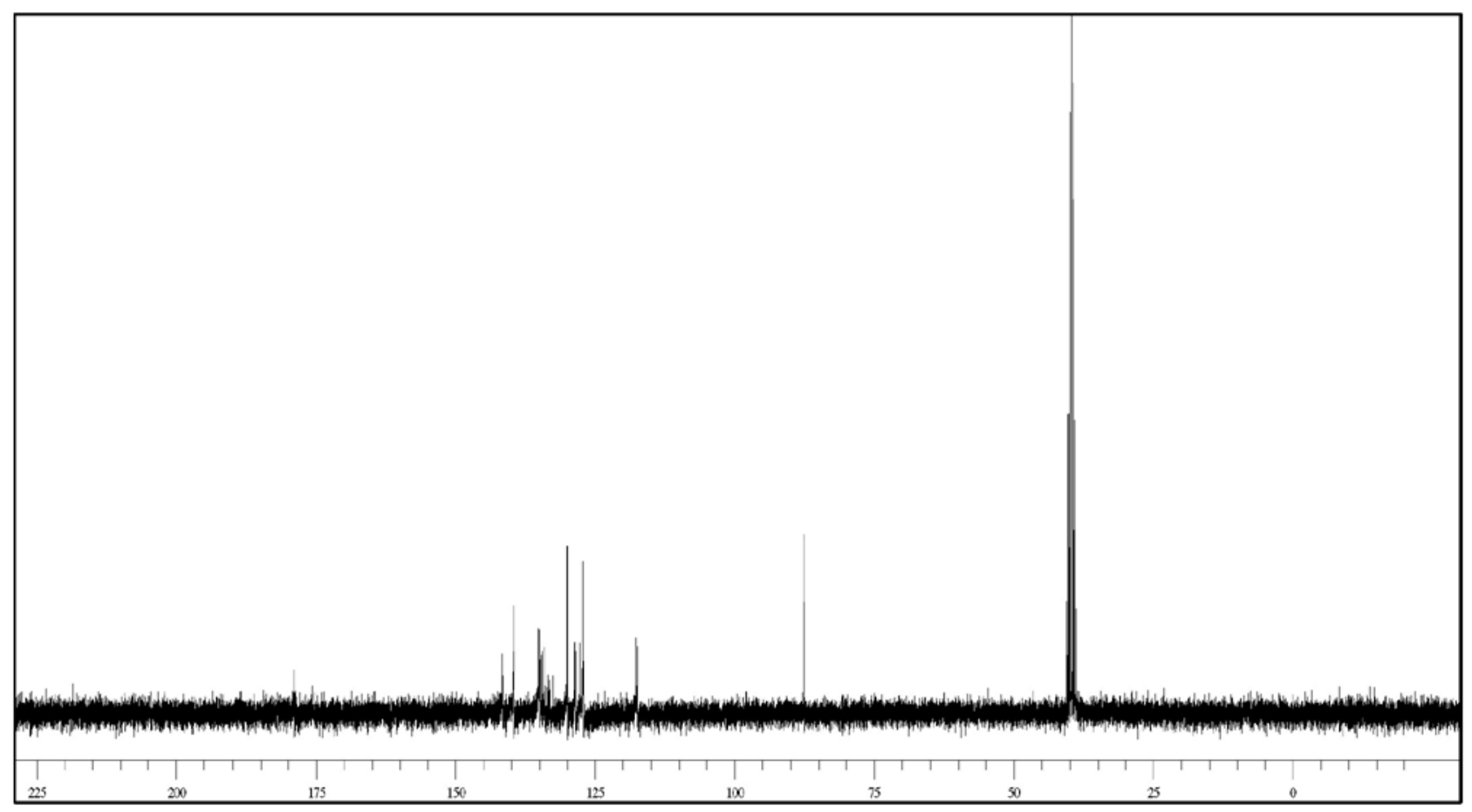

Figure S6. ${ }^{13} \mathrm{C}$ NMR spectra of 3-[2-(4-iodo)phenylhydrazono]-naphthalene-1,2,4-trione (HL4).
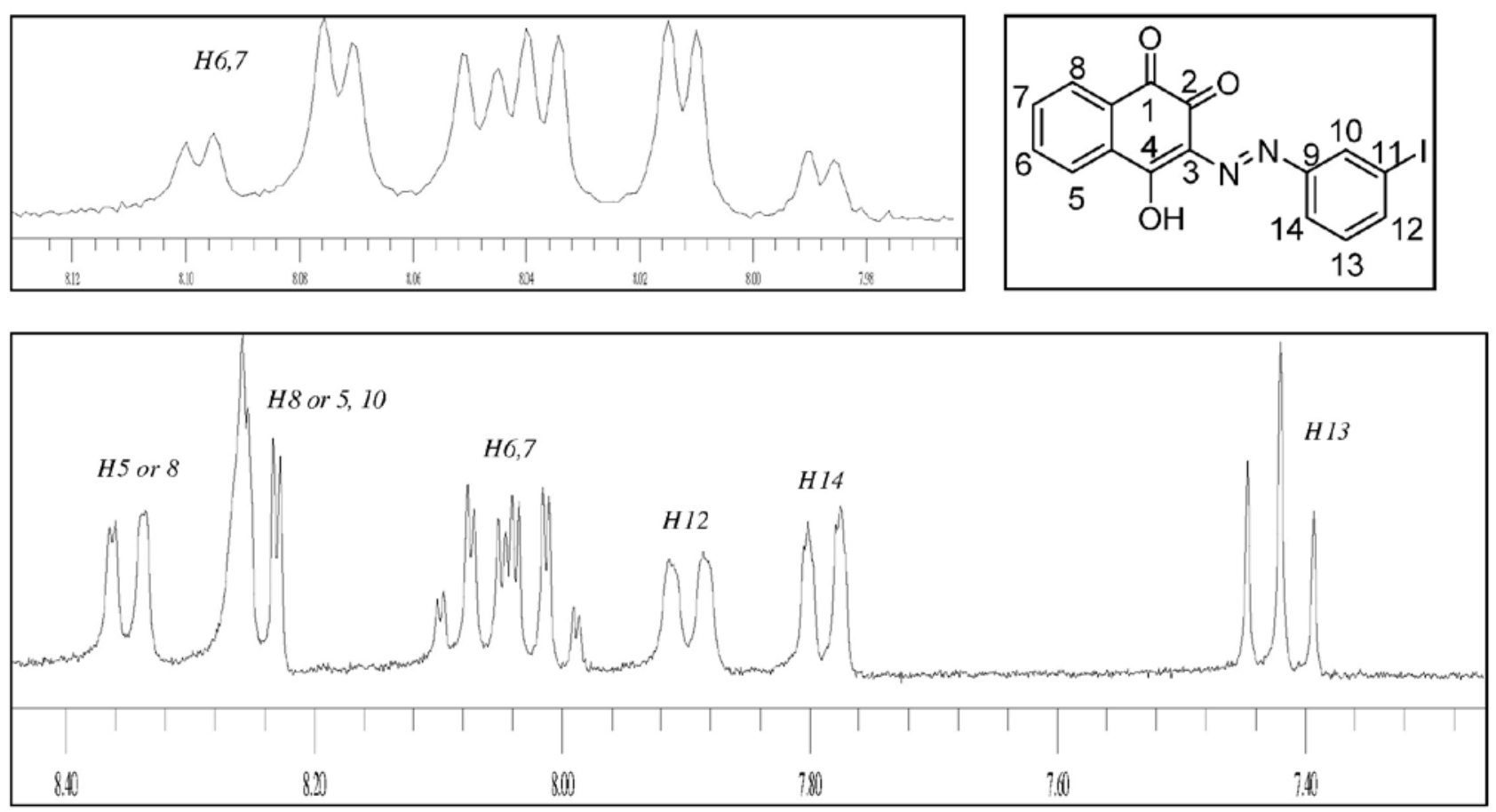

Figure S7. ${ }^{1} \mathrm{H}$ NMR spectrum of 3-[2-(3-iodo)phenylhydrazono]-naphthalene-1,2,4-trione (HL5). 


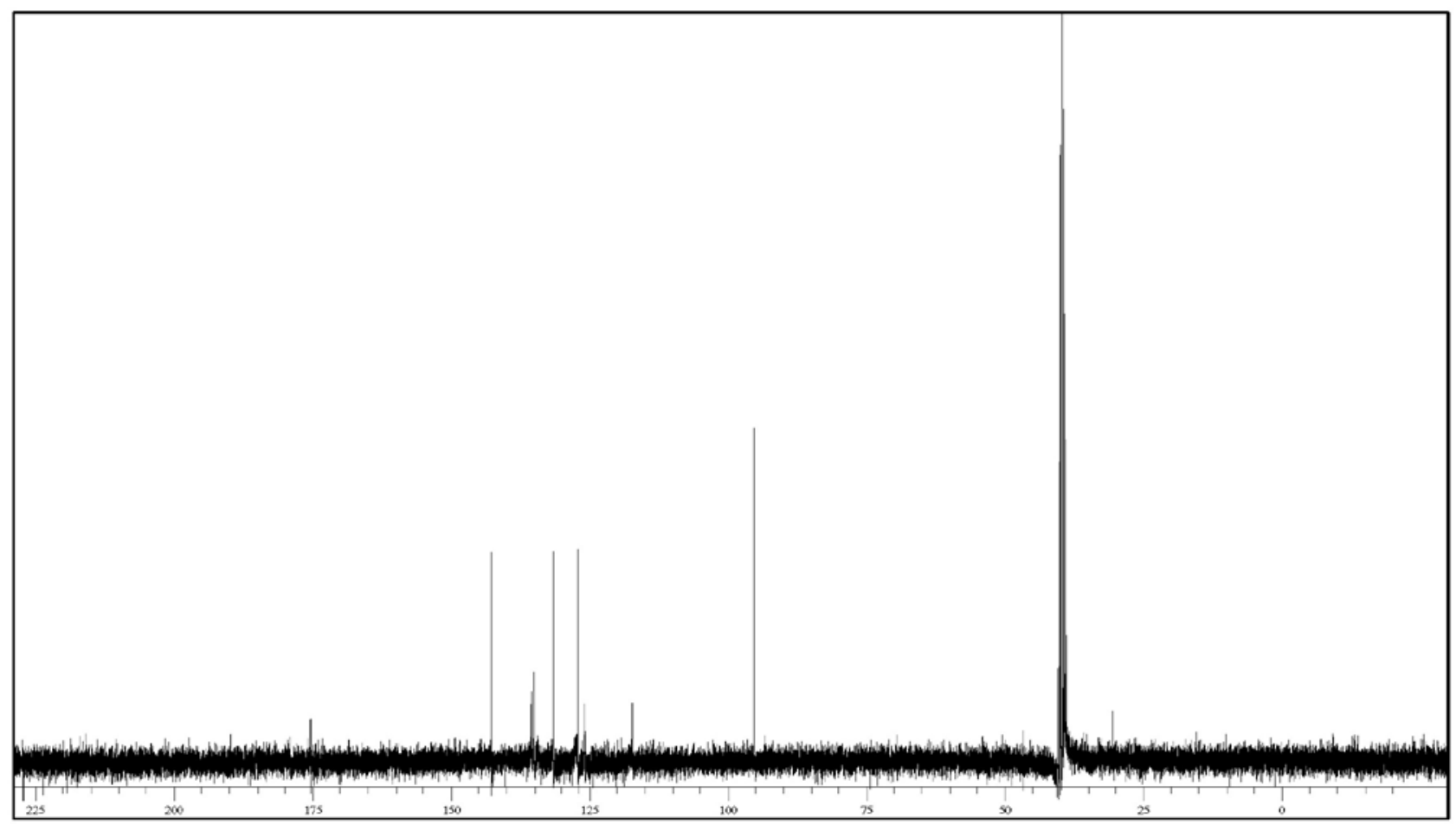

Figure S8. ${ }^{13}$ C NMR spectrum of 3-[2-(3-iodo)phenylhydrazono]-naphthalene-1,2,4-trione (HL5).
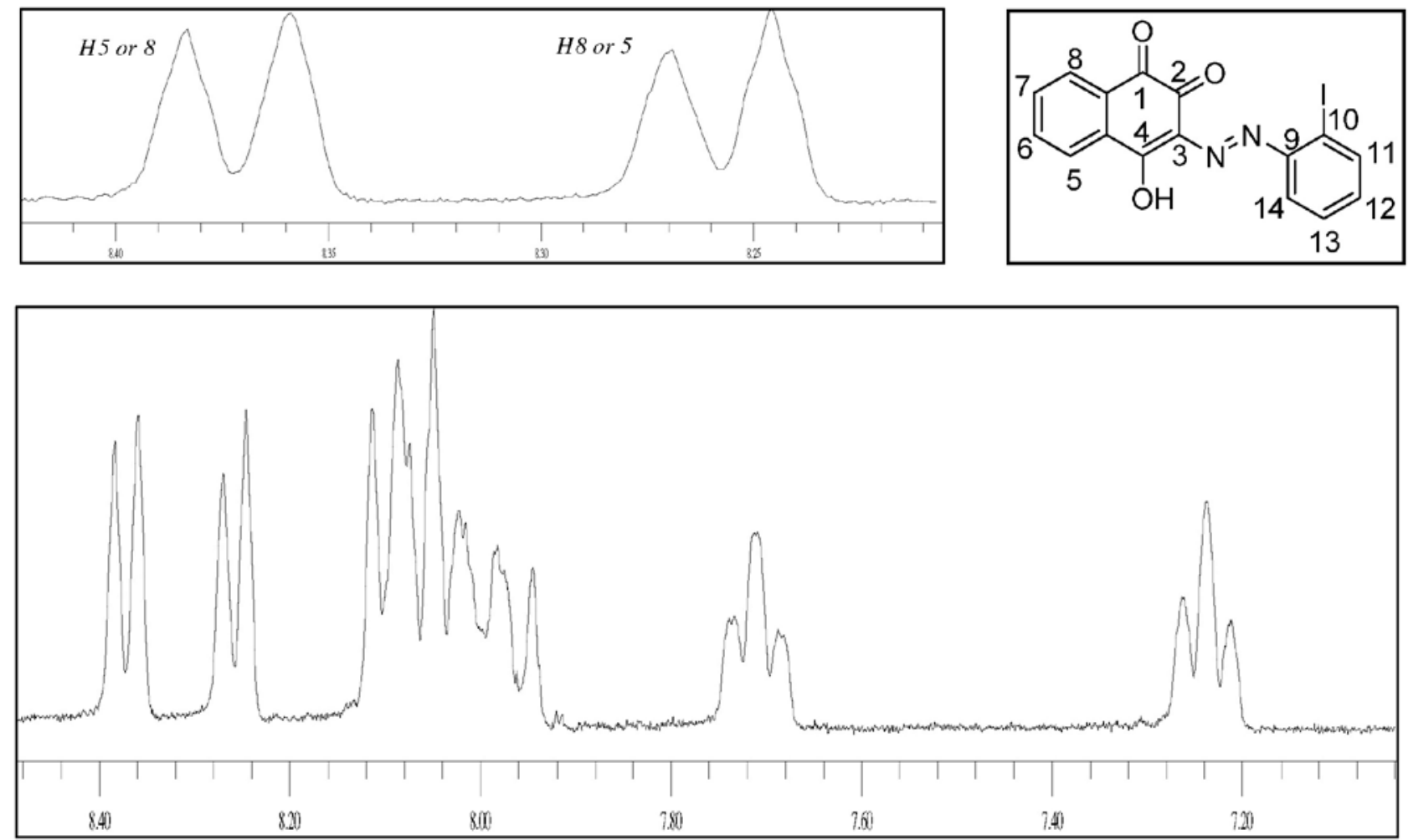

Figure S9. ${ }^{1} \mathrm{H}$ NMR spectrum of 3-[2-(2-iodo)phenylhydrazono]-naphthalene-1,2,4-trione (HL6). 


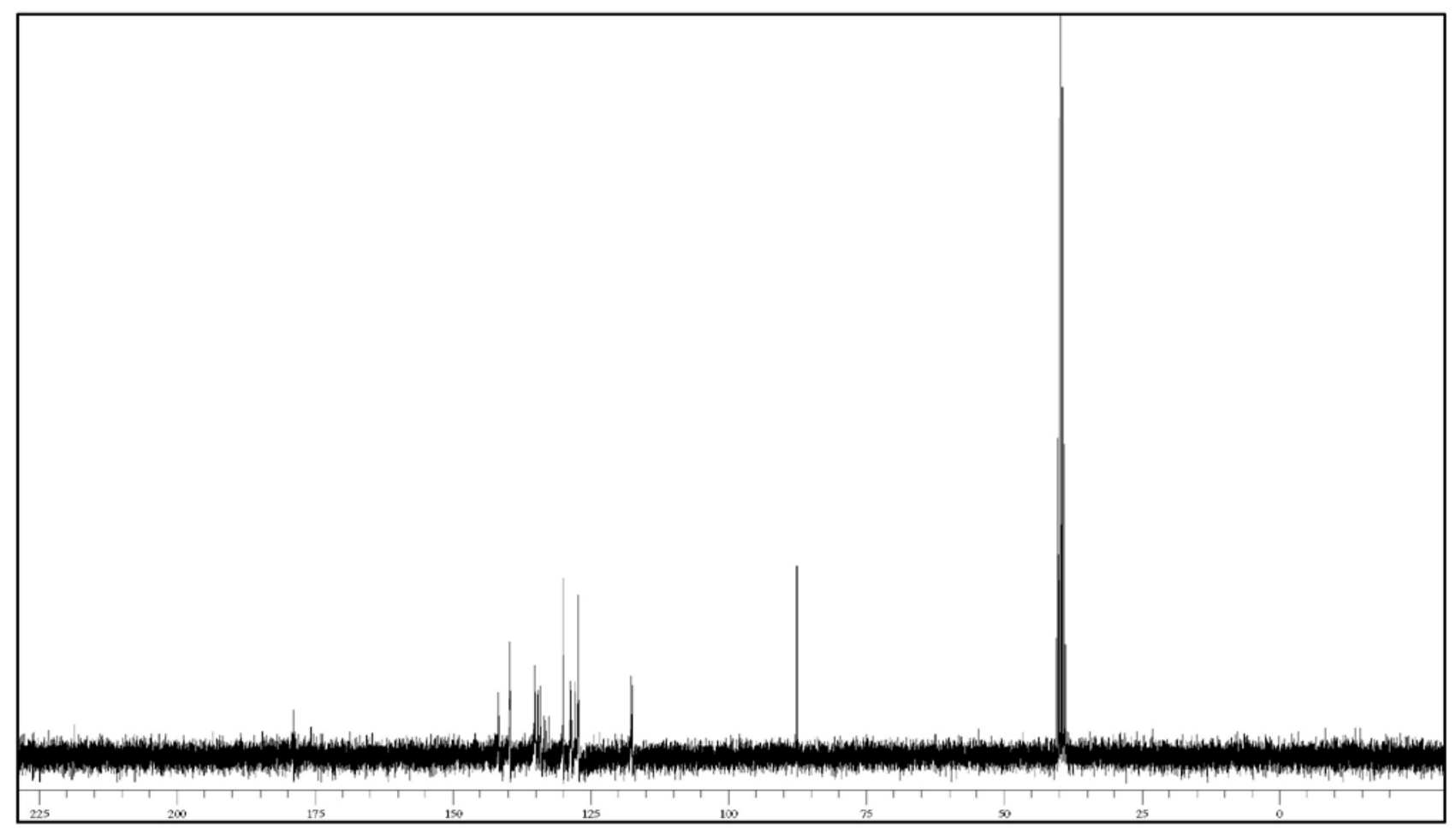

Figure S10. ${ }^{13} \mathrm{C}$ NMR spectrum of 3-[2-(2-iodo)phenylhydrazono]-naphthalene-1,2,4-trione (HL6).
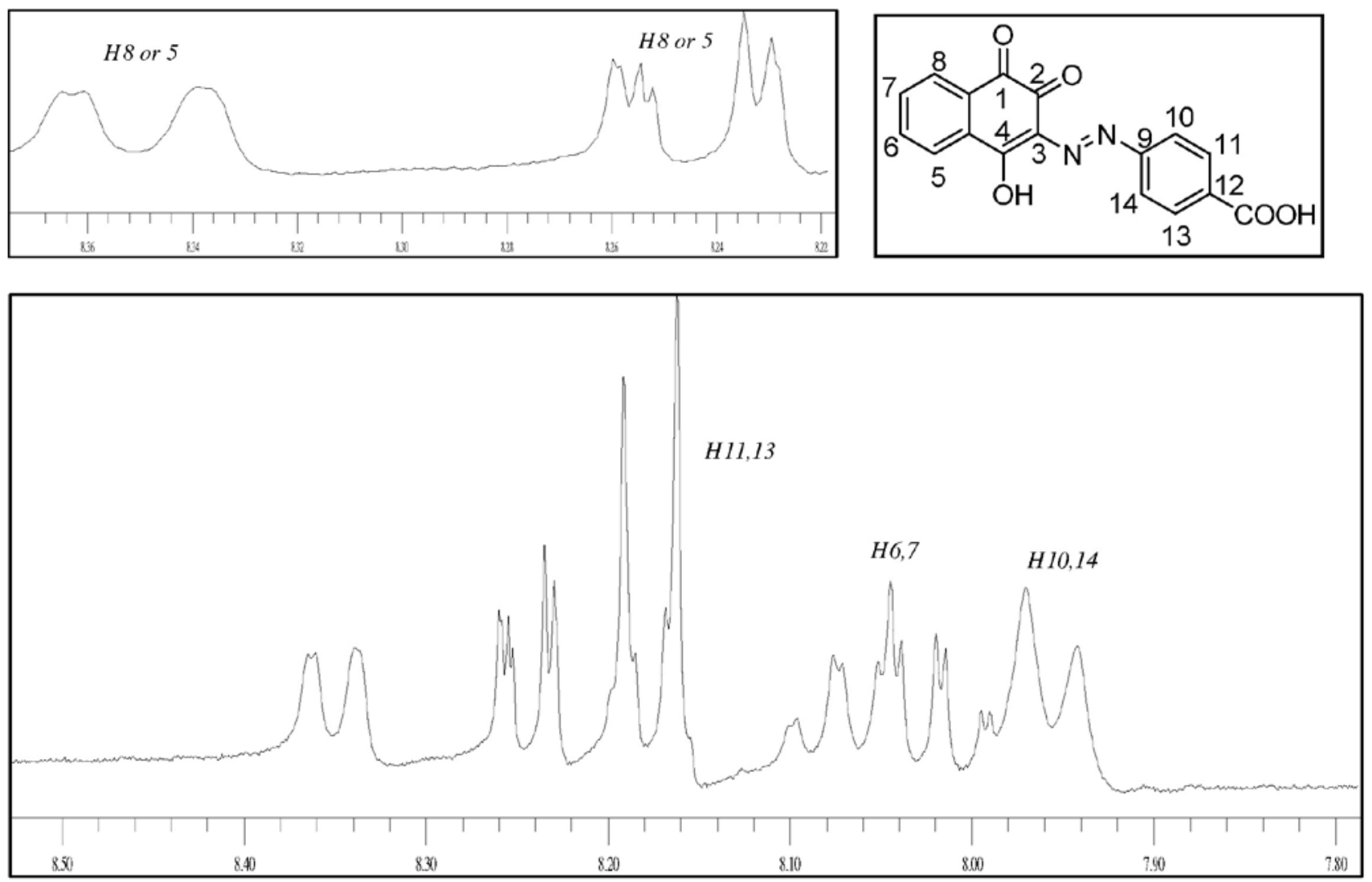

Figure S11. ${ }^{1} \mathrm{H}$ NMR spectrum of 3-[2-(4-carboxy)phenylhydrazono]-naphthalene-1,2,4-trione (HL7). 


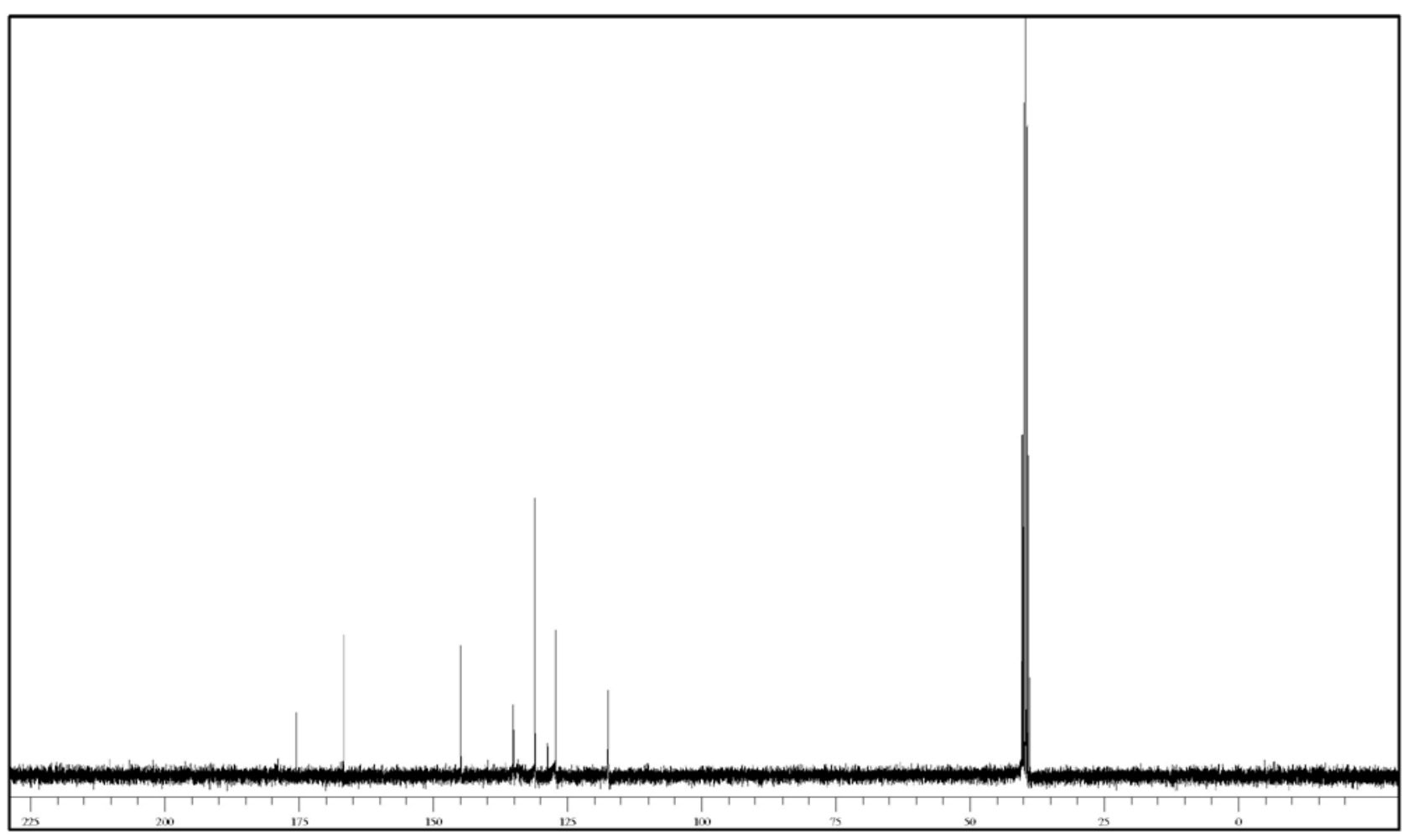

Figure S12. ${ }^{13}$ C NMR spectrum of 3-[2-(4-carboxy)phenylhydrazono]-naphthalene-1,2,4-trione (HL7).
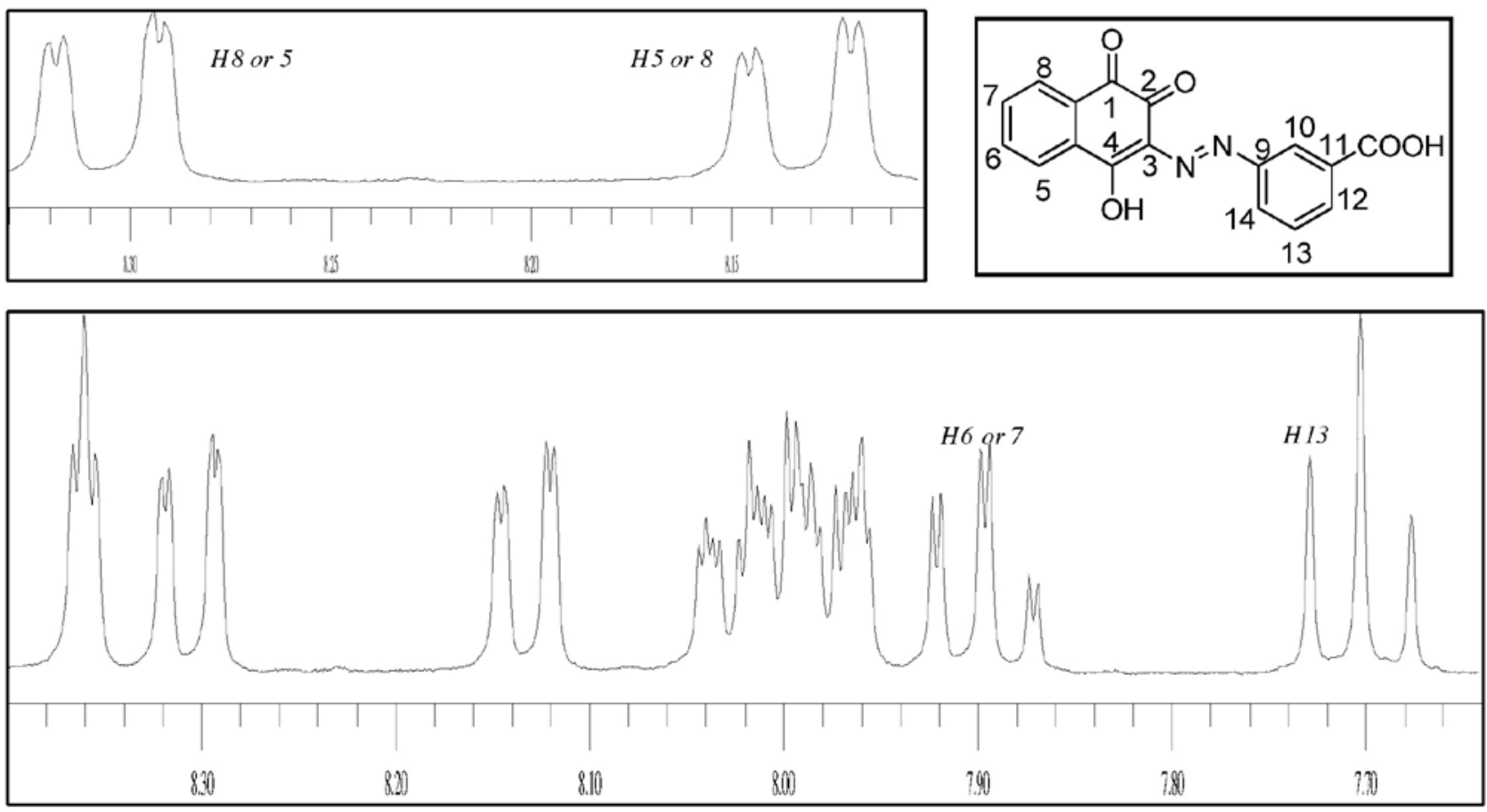

Figure S13. 'H NMR spectrum of 3-[2-(3-carboxy)phenylhydrazono]-naphthalene-1,2,4-trione (HL8). 


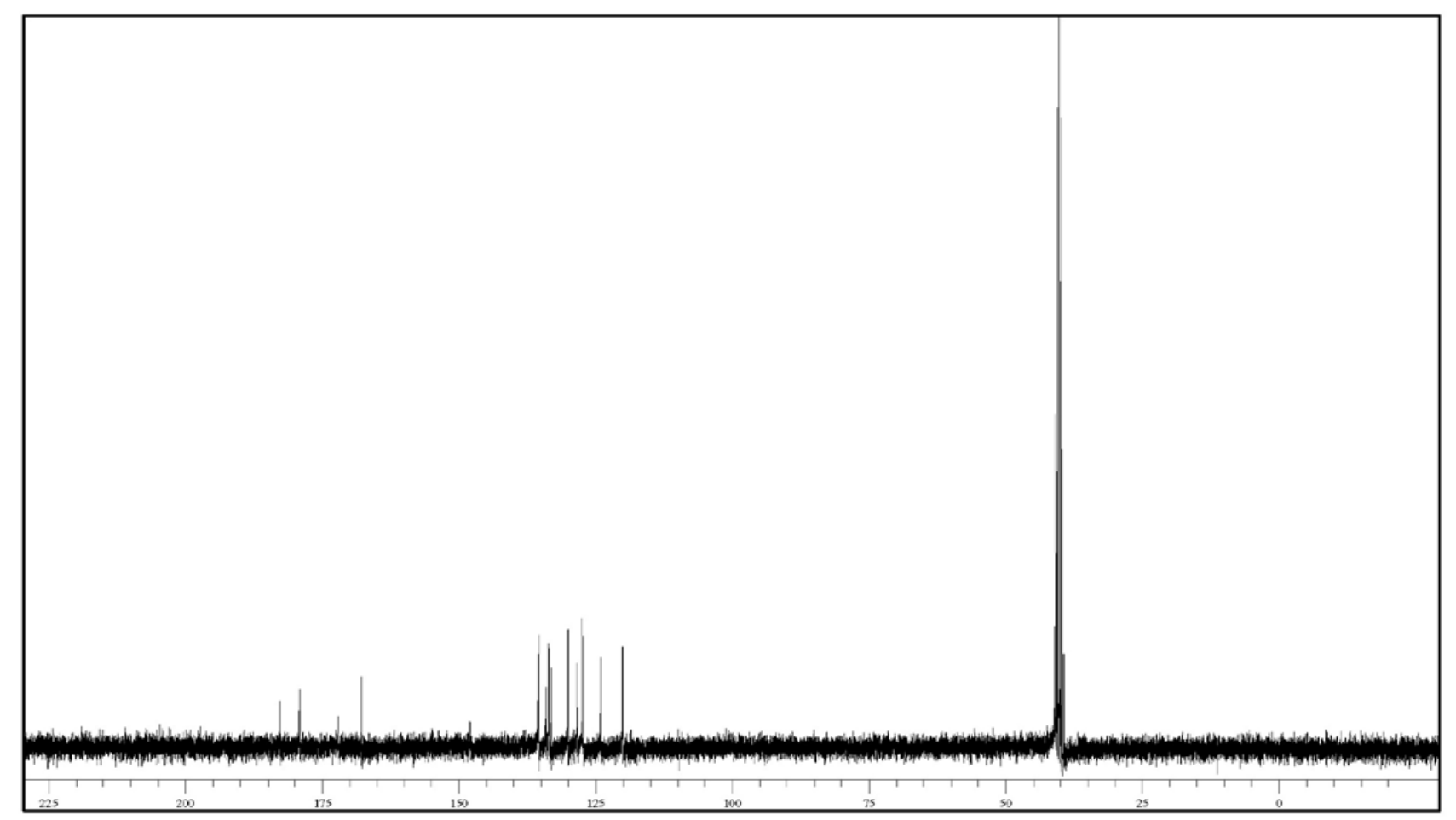

Figure S14. ${ }^{13} \mathrm{C}$ NMR spectrum of 3-[2-(3-carboxy)phenylhydrazono]-naphthalene-1,2,4-trione (HL8).
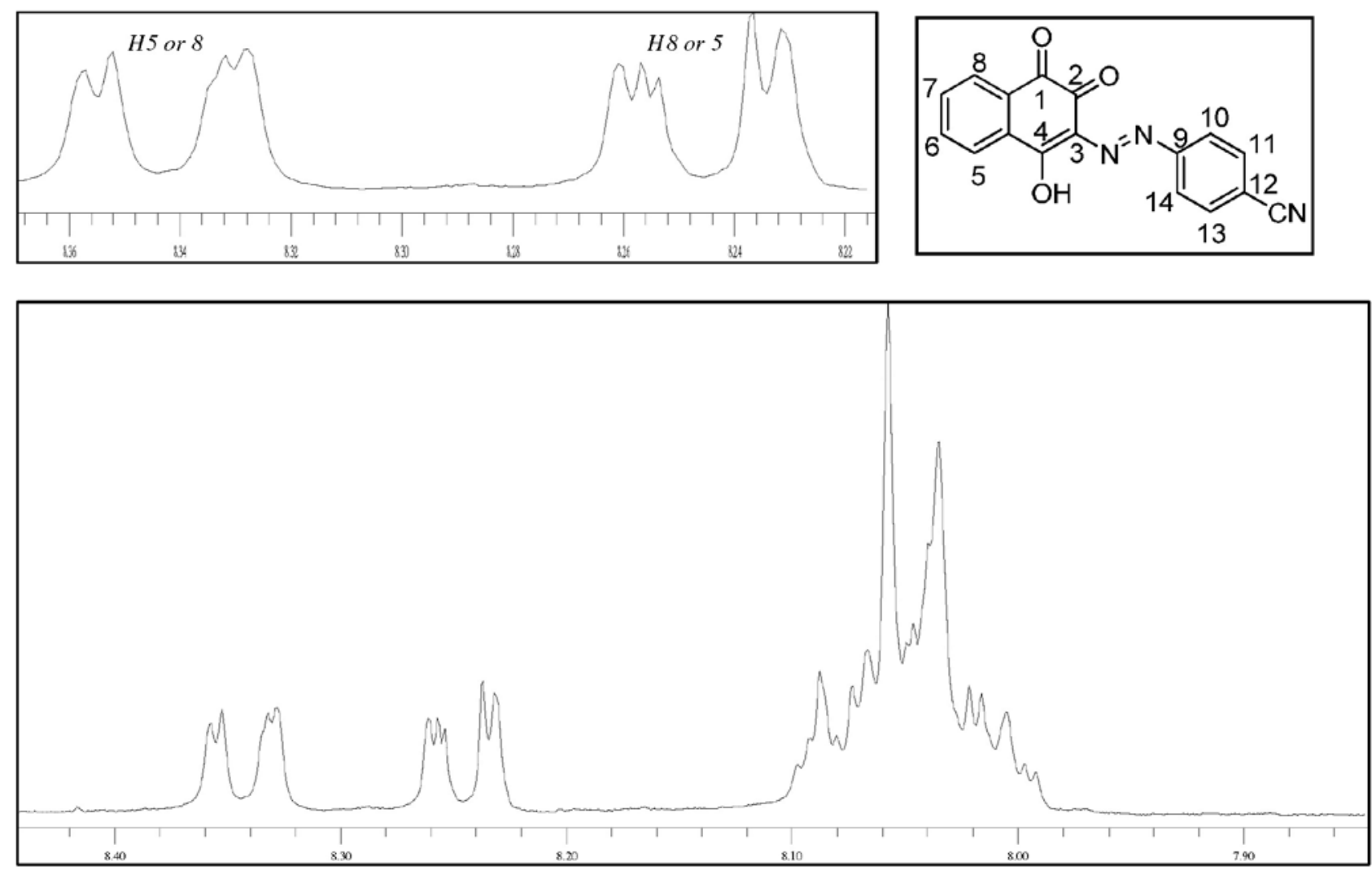

Figure S15. ${ }^{1} \mathrm{H}$ NMR spectrum of 3-[2-(4-ciano)phenylhydrazono]-naphthalene-1,2,4-trione (HL9). 


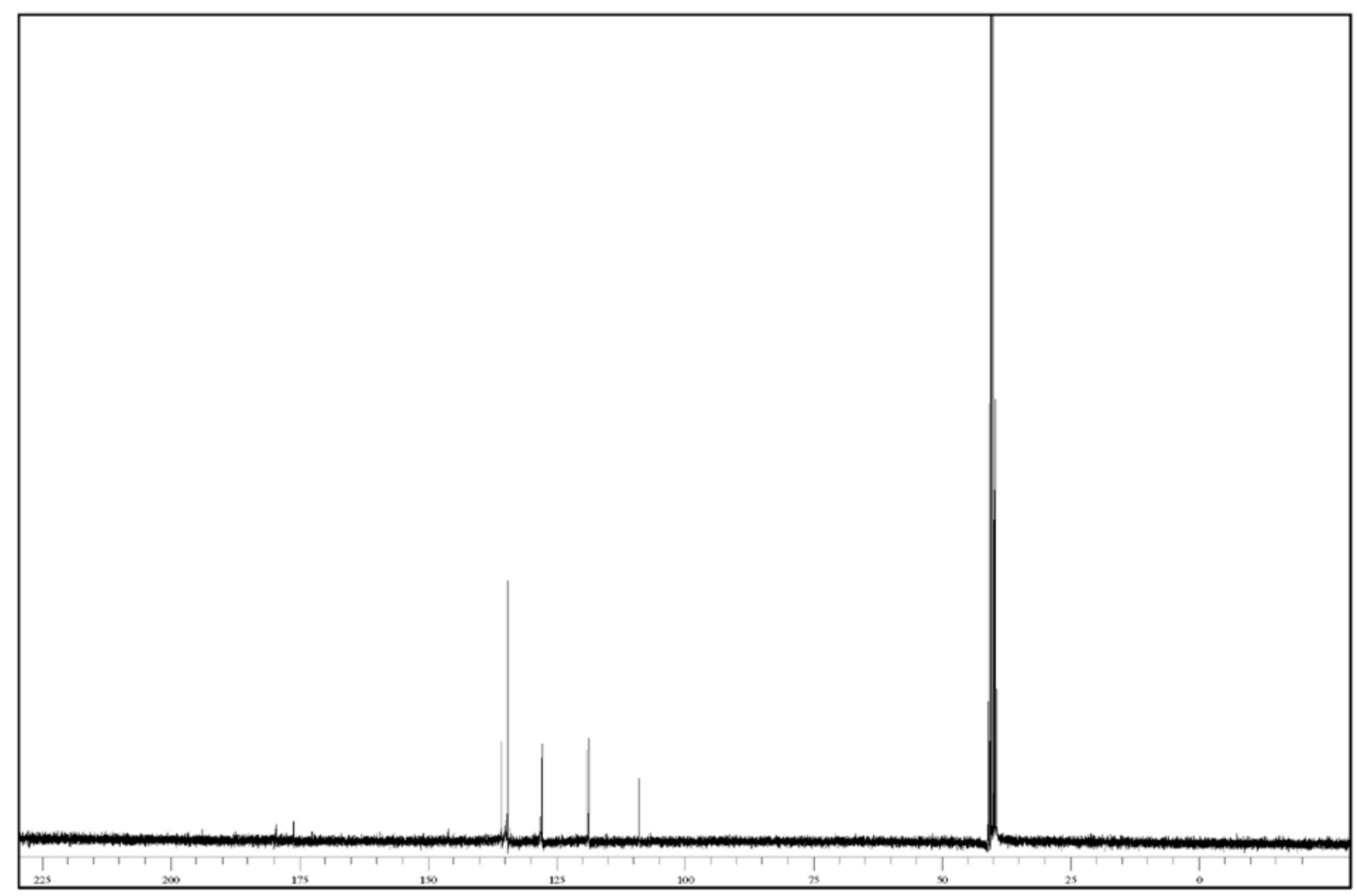

Figure S16. ${ }^{13} \mathrm{C}$ NMR spectrum of 3-[2-(4-ciano)phenylhydrazono]-naphthalene-1,2,4-trione (HL9).
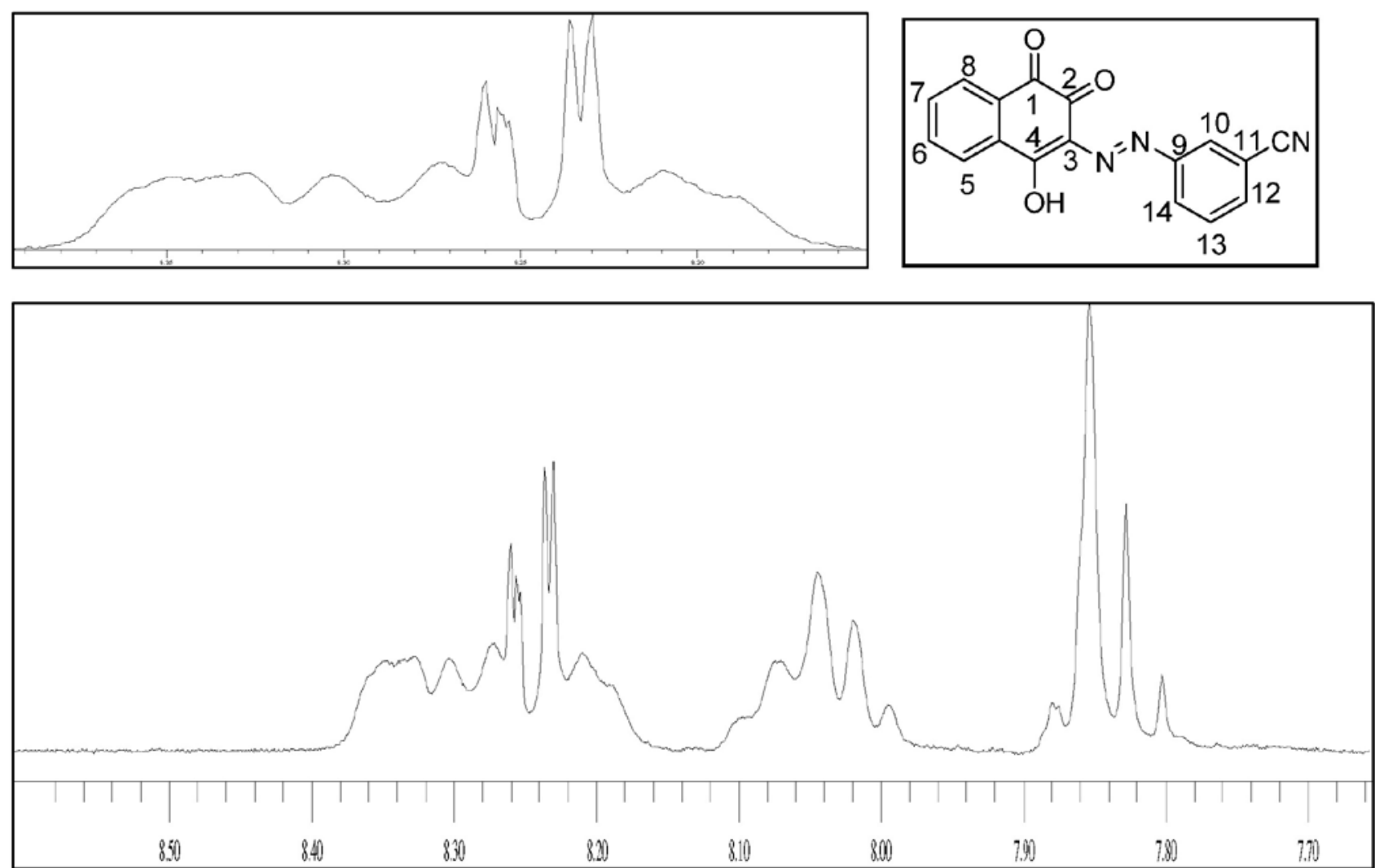

Figure S17. ${ }^{1} \mathrm{H}$ NMR spectrum of 3-[2-(3-ciano)phenylhydrazono]-naphthalene-1,2,4-trione (HL10). 


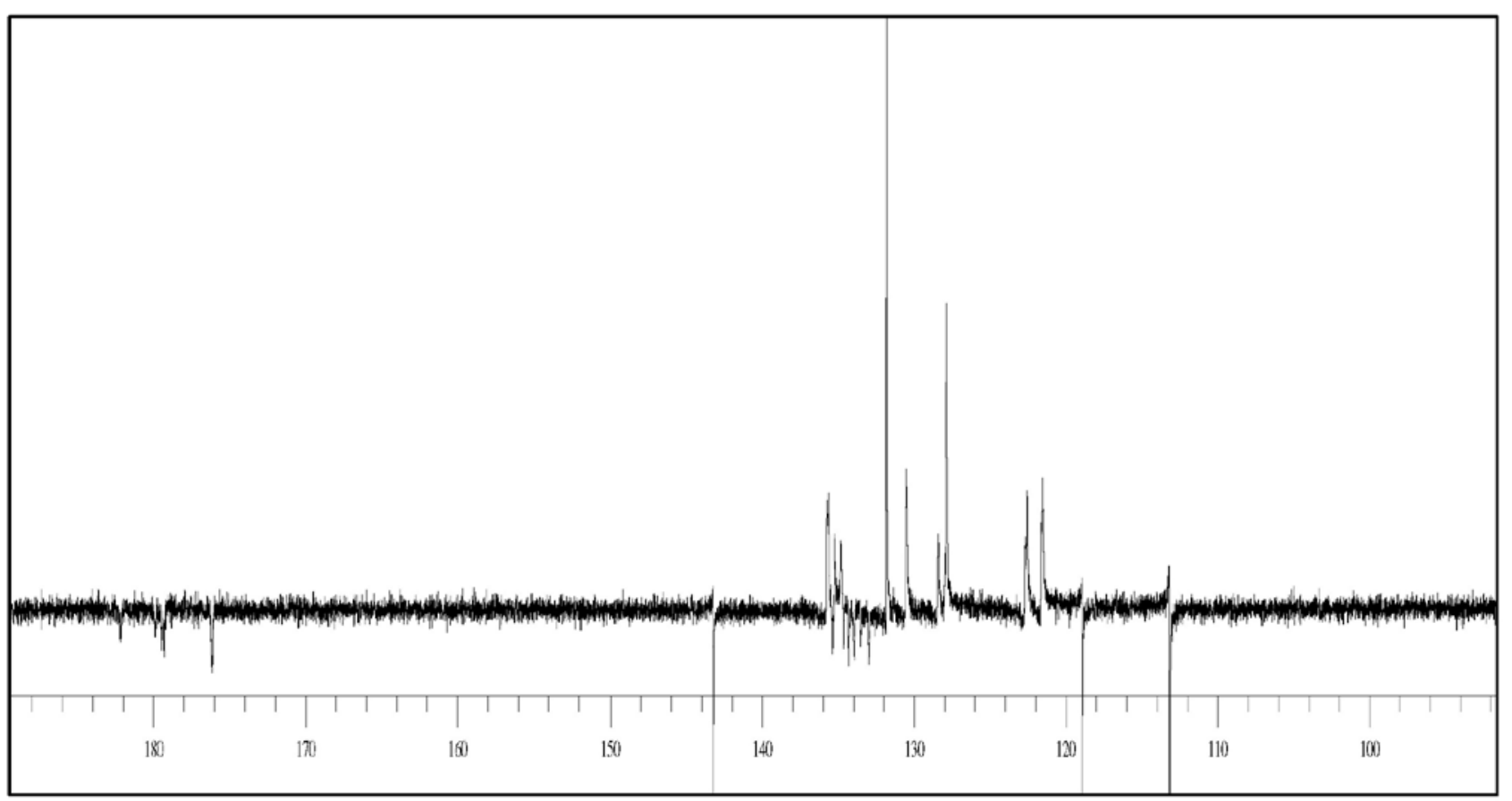

Figure S18. ${ }^{13} \mathrm{C}$ NMR spectrum of 3-[2-(3-ciano)phenylhydrazono]-naphthalene-1,2,4-trione (HL10).
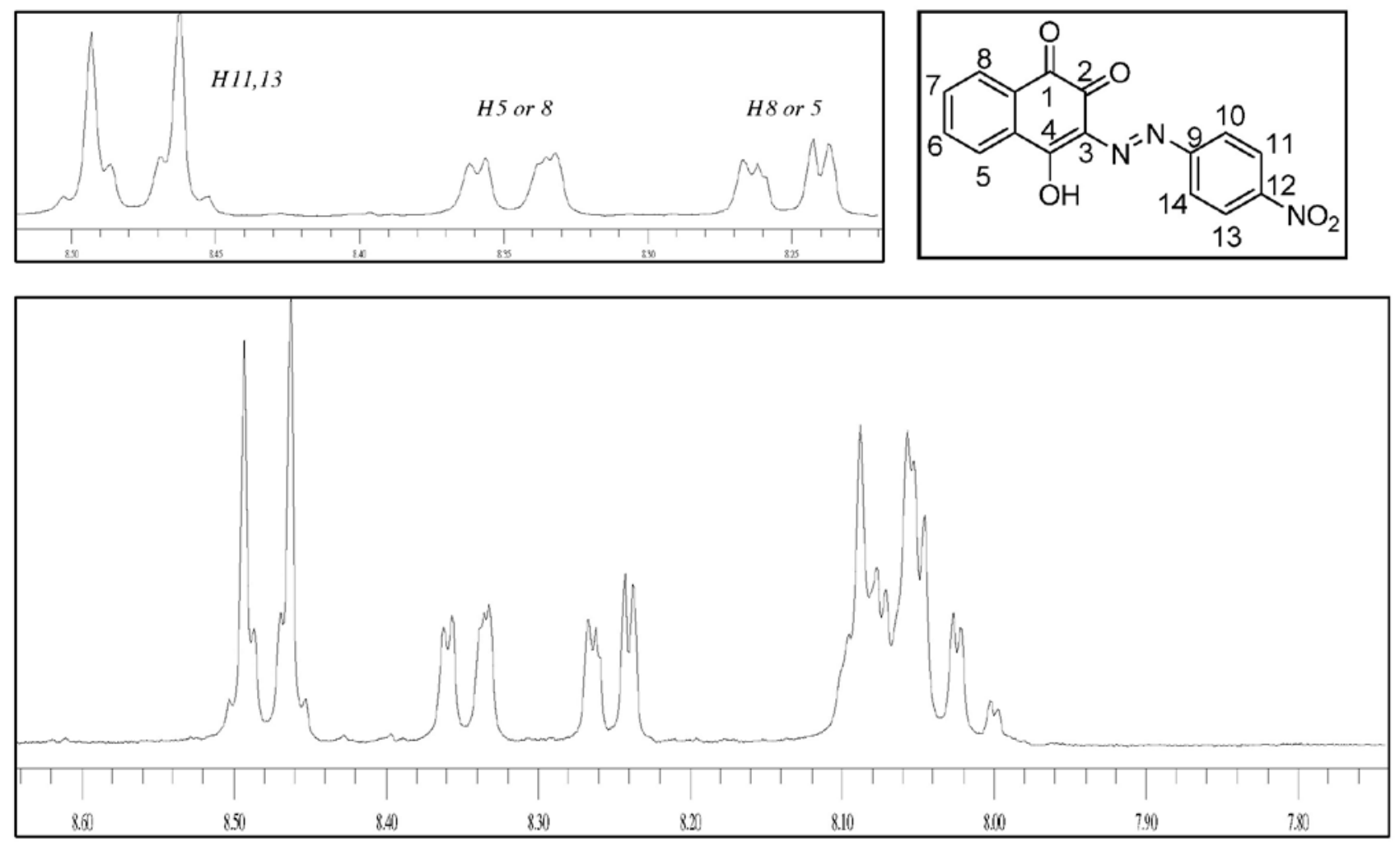

Figure S19. ${ }^{1} \mathrm{H}$ NMR spectrum of 3-[2-(4-nitro)phenylhydrazono]-naphthalene-1,2,4-trione (HL11) . 


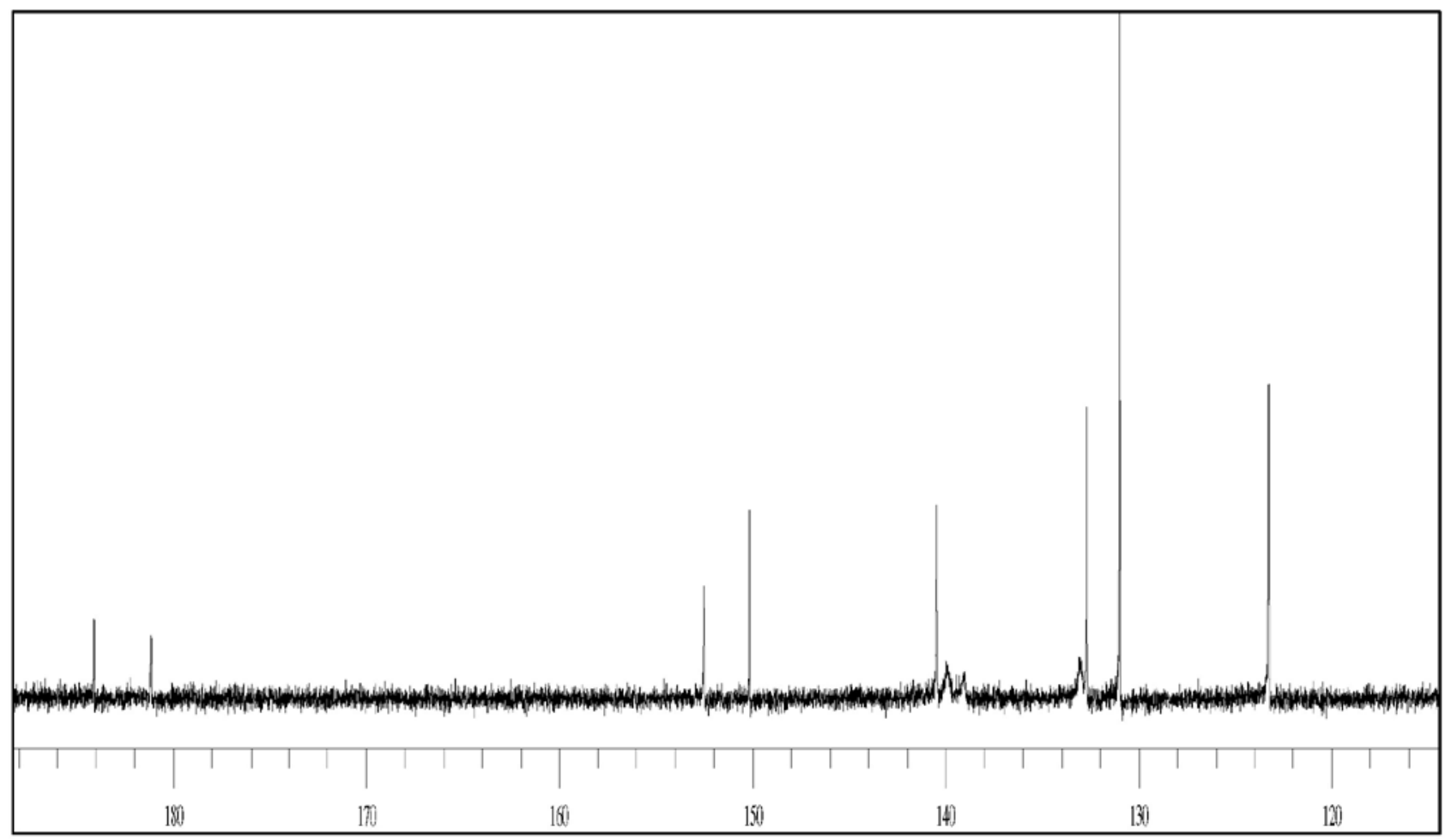

Figure S20. ${ }^{13} \mathrm{C}$ NMR spectrum of 3-[2-(4-nitro)phenylhydrazono]-naphthalene-1,2,4-trione (HL11).
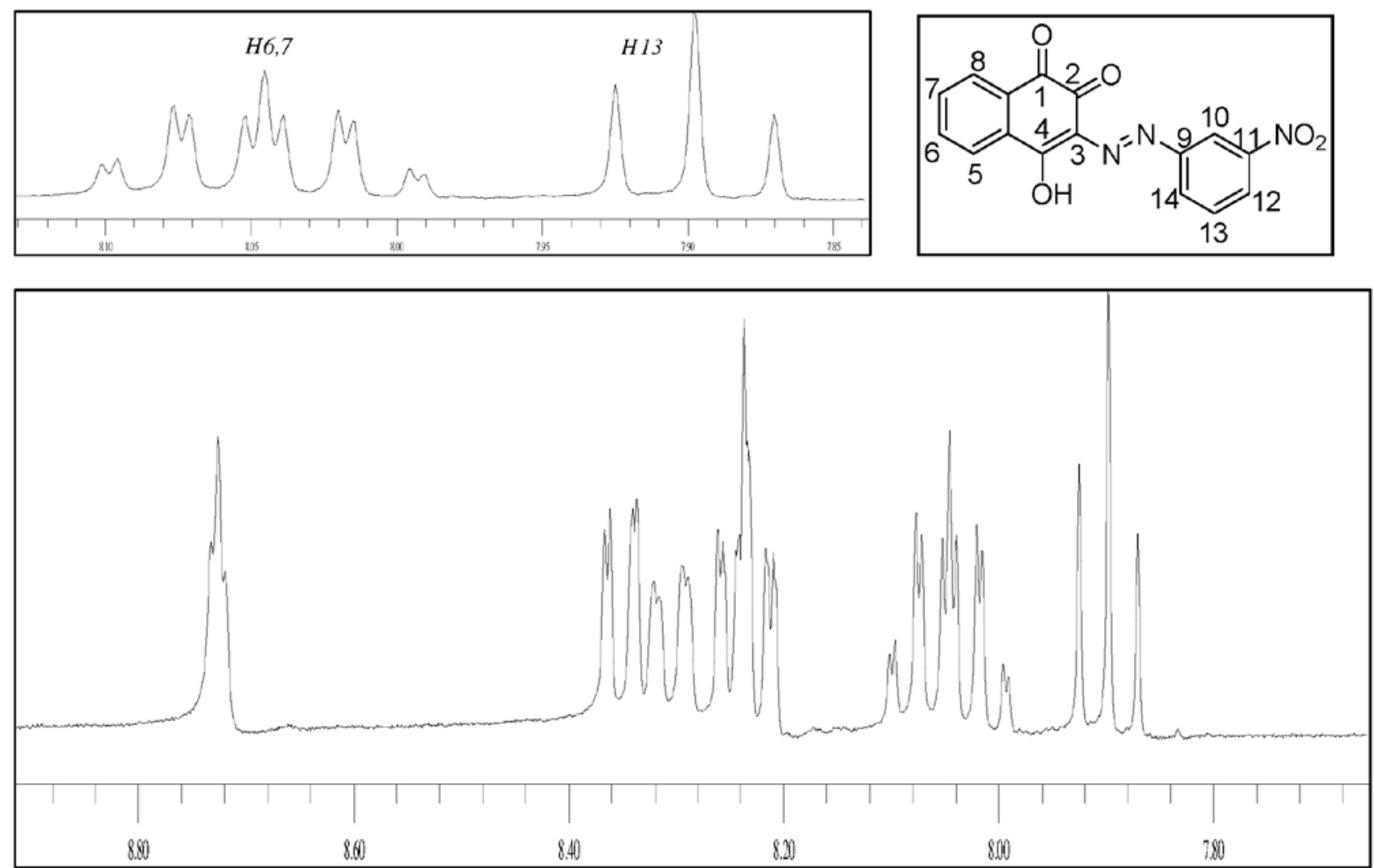

Figure S21. 'H NMR spectrum of 3-[2-(3-nitro)phenylhydrazono]-naphthalene-1,2,4-trione (HL12). 


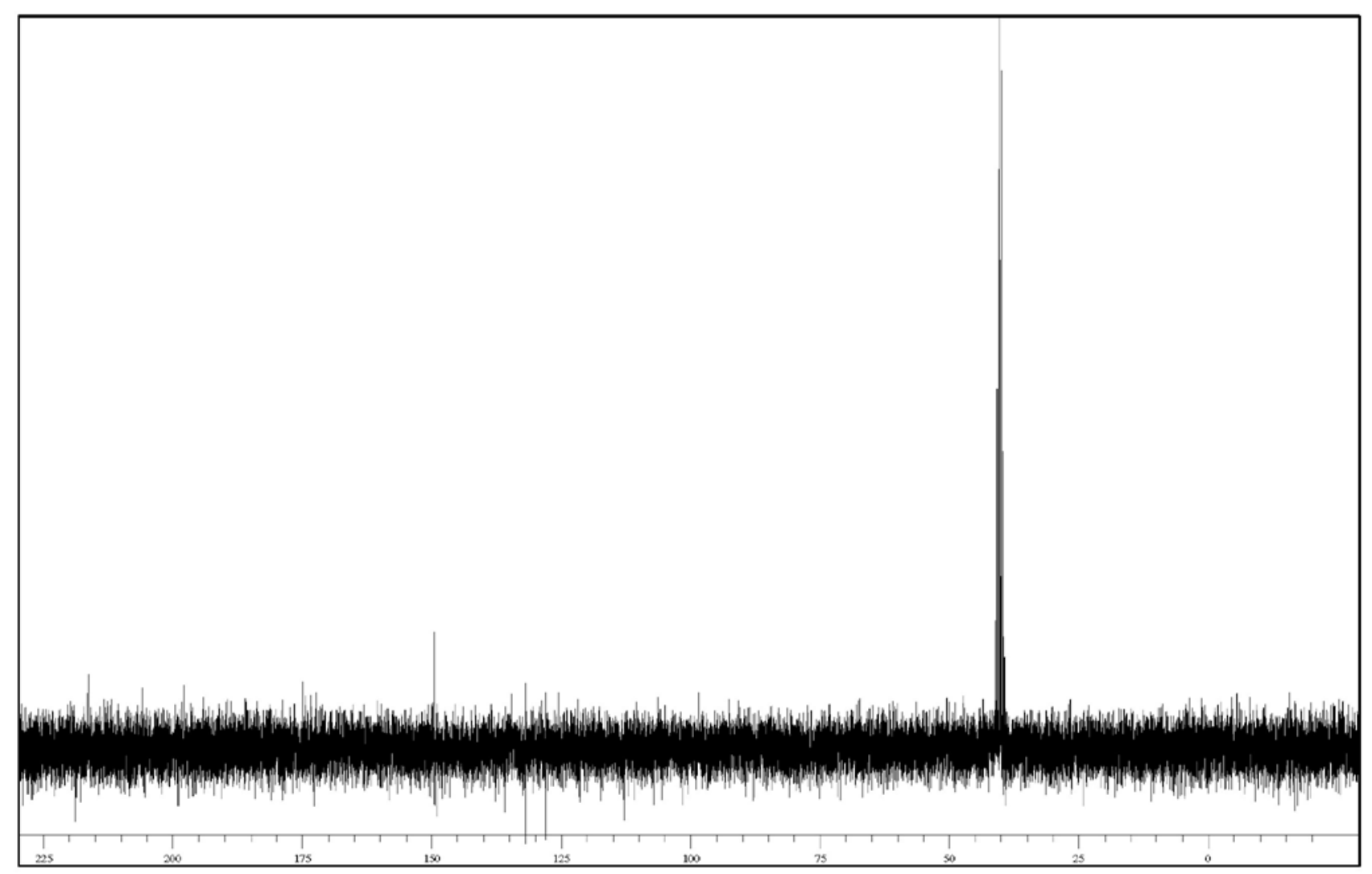

Figure S22. ${ }^{13} \mathrm{C}$ NMR spectrum of 3-[2-(3-nitro)phenylhydrazono]-naphthalene-1,2,4-trione (HL12).
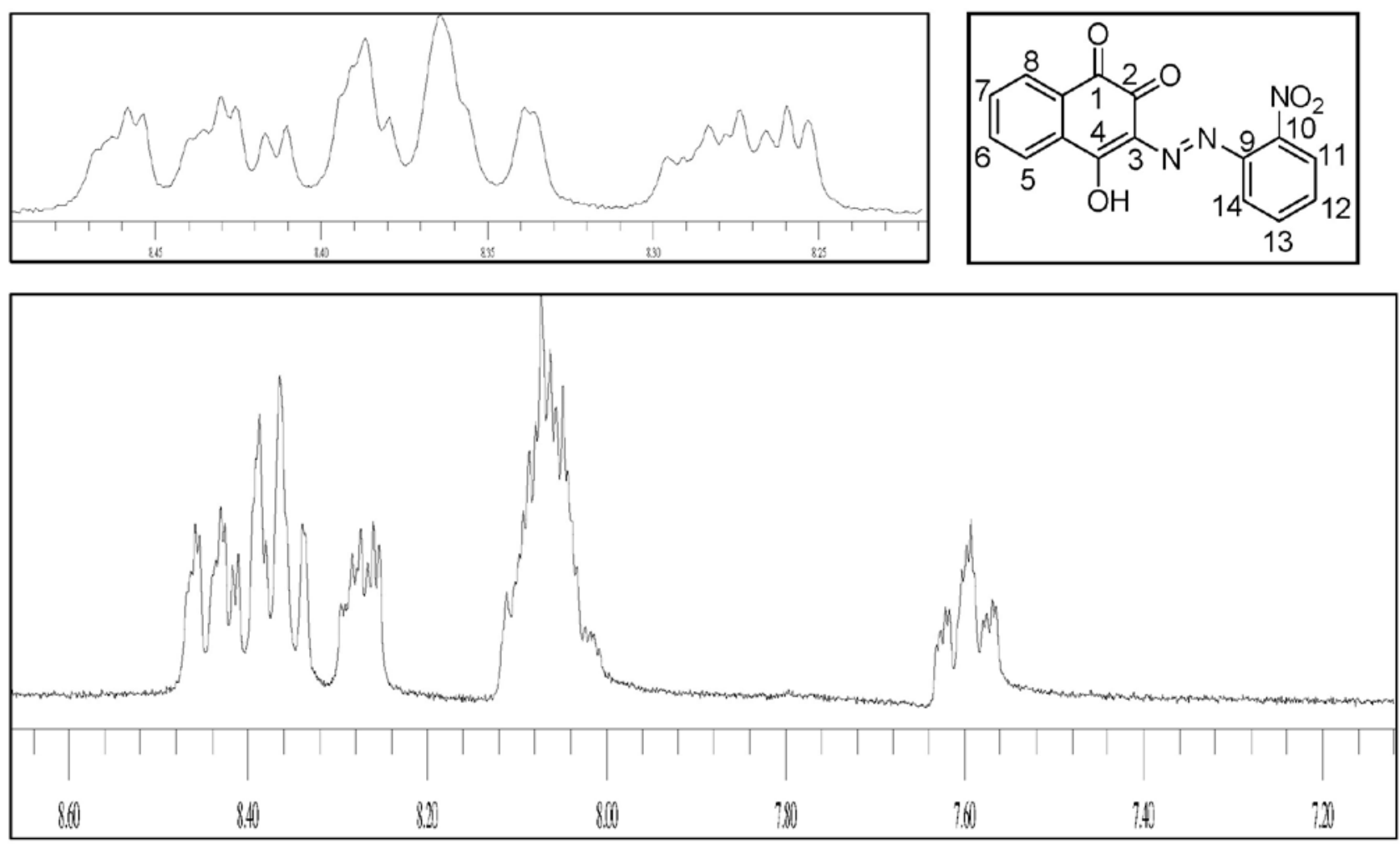

Figure S23. ${ }^{1} \mathrm{H}$ NMR spectrum of 3-[2-(2-nitro)phenylhydrazono]-naphthalene-1,2,4-trione (HL13). 


\section{Theoretical calculations}

\section{Relative energies of tautomers}

The table below presents absolute (hartree) and relative energies $\left(\mathrm{kcal} \mathrm{mol}^{-1}\right)$ of tautomers Ia, Ib, IIa and III with different substituents. In the first entry B3LYP/6-31G(d) results are given. The second entry refers to PBE1PBE/6$311+\mathrm{G}(2 \mathrm{~d}, \mathrm{p})$ results, including solvent effect (dmso).

Table S1. Absolute and relative energies $\left(\mathrm{kcal} \mathrm{mol}^{-1}\right)$ of tautomers Ia, Ib, IIa and IIb with different substituents

\begin{tabular}{|c|c|c|c|c|}
\hline $\mathrm{R}$ & Ia & Ib & IIa & III \\
\hline$\overline{\mathrm{H}}$ & $\begin{array}{c}-950.86824 \\
0.49 \\
-950.07927 \\
0.23\end{array}$ & $\begin{array}{c}-950.86902 \\
0.0 \\
-950.07963 \\
0.0\end{array}$ & $\begin{array}{c}-950.84219 \\
16.84 \\
-950.05670 \\
14.39\end{array}$ & $\begin{array}{c}-950.85681 \\
7.66 \\
-950.06850 \\
6.98\end{array}$ \\
\hline $\mathrm{CN}$ & $\begin{array}{c}-1043.11014 \\
0.34 \\
-1042.24636 \\
-0.01\end{array}$ & $\begin{array}{c}-1043.11068 \\
0.0 \\
-1042.24634 \\
0.0\end{array}$ & $\begin{array}{c}-1043.08445 \\
16.46 \\
-1042.22382 \\
14.13\end{array}$ & $\begin{array}{c}-1043.09815 \\
7.86 \\
-1042.23440 \\
7.49\end{array}$ \\
\hline $\mathrm{NO}_{2}$ & $\begin{array}{c}-1155.36828 \\
0.29 \\
-1154.44761 \\
-0.03\end{array}$ & $\begin{array}{c}-1155.36875 \\
0.0 \\
-1154.44757 \\
0.0\end{array}$ & $\begin{array}{c}-1155.34229 \\
16.60 \\
-1154.42494 \\
14.20\end{array}$ & $\begin{array}{c}-1155.35575 \\
8.16 \\
-1154.43524 \\
7.74\end{array}$ \\
\hline $\mathrm{NH}_{2}$ & $\begin{array}{c}-1006.22180 \\
0.67 \\
-1005.40727 \\
0.58\end{array}$ & $\begin{array}{c}-1006.22287 \\
0.0 \\
-1005.40819 \\
0.0\end{array}$ & $\begin{array}{c}-1006.19911 \\
14.91 \\
-1005.38686 \\
13.38\end{array}$ & \\
\hline $\mathrm{OCH}_{3}$ & $\begin{array}{c}-1065.39115 \\
0.63 \\
-1064.51448 \\
0.36\end{array}$ & $\begin{array}{c}-1065.39216 \\
0.0 \\
-1064.51505 \\
0.0\end{array}$ & $\begin{array}{c}-1065.36720 \\
15.66 \\
-1064.49338 \\
13.60\end{array}$ & $\begin{array}{c}-1065.38181 \\
6.49 \\
-1064.50567 \\
5.89\end{array}$ \\
\hline
\end{tabular}

\section{Electronic spectra of tautomers $\mathbf{I} \boldsymbol{a}$ and $\mathbf{I} \boldsymbol{b}$}

The electronic spectra of the hydrazono compounds were calculated with the RPBE/6-311+G(2d,p) method with inclusion of solvent effects using the CPCM approach and dmso as solvent. The geometries were optimized at the B3LYP/6-31G(d) level. These compounds may exist as a set of tautomers of which the two rotamers $\mathbf{I a}$ and $\mathbf{I b}$ are the most stable (Figure S24). For each tautomer two high intensity bands were calculated. In each case they correspond to transitions of the type HOMO $\rightarrow$ LUMO and HOMO $\rightarrow$ LUMO+1. HOMO is one of the $\pi$ orbitals of the phenyl ring (Figures S25 and S28) while LUMO and LUMO+1 both are $\pi^{*}$ orbitals of the quinone ring (Figures S26 and S29, respectively).

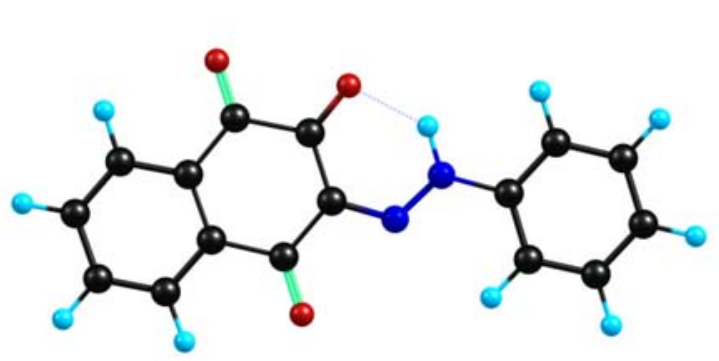

Ia

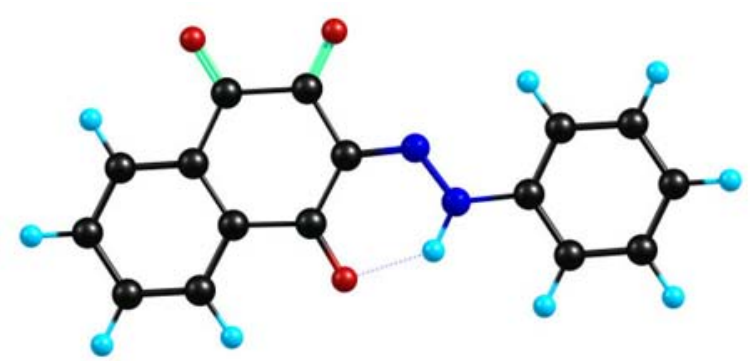

Ib

Figure S24. Hydrazono compounds Ia and Ib. 
Table S2. Theoretical electronic spectra of tautomers $\mathbf{I a}$ and $\mathbf{I} \mathbf{b}^{(*)}$

\begin{tabular}{|c|c|c|}
\hline & Ib & Ia \\
\hline & \multicolumn{2}{|c|}{$\mathrm{R}=\mathrm{H}$} \\
\hline$\lambda 1(\mathrm{HOMO} \rightarrow \mathrm{LUMO})$ & $449(0.13)$ & $457(0.34)$ \\
\hline \multirow[t]{2}{*}{$\lambda 2(\mathrm{HOMO} \rightarrow \mathrm{LUMO}+1)$} & $407(0.81)$ & $387(0.60)$ \\
\hline & \multicolumn{2}{|c|}{$\mathrm{R}=\mathrm{CN}$} \\
\hline$\lambda 1(\mathrm{HOMO} \rightarrow \mathrm{LUMO})$ & $426(0.42)$ & $438(0.58)$ \\
\hline \multirow{2}{*}{$\lambda 2(\mathrm{HOMO} \rightarrow \mathrm{LUMO}+1)$} & $399(0.75)$ & $375(0.59)$ \\
\hline & \multicolumn{2}{|c|}{$\mathrm{R}=\mathrm{NO}_{2}$} \\
\hline$\lambda 1(\mathrm{HOMO} \rightarrow \mathrm{LUMO})$ & $424(0.87)$ & $435(0.77)$ \\
\hline \multirow[t]{2}{*}{$\lambda 2(\mathrm{HOMO} \rightarrow \mathrm{LUMO}+1)$} & $398(0.39)$ & $377(0.47)$ \\
\hline & \multicolumn{2}{|c|}{$\mathrm{R}=\mathrm{NH}_{2}$} \\
\hline$\lambda 1(\mathrm{HOMO} \rightarrow \mathrm{LUMO})$ & $598(0.11)$ & $598(0.30)$ \\
\hline \multirow[t]{2}{*}{$\lambda 2(\mathrm{HOMO} \rightarrow \mathrm{LUMO}+1)$} & $505(0.91)$ & $483(0.72)$ \\
\hline & \multicolumn{2}{|c|}{$\mathrm{R}=\mathrm{OCH}_{3}$} \\
\hline$\lambda 1(\mathrm{HOMO} \rightarrow \mathrm{LUMO})$ & & $508(0.37)$ \\
\hline$\lambda 2(\mathrm{HOMO} \rightarrow \mathrm{LUMO}+1)$ & & $423(0.64)$ \\
\hline
\end{tabular}

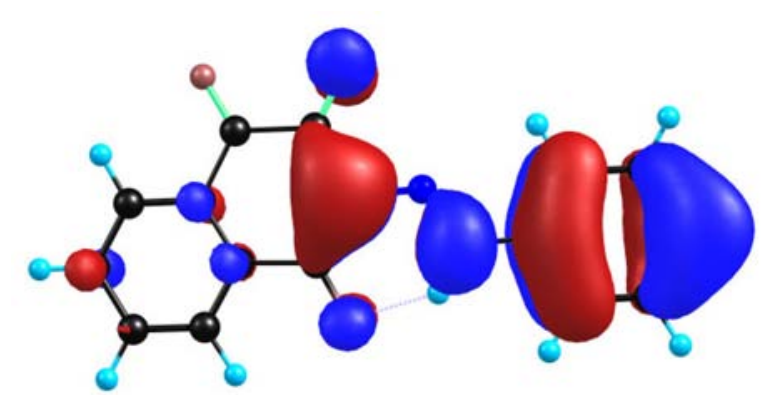

Figure S25. HOMO of rotamer Ib $(\mathrm{R}=\mathrm{H})$.

(*) $\lambda$ is given in $\mathrm{nm}$. The oscillator strength is given in parenthesis. Spectra are calculated at the RPBE/6-311+G(2d,p) level with inclusion of solvent effects (dmso).

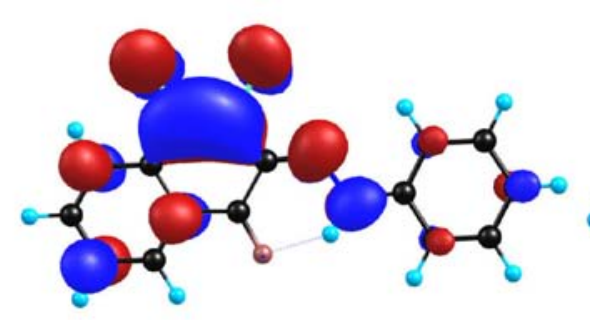

a) LUMO

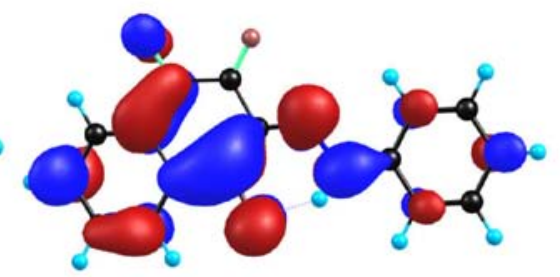

b) $\mathrm{LUMO}+1$

Figure S26. a) LUMO and b) LUMO+1 of rotamer $\mathbf{I b}(\mathrm{R}=\mathrm{H})$.

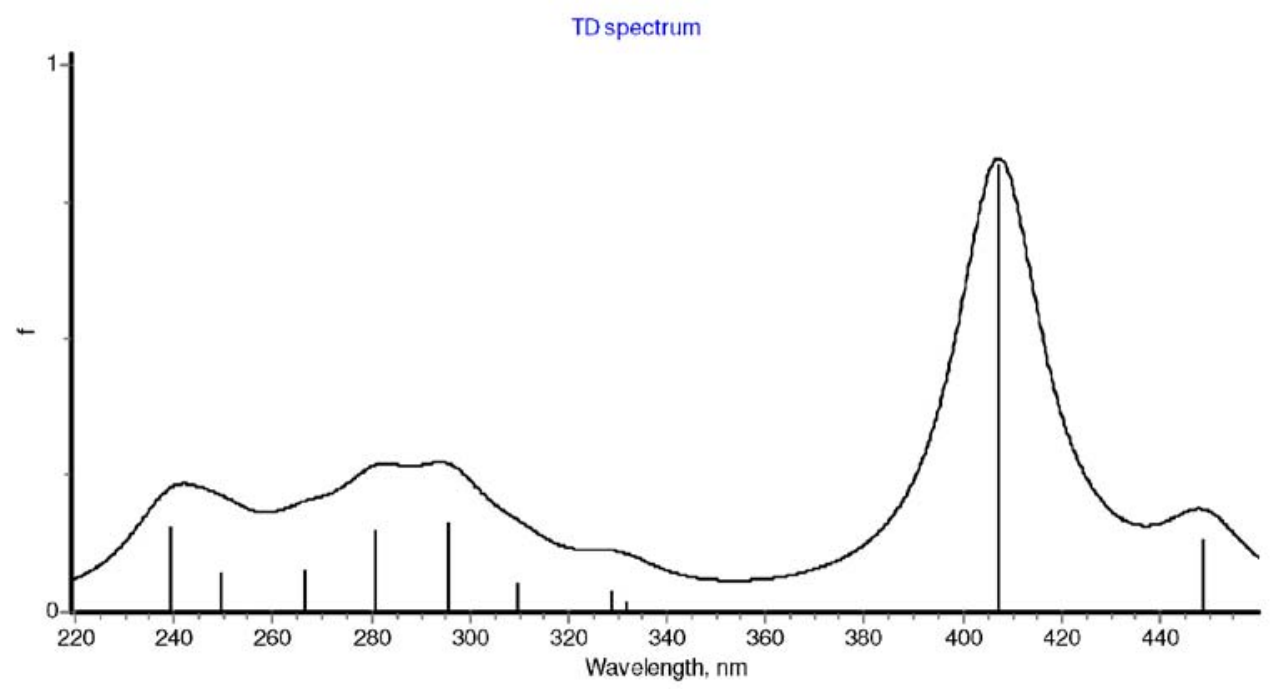

Figure S27. TDDFT spectrum of rotamer $\mathbf{I b}(\mathrm{R}=\mathrm{H})$. 


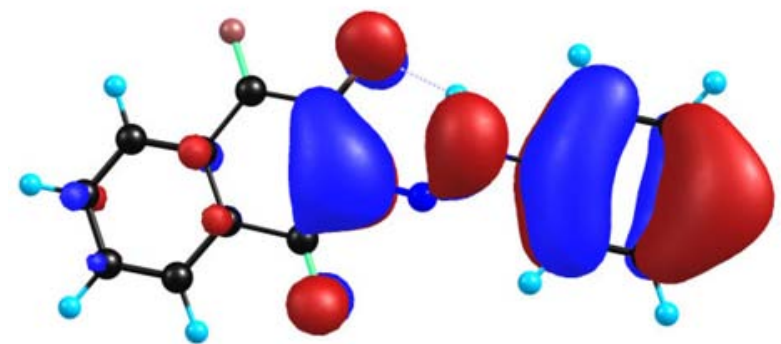

Figure S28. HOMO of rotamer Ia $(\mathrm{R}=\mathrm{H})$.

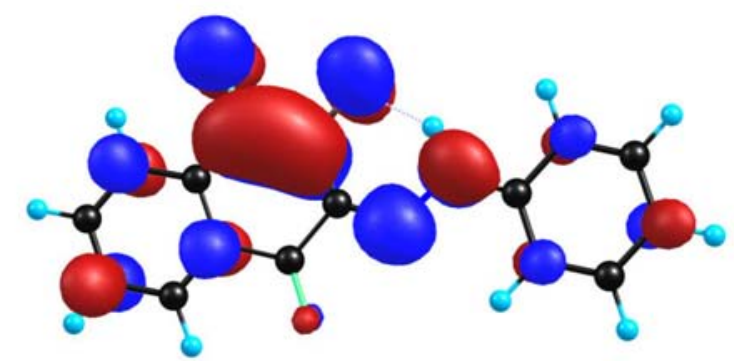

a) LUMO

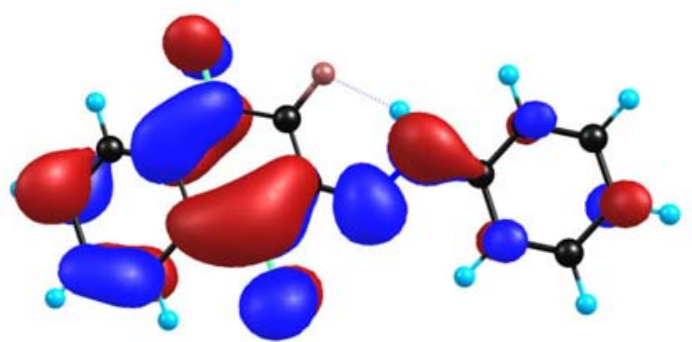

b) $\mathrm{LUMO}+1$

Figure S29. a) LUMO and b) LUMO+1 of rotamer $\mathbf{I a}(\mathrm{R}=\mathrm{H})$.

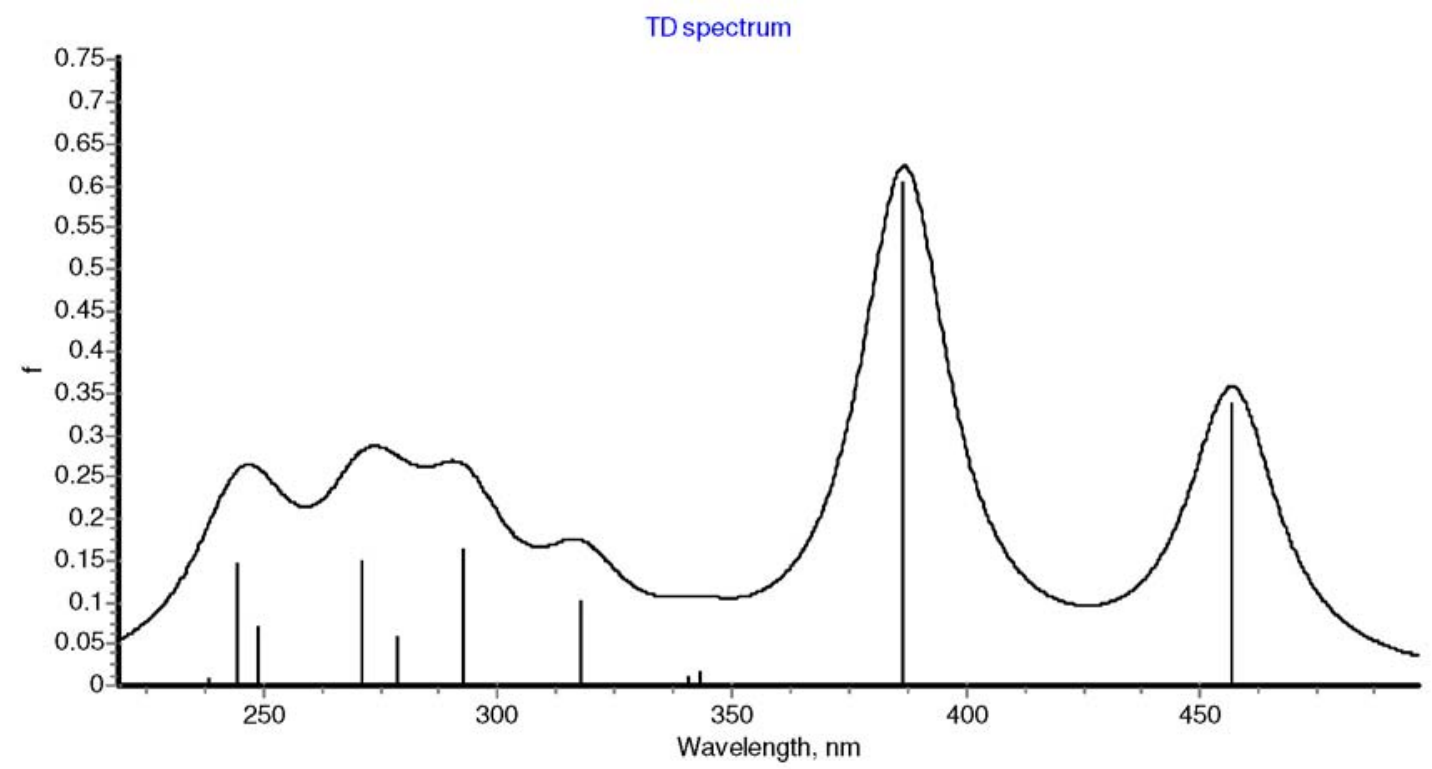

Figure S30. TDDFT spectrum of rotamer Ia $(\mathrm{R}=\mathrm{H})$. 


\section{Theoretical ${ }^{13} \mathrm{C}$ and ${ }^{1} \mathrm{H}$ chemical shifts (ppm)}

Table S3. B3LYP/6-31G(d,p) relative ${ }^{13} \mathrm{C}$ and ${ }^{1} \mathrm{H}$ chemical shifts (ppm) for the unsubstituted derivatives Ia, Ib, IIb, and III. Me ${ }_{4} \mathrm{Si}$ (tms) was used as reference. Absolute ${ }^{13} \mathrm{C}$ and ${ }^{1} \mathrm{H}$ chemical shifts of tms are 191.61 and $31.71 \mathrm{ppm}$, respectively

\begin{tabular}{|c|c|c|c|c|}
\hline Atom & Ia & Ib & IIb & III \\
\hline $\mathrm{C} 1$ & 175.72 & 173.33 & 172.68 & 177.99 \\
\hline $\mathrm{C} 2$ & 170.76 & 168.59 & 167.83 & 148.26 \\
\hline $\mathrm{C} 3$ & 130.42 & 129.69 & 129.12 & 129.11 \\
\hline $\mathrm{C} 4$ & 172.53 & 176.96 & 160.21 & 174.61 \\
\hline $\mathrm{C} 4 \mathrm{a}$ & 130.72 & 130.41 & 127.36 & 127.72 \\
\hline C5 & 124.72 & 124.48 & 123.58 & 123.89 \\
\hline C6 & 129.16 & 128.57 & 128.50 & 129.07 \\
\hline $\mathrm{C} 7$ & 127.16 & 128.12 & 127.55 & 126.96 \\
\hline $\mathrm{C} 8$ & 124.85 & 125.92 & 126.28 & 122.96 \\
\hline $\mathrm{C} 8 \mathrm{a}$ & 128.66 & 129.26 & 128.41 & 127.44 \\
\hline C9 & 136.45 & 136.45 & 144.91 & 145.91 \\
\hline $\mathrm{C} 10$ & 113.69 & 111.77 & 111.91 & 125.54 \\
\hline C11 & 123.80 & 125.40 & 124.44 & 123.72 \\
\hline $\mathrm{C} 12$ & 122.15 & 121.88 & 125.59 & 126.64 \\
\hline $\mathrm{C} 13$ & 125.28 & 123.57 & 123.43 & 124.45 \\
\hline $\mathrm{C} 14$ & 111.88 & 111.35 & 123.85 & 111.79 \\
\hline H5 & 8.54 & 8.48 & 8.25 & 8.47 \\
\hline H6 & 7.79 & 7.76 & 7.67 & 7.78 \\
\hline $\mathrm{H} 7$ & 7.73 & 7.75 & 7.68 & 7.72 \\
\hline $\mathrm{H} 8$ & 8.42 & 8.44 & 8.37 & 8.31 \\
\hline $\mathrm{H} 10$ & 7.04 & 8.36 & 8.42 & 7.71 \\
\hline H11 & 7.43 & 7.56 & 7.54 & 7.58 \\
\hline H12 & 7.31 & 7.29 & 7.45 & 7.51 \\
\hline H13 & 7.56 & 7.43 & 7.54 & 7.55 \\
\hline H14 & 8.38 & 6.99 & 7.57 & 8.40 \\
\hline
\end{tabular}

Analytical and spectroscopic data for complexes 1-13

$\left[\mathrm{Cu}(\mathbf{L 1})_{2}\right](\mathbf{1})$

From $308 \mathrm{mg}$ of HL1. Yield: $481 \mathrm{mg}, 71 \%$; mp 297-300 ${ }^{\circ} \mathrm{C}$ with decomposition. Anal. calcd. for $\mathrm{C}_{34} \mathrm{H}_{22} \mathrm{CuN}_{4} \mathrm{O}_{8} \cdot 0.8 \mathrm{H}_{2} \mathrm{O}: \mathrm{C} 49.54 ; \mathrm{H} 4.89 ; \mathrm{N} 6.80 \%$. Found: C 49.52; H 4.79; N 6.74\%. IR ( KBr, $\left.v_{\max } / \mathrm{cm}^{-1}\right): 3445(\mathrm{O}-\mathrm{H})$, 3088 (C-H arom.), 1683 and $1658(\mathrm{C}=\mathrm{O}), 1600(\mathrm{C}=\mathrm{C})$, 1270 (C-O), 975 (C-N=N-C). UV-Vis [dmso; $\lambda / \mathrm{nm}$ (log ع)]: 279 (4.59), 459 (3.51). Diffuse reflectance $[\lambda / \mathrm{nm}]: 586$.

\section{$\left[\mathrm{Cu}(\mathrm{L2})_{2}\right](2)$}

From $382 \mathrm{mg}$ of HL2. Yield: $668 \mathrm{mg}, 81 \%$; mp $275-277{ }^{\circ} \mathrm{C}$ with decomposition. Anal. calcd. for $\mathrm{C}_{44} \mathrm{H}_{26} \mathrm{CuN}_{8} \mathrm{O}_{6} \cdot 0.2 \mathrm{H}_{2} \mathrm{O}: \mathrm{C} 61.14 ; \mathrm{H} 3.73 ; \mathrm{N} 12.96 \%$. Found: C 61.07; H 3.69; N 12.93\%. IR (KBr, $\left.v_{\max } / \mathrm{cm}^{-1}\right): 3447(\mathrm{O}-\mathrm{H})$, 3090 (C-H arom.), 1685 and $1663(\mathrm{C}=\mathrm{O}), 1595(\mathrm{C}=\mathrm{C})$,
1277 (C-O), 975 (C-N=N-C). UV-Vis [dmso; $\lambda / \mathrm{nm}$ (log $\varepsilon)]: 256$ (4.64), 457 (3.74), 581 (2.33).

$\left[\mathrm{Cu}(\mathbf{L} \mathbf{3})_{2}\right](\mathbf{3})$

From $312 \mathrm{mg}$ of HL3. Yield: $603 \mathrm{mg}, 88 \%$; mp 237-239 ${ }^{\circ} \mathrm{C}$ with decomposition. Anal. calcd. for $\mathrm{C}_{32} \mathrm{H}_{16} \mathrm{Cl}_{2} \mathrm{CuN}_{4} \mathrm{O}_{6} \cdot 0.5 \mathrm{H}_{2} \mathrm{O}: \mathrm{C} 49.34 ; \mathrm{H} 3.62 ; \mathrm{N} 7.19 \%$. Found: C 49.24; $\mathrm{H} 3.59$; N 7.09\%. IR $\left(\mathrm{KBr}, \mathrm{v}_{\max } / \mathrm{cm}^{-1}\right)$ : $3448(\mathrm{O}-\mathrm{H}), 3097$ (C-H arom.), $1675(\mathrm{C}=\mathrm{O}), 1585(\mathrm{C}=\mathrm{C})$, 1278 (C-O), $976(\mathrm{C}-\mathrm{N}=\mathrm{N}-\mathrm{C})$. UV-Vis [dmso; $\lambda / \mathrm{nm}(\log \varepsilon)$ ]: 277 (4.37), 431 (3.34). Diffuse reflectance $[\lambda / \mathrm{nm}]: 629$.

\section{$\left[\mathrm{Cu}(\mathrm{L4})_{2}\right](\mathbf{4})$}

From $404 \mathrm{mg}$ of HL4. Yield: $634 \mathrm{mg}, 73 \%$; mp 210-213 ${ }^{\circ} \mathrm{C}$ with decomposition. Anal. calcd. for $\mathrm{C}_{32} \mathrm{H}_{16} \mathrm{CuI}_{2} \mathrm{~N}_{4} \mathrm{O}_{6} \cdot 0.4 \mathrm{H}_{2} \mathrm{O}: \mathrm{C} 40.72 ; \mathrm{H} 2.78 ; \mathrm{N} 5.94 \%$. Found: $\mathrm{C} 40.69 ; \mathrm{H} 2.75$; N 5.90\%. IR (KBr, $\left.v_{\text {max }} / \mathrm{cm}^{-1}\right)$ : $3419(\mathrm{O}-\mathrm{H})$, 
3099 (C-H arom.), 1691 and $1640(\mathrm{C}=\mathrm{O}), 1599(\mathrm{C}=\mathrm{C})$, 1273 (C-O), 1001 (C-N=N-C). UV-Vis [dmso; $\lambda / \mathrm{nm}$ (log $\varepsilon)]: 281$ (4.61), 437 (3.57). Diffuse reflectance $[\lambda / \mathrm{nm}]: 636$.

\section{$\left[\mathrm{Cu}(\mathbf{L 5})_{2}\right](\mathbf{5})$}

From $404 \mathrm{mg}$ of HL5. Yield: $730 \mathrm{mg}, 84 \%$; mp 224-226 ${ }^{\circ} \mathrm{C}$, with decomposition. Anal. calcd. for $\mathrm{C}_{32} \mathrm{H}_{16} \mathrm{CuI}_{2} \mathrm{~N}_{4} \mathrm{O}_{6} \cdot 0.3 \mathrm{H}_{2} \mathrm{O}: \mathrm{C} 41.51 ; \mathrm{H} 2.61 ; \mathrm{N} 6.05 \%$. Found: $\mathrm{C} 41.49$; H 2.57; N 6.00\%. IR (KBr, $\left.v_{\text {max }} / \mathrm{cm}^{-1}\right): 3430$ (O-H), 3066 (C-H arom.), 1690 and $1640(\mathrm{C}=\mathrm{O}), 1585$ $(\mathrm{C}=\mathrm{C}), 1273$ (C-O), 1001 (C-N=N-C). UV-Vis [dmso; $\lambda / \mathrm{nm}(\log \varepsilon)]: 271$ (4.63), 460 (3.27), 582 (2.17).

\section{$\left[\mathrm{Cu}(\mathbf{L 6})_{2}\right](\mathbf{6})$}

From $404 \mathrm{mg}$ of HL6. Yield: $617 \mathrm{mg}, 71 \%$; mp 205-207 ${ }^{\circ} \mathrm{C}$, with decomposition. Anal. calcd. for $\mathrm{C}_{32} \mathrm{H}_{16} \mathrm{CuI}_{2} \mathrm{~N}_{4} \mathrm{O}_{6} \cdot 0.3 \mathrm{H}_{2} \mathrm{O}: \mathrm{C} 41.51 ; \mathrm{H} 2.61 ; \mathrm{N} 6.05 \%$. Found: $\mathrm{C} 41.45$; H 2.59; N 5.97\%. IR (KBr, $\left.v_{\max } / \mathrm{cm}^{-1}\right): 3431$ $(\mathrm{O}-\mathrm{H}), 3067$ (C-H arom.), 1690 and $1640(\mathrm{C}=\mathrm{O}), 1585$ $(\mathrm{C}=\mathrm{C}), 1274(\mathrm{C}-\mathrm{O}), 1001$ (C-N=N-C). UV-Vis [dmso; $\lambda / \mathrm{nm}$ (log $\varepsilon$ )]: 270 (4.49), 423 (3.36), 583 (2.25).

$\left[\mathrm{Cu}(\mathbf{L 7})_{2}\right](7)$

From $322 \mathrm{mg}$ of HL7. Yield: $444 \mathrm{mg}, 63 \%$; mp 231-232 ${ }^{\circ} \mathrm{C}$, with decomposition. Anal. calcd. for $\mathrm{C}_{34} \mathrm{H}_{18} \mathrm{CuN}_{4} \mathrm{O}_{10} \cdot 0.1 \mathrm{H}_{2} \mathrm{O}: \mathrm{C} 56.24 ; \mathrm{H} 3.05 ; \mathrm{N} 7.72 \%$. Found: C 56.20; H 3.01; N 7.69\%. IR (KBr, $\left.v_{\max } / \mathrm{cm}^{-1}\right): 3400-2700$ (O-H), 3069 (C-H arom.), 1688 and $1639(\mathrm{C}=\mathrm{O}), 1586$ $(\mathrm{C}=\mathrm{C}), 1271(\mathrm{C}-\mathrm{O}), 1001(\mathrm{C}-\mathrm{N}=\mathrm{N}-\mathrm{C}) . \mathrm{UV}-\mathrm{Vis}$ [dmso; $\lambda / \mathrm{nm}(\log \varepsilon)]: 271$ (4.51), 422 (3.64), 584 (2.02).

$\left[\mathrm{Cu}(\mathbf{L 8})_{2}\right](8)$

From $322 \mathrm{mg}$ of HL8. Yield: $451 \mathrm{mg}, 64 \%$; mp 280-282 ${ }^{\circ} \mathrm{C}$, with decomposition. Anal. calcd. for $\mathrm{C}_{34} \mathrm{H}_{18} \mathrm{CuN}_{4} \mathrm{O}_{10} \cdot 0.1 \mathrm{H}_{2} \mathrm{O}: \mathrm{C} 56.24 ; \mathrm{H} 3.05 ; \mathrm{N} 7.72 \%$. Found: $\mathrm{C} 56.21$; H 3.04; N 7.64\%. IR (KBr, $\left.v_{\text {max }} / \mathrm{cm}^{-1}\right): 3420-2669$ (O-H), 3081 (C-H arom.), 1690 and $1640(\mathrm{C}=\mathrm{O}), 1591$ $(\mathrm{C}=\mathrm{C}), 1280$ (C-O), 1001 (C-N=N-C). UV-Vis [dmso; $\lambda / \mathrm{nm}(\log \varepsilon)]: 269$ (4.67), 406 (3.68), 584 (2.13).

\section{$\left[\mathrm{Cu}(\boldsymbol{L 9})_{2}\right](\mathbf{9})$}

From $303 \mathrm{mg}$ of HL9. Yield: $607 \mathrm{mg}, 91 \%$; mp 269-272 ${ }^{\circ} \mathrm{C}$, with decomposition. Anal. calcd. for $\mathrm{C}_{35} \mathrm{H}_{20} \mathrm{CuN}_{6} \mathrm{O}_{6} \cdot 0.2 \mathrm{H}_{2} \mathrm{O}: \mathrm{C} 57.83 ; \mathrm{H} 3.14 ; \mathrm{N} 11.90 \%$. Found: C 57.74; H 3.11; N 11.85\%. IR (KBr, $\left.v_{\max } / \mathrm{cm}^{-1}\right): 3430(\mathrm{O}-\mathrm{H})$, 3090 (C-H arom.), 1689 and $1650(\mathrm{C}=\mathrm{O}), 1585(\mathrm{C}=\mathrm{C})$, 1261 (C-O), 975 (C-N=N-C). UV-Vis [dmso; $\lambda / \mathrm{nm}$ (log ع)]: 272 (4.82), 419 (3.44). Diffuse reflectance $[\lambda / \mathrm{nm}]$ : 635 .

\section{$\left[\mathrm{Cu}(\mathbf{L 1 0})_{2}\right](\mathbf{1 0})$}

From $303 \mathrm{mg}$ of HL10. Yield: $594 \mathrm{mg}$, 89\%; mp
207-208 ${ }^{\circ} \mathrm{C}$, with decomposition. Anal. calcd. for $\mathrm{C}_{35} \mathrm{H}_{20} \mathrm{CuN}_{6} \mathrm{O}_{6} \cdot 0.8 \mathrm{H}_{2} \mathrm{O}: \mathrm{C} 50.15 ; \mathrm{H} 4.21 ; \mathrm{N} 10.32 \%$. Found: C 50.13; H 4.17; N 10.28\%. IR ( $\left.\mathrm{KBr}, \mathrm{v}_{\max } / \mathrm{cm}^{-1}\right): 3455(\mathrm{O}-\mathrm{H})$, 3090 (C-H arom.), 1693 and $1647(\mathrm{C}=\mathrm{O}), 1598(\mathrm{C}=\mathrm{C})$, 1264 (C-O), 972 (C-N=N-C). UV-Vis [dmso; $\lambda / \mathrm{nm}$ (log $\varepsilon)]: 277$ (4.68), 415 (3.38). Diffuse reflectance $[\lambda / \mathrm{nm}]: 609$.

\section{$\left[\mathrm{Cu}(\mathrm{L11})_{2}\right](\mathbf{1 1})$}

From $323 \mathrm{mg}$ of HL10. Yield: $544 \mathrm{mg}, 77 \%$; mp 291-292 ${ }^{\circ} \mathrm{C}$, with decomposition. Anal. calcd. for $\mathrm{C}_{32} \mathrm{H}_{18} \mathrm{CuN}_{6} \mathrm{O}_{10} \cdot 0.4 \mathrm{H}_{2} \mathrm{O}$ : C 49.14; $\mathrm{H} 3.35 ; \mathrm{N} 10.75 \%$. Found: C 49.11; H 3.30; N 10.71\%. IR ( $\left.\mathrm{KBr}, \mathrm{v}_{\max } / \mathrm{cm}^{-1}\right)$ : $3443(\mathrm{O}-\mathrm{H}), 3075$ (C-H arom.), $1668(\mathrm{C}=\mathrm{O}), 1607(\mathrm{C}=\mathrm{C})$, 1245 (C-O), 975 (C-N=N-C). UV-Vis [dmso; $\lambda / \mathrm{nm}(\log \varepsilon)]$ : 280 (4.58), 499 (3.65).

$\left[\mathrm{Cu}(\mathrm{L12})_{2}\right](\mathbf{1 2})$

From $323 \mathrm{mg}$ of HL12. Yield: $558 \mathrm{mg}$, 79\%; mp 244-246 ${ }^{\circ} \mathrm{C}$, with decomposition. Anal. calcd. for $\mathrm{C}_{32} \mathrm{H}_{18} \mathrm{CuN}_{6} \mathrm{O}_{10} \cdot 0.2 \mathrm{H}_{2} \mathrm{O}$ : C 51.51; H 2.97; N $11.26 \%$. Found: C 51.49; H 2.95; N 11.21\%. IR ( $\left.\mathrm{KBr}, \mathrm{v}_{\max } / \mathrm{cm}^{-1}\right)$ : 3443 (O-H), 3077 (C-H arom.), 1672 (C=O), 1607 (C=C), 1242 (C-O), $976(\mathrm{C}-\mathrm{N}=\mathrm{N}-\mathrm{C})$. UV-Vis [dmso; $\lambda / \mathrm{nm}(\log \varepsilon)]$ : 275 (4.64), 506 (3.63). Diffuse reflectance $[\lambda / \mathrm{nm}]: 637$.

$\left[\mathrm{Cu}(\mathrm{L13})_{2}\right](\mathbf{1 3})$

From $323 \mathrm{mg}$ of HL13. Yield: $587 \mathrm{mg}, 83 \%$; mp 257-259 ${ }^{\circ} \mathrm{C}$, with decomposition. Anal. calcd. for $\mathrm{C}_{32} \mathrm{H}_{18} \mathrm{CuN}_{6} \mathrm{O}_{10} \cdot 0.6 \mathrm{H}_{2} \mathrm{O}$ : C 46.98; H 3.70; $\mathrm{N} 10.27 \%$. Found: C 46.90; H 3.66; N 10.24\%. IR ( $\left.\mathrm{KBr}, \mathrm{v}_{\max } / \mathrm{cm}^{-1}\right)$ : 3457 (O-H), 3073 (C-H arom.), 1675 (C=O), 1603 (C=C), 1235 (C-O), 987 (C-N=N-C). UV-Vis [dmso; $\lambda / \mathrm{nm}(\log \varepsilon)]$ : 277 (4.54), 439 (3.77). Diffuse reflectance $[\lambda / \mathrm{nm}]: 620$.

Antibacterial activity of compounds HL1-HL13 and complexes 1-13

\section{Experimental}

The cultures were maintained on Mueller Hinton agar at $8{ }^{\circ} \mathrm{C}$. The inoculum suspension of each strain, in Mueller Hinton broth, was prepared to attain a final inoculum of 108 $\mathrm{CFU} \mathrm{mL}^{-1}(\mathrm{OD}=0.08-0.1$ at $\lambda=625 \mathrm{~nm}$, ThermoSpectronic Genesys 10UV) and diluted 1:10 by the broth microdilution procedure according to the M7-A6 document (National Committee for Clinical Laboratory Standards Methods for Dilution Antimicrobial Susceptibility Tests for Bacteria that Grow Aerobically, 6th ed.; Approved Standard NCCLS Document M7-A6: Wayne, PA, 2003). Minimum inhibitory concentration was determined using 96-well microtitre plates filled with Mueller Hinton broth (100 $\mu \mathrm{L}$ per well). All samples were dissolved in dmso/ 
Mueller Hinton broth and tested in eight concentrations $\left(3 \times 10^{-3}-0.02 \mathrm{mmol} \mathrm{mL}^{-1}\right)$. Chloramphenicol (Aldrich) was used as positive control. For sterility and growth control, a culture medium without compounds was used. The inoculum suspension $(5 \mu \mathrm{L})$ was applied into the wells and the microplates were incubated at $37^{\circ} \mathrm{C}$ overnight. Afterwards, $20 \mu \mathrm{L}$ of $0.2 \mathrm{mg} \mathrm{mL}^{-1}$ of $p$-iodonitrotetrazolium chloride (p-INT) (Sigma) aqueous solution was added and once more incubated for $1 \mathrm{~h}$ at $37^{\circ} \mathrm{C}$. The MIC was defined as the lowest concentration of the compounds that inhibited the antibacterial visible growth as indicated by the p-INT colorimetric reagent.
The antibacterial activity of the hydrazono compounds HL1-HL13 and their respective copper(II) complexes 1-13 was evaluated against seven strains of bacteria: Bacillus cereus, Bacillus subtilis, Escherichia coli, Enterococcus faecalis, Klebsiella pneumoniae, Pseudomonas aeruginosa and Staphylococcus aureus. The results are reported in Table S4 below, where the MIC values are expressed in $\mu \mathrm{mol} \mathrm{L} \mathrm{L}^{-1}$. Chloramphenicol was used as a positive control in all tests. Compounds 2-hydroxy-1,4-naphthoquinone (lawsone) and $\mathrm{CuCl}_{2} \cdot 2 \mathrm{H}_{2} \mathrm{O}$ were also tested for comparison.

Results

Table S4. Antibacterial activity data of compounds $\mathbf{H L I}-\mathbf{H L 1 3}$, complexes 1-13, lawsone and $\mathrm{CuCl}_{2} \cdot 2 \mathrm{H}_{2} \mathrm{O}$

\begin{tabular}{|c|c|c|c|c|c|c|c|c|}
\hline Compound & Entry & $\mathrm{BC}$ & BS & $\mathrm{EC}$ & $\mathrm{EF}$ & KP & PA & SA \\
\hline HL1 ( R = OMe) & 1 & $>200$ & $>200$ & $>200$ & $>200$ & $>200$ & $>200$ & $>200$ \\
\hline HL2 $\left(\mathrm{R}=\mathrm{N}_{2}-\mathrm{C}_{6} \mathrm{H}_{5}\right)$ & 2 & $>200$ & $>200$ & $>200$ & $>200$ & $>200$ & $>200$ & $>200$ \\
\hline HL3 $(\mathrm{R}=4-\mathrm{Cl})$ & 3 & $>200$ & $>200$ & $>200$ & $>200$ & $>200$ & $>200$ & $>200$ \\
\hline HL4 (R = 4-I) & 4 & $>200$ & $>200$ & $>200$ & $>200$ & $>200$ & $>200$ & $>200$ \\
\hline $\operatorname{HL5}(\mathrm{R}=3-\mathrm{I})$ & 5 & 90 & 90 & 20 & 180 & $>200$ & $>200$ & $>200$ \\
\hline HL6 $(\mathrm{R}=2-\mathrm{I})$ & 6 & $>200$ & $>200$ & $>200$ & $>200$ & $>200$ & $>200$ & $>200$ \\
\hline HL7 ( $\mathrm{R}=4-\mathrm{OOH})$ & 7 & $>200$ & $>200$ & $>200$ & $>200$ & $>200$ & $>200$ & $>200$ \\
\hline HL8 (R = 3-OOH) & 8 & $>200$ & $>200$ & $>200$ & $>200$ & $>200$ & $>200$ & $>200$ \\
\hline HL9 (R = 4-CN) & 9 & $>200$ & $>200$ & $>200$ & $>200$ & $>200$ & $>200$ & $>200$ \\
\hline $\operatorname{HL10}(\mathrm{R}=3-\mathrm{CN})$ & 10 & $>200$ & $>200$ & $>200$ & $>200$ & $>200$ & $>200$ & $>200$ \\
\hline $\operatorname{HL11}\left(\mathrm{R}=4-\mathrm{NO}_{2}\right)$ & 11 & $>200$ & $>200$ & $>200$ & $>200$ & $>200$ & $>200$ & $>200$ \\
\hline HL12 $\left(\mathrm{R}=3-\mathrm{NO}_{2}\right)$ & 12 & $>200$ & $>200$ & $>200$ & $>200$ & $>200$ & $>200$ & $>200$ \\
\hline $\operatorname{HL13}\left(\mathrm{R}=2-\mathrm{NO}_{2}\right)$ & 13 & 180 & $>200$ & $>200$ & $>200$ & $>200$ & $>200$ & $>200$ \\
\hline Lawsone & 14 & $>200$ & $>200$ & $>200$ & $>200$ & $>200$ & $>200$ & $>200$ \\
\hline Chloramphenicol & 15 & $40-90$ & $20-40$ & 90 & 90 & $40-90$ & 40 & $40-90$ \\
\hline $1(\mathrm{R}=\mathrm{OMe})$ & 18 & $>200$ & $>200$ & $>200$ & $>200$ & $>200$ & $>200$ & $>200$ \\
\hline $2\left(\mathrm{R}=\mathrm{N}_{2}-\mathrm{C}_{6} \mathrm{H}_{5}\right)$ & 19 & $>200$ & $>200$ & $>200$ & $>200$ & $>200$ & $>200$ & $>200$ \\
\hline $3(\mathrm{R}=4-\mathrm{Cl})$ & 20 & $>200$ & $>200$ & $>200$ & $>200$ & $>200$ & $>200$ & $>200$ \\
\hline $4(\mathrm{R}=4-\mathrm{I})$ & 21 & $>200$ & $>200$ & 180 & $>200$ & $>200$ & $>200$ & $>200$ \\
\hline $5(\mathrm{R}=3-\mathrm{I})$ & 22 & $>200$ & $>200$ & $>200$ & $>200$ & $>200$ & $>200$ & $>200$ \\
\hline $6(\mathrm{R}=2-\mathrm{I})$ & 23 & $>200$ & $>200$ & $>200$ & $>200$ & $>200$ & $>200$ & $>200$ \\
\hline $7(\mathrm{R}=4-\mathrm{COOH})$ & 24 & $>200$ & $>200$ & $>200$ & $>200$ & $>200$ & $>200$ & $>200$ \\
\hline $8(\mathrm{R}=3-\mathrm{COOH})$ & 25 & $>200$ & $>200$ & $>200$ & $>200$ & $>200$ & $>200$ & $>200$ \\
\hline $9(\mathrm{R}=4-\mathrm{CN})$ & 26 & $>200$ & $>200$ & $>200$ & $>200$ & $>200$ & $>200$ & $>200$ \\
\hline $10(\mathrm{R}=3-\mathrm{CN})$ & 27 & $>200$ & 180 & $>200$ & $>200$ & $>200$ & $>200$ & $>200$ \\
\hline $11\left(\mathrm{R}=4-\mathrm{NO}_{2}\right)$ & 28 & $>200$ & $>200$ & $>200$ & $>200$ & $>200$ & $>200$ & $>200$ \\
\hline $12\left(\mathrm{R}=3-\mathrm{NO}_{2}\right)$ & 29 & $>200$ & $>200$ & 180 & $>200$ & $>200$ & $>200$ & $>200$ \\
\hline $13\left(\mathrm{R}=2-\mathrm{NO}_{2}\right)$ & 30 & $>200$ & $>200$ & $>200$ & $>200$ & $>200$ & $>200$ & $>200$ \\
\hline $\mathrm{CuCl}_{2} \cdot 2 \mathrm{H}_{2} \mathrm{O}$ & 31 & $>3000$ & $>3000$ & $>3000$ & $>3000$ & $>3000$ & $>3000$ & $>3000$ \\
\hline
\end{tabular}

Minimum inhibitory concentrations (MICs) are reported in $\mu \mathrm{mol} \mathrm{L^{-1 }}$. 
Antitumor activity of compounds HL1-HL13 and complexes 1-13

\section{Experimental}

The compounds (1-5 $\left.\mathrm{mg} \mathrm{mL}^{-1}\right)$ were tested for cytotoxic activity against three cancer cell lines: SF-295 (central nervous system), HCT-8 (colon), MDAMB-435 (breast) and HL-60 (human leukemia). All cell lines were maintained in RPMI 1640 medium supplemented with $10 \%$ fetal bovine serum, $2 \mathrm{mmol} \mathrm{L}^{-1}$ glutamine, $100 \mathrm{U} \mathrm{mL}^{-1}$ penicillin, and $100 \mu \mathrm{g} \mathrm{mL}^{-1}$ streptomycin at $37^{\circ} \mathrm{C}$ with $5 \%$ $\mathrm{CO}_{2}$. Each compound was dissolved in dmso and diluted with water to obtain a concentration of $1 \mathrm{mg} \mathrm{mL}^{-1}$. They were incubated with the cells for $72 \mathrm{~h}$. The negative control received the same amount of dmso $(0.005 \%$ in the highest concentration). Doxorubicin (dox, $0.1-0.58 \mu \mathrm{g} \mathrm{mL}^{-1}$ ) was used as a positive control. The cell viability was determined by reduction of the yellow dye 3-(4,5-dimethyl-2-thiazol)2,5-phenyl-2H-tetrazolium bromide (MTT) to a blue formazan product as described by Mosmann.

\section{Results}

In the Table S5 below, we present the screening of the cytotoxic activity (growth inhibition \%) of the synthesized compounds HL1-HL13, complexes 1-13 and lawsone for comparison.

Table S5. Screening of the cytotoxic activity (growth inhibition \%) of HL1-HL13, complexes 1-13 and lawsone

\begin{tabular}{|c|c|c|c|c|c|c|c|}
\hline Compound & Entry & SF295 & $\mathrm{GI} \%$ (SD) & HCT-8 & $\mathrm{GI} \%$ (SD) & MDA-MB435 & $\mathrm{GI} \%$ (SD) \\
\hline HL1 $(\mathrm{R}=\mathrm{OMe})$ & 1 & 0.65 & 1.80 & 6.48 & 5.95 & 11.00 & 6.34 \\
\hline HL2 $\left(\mathrm{R}=\mathrm{N}_{2}-\mathrm{C}_{6} \mathrm{H}_{5}\right)$ & 2 & -3.30 & 5.20 & 4.74 & 1.01 & 3.92 & 10.49 \\
\hline $\mathbf{H L 3}(\mathrm{R}=4-\mathrm{Cl})$ & 3 & 31.04 & 2.20 & 19.89 & 0.22 & 23.24 & 3.42 \\
\hline HL4 (R = 4-I) & 4 & -5.99 & 2.20 & -11.12 & 0.11 & 13.76 & 0.00 \\
\hline $\operatorname{HL5}(\mathrm{R}=3-\mathrm{I})$ & 5 & 19.38 & 1.10 & 18.86 & 6.17 & 14.19 & 5.00 \\
\hline HL6 (R = 2-I) & 6 & 25.45 & 43.27 & 92.23 & 7.85 & 67.40 & 13.17 \\
\hline HL7 $(\mathrm{R}=4-\mathrm{COOH})$ & 7 & 15.00 & 13.49 & -8.98 & 6.06 & 22.64 & 2.81 \\
\hline HL8 $(\mathrm{R}=3-\mathrm{COOH})$ & 8 & 2.07 & 0.80 & -4.07 & 6.95 & -7.12 & 0.98 \\
\hline HL9 $(\mathrm{R}=4-\mathrm{CN})$ & 9 & -7.75 & 9.09 & 7.20 & 0.22 & -0.65 & 7.44 \\
\hline HL10 (R = 3-CN) & 10 & 48.98 & 12.99 & 25.84 & 8.41 & 5.39 & 3.05 \\
\hline $\operatorname{HL12}\left(\mathrm{R}=3-\mathrm{NO}_{2}\right)$ & 12 & 17.75 & 5.00 & 9.26 & 12.79 & 3.06 & 2.20 \\
\hline $\operatorname{HL13}\left(\mathrm{R}=2-\mathrm{NO}_{2}\right)$ & 13 & 52.87 & 8.69 & 58.52 & 0.56 & 32.56 & 1.95 \\
\hline Lawsone & 14 & -35.56 & 5.29 & -36.98 & 0.48 & -54.48 & 0.78 \\
\hline dox & 15 & 83.96 & 1.30 & 91.67 & 11.78 & 96.55 & 2.44 \\
\hline $\mathbf{1}(\mathrm{R}=\mathrm{OMe})$ & 18 & -10.51 & 16.79 & -16.52 & 11.78 & 12.20 & 1.71 \\
\hline $2\left(\mathrm{R}=\mathrm{N}_{2}-\mathrm{C}_{6} \mathrm{H}_{5}\right)$ & 19 & 16.13 & 5.30 & 16.64 & 0.11 & 14.36 & 1.34 \\
\hline $3(\mathrm{R}=4-\mathrm{Cl})$ & 20 & 11.39 & 4.00 & 6.17 & 9.53 & 16.17 & 0.73 \\
\hline $4(\mathrm{R}=4-\mathrm{I})$ & 21 & 6.80 & 0.90 & 2.44 & 2.02 & 12.55 & 0.24 \\
\hline $6(\mathrm{R}=2-\mathrm{I})$ & 23 & 5.11 & 5.30 & -5.18 & 3.37 & 25.66 & 14.39 \\
\hline $9(\mathrm{R}=4-\mathrm{CN})$ & 26 & 19.87 & 1.40 & 30.28 & 0.11 & 20.14 & 7.32 \\
\hline $10(\mathrm{R}=3-\mathrm{CN})$ & 27 & -7.61 & 4.90 & -6.68 & 3.25 & 7.89 & 8.29 \\
\hline $12\left(\mathrm{R}=3-\mathrm{NO}_{2}\right)$ & 29 & -2.24 & 7.49 & 8.47 & 5.61 & -3.32 & 10.98 \\
\hline $13\left(\mathrm{R}=2-\mathrm{NO}_{2}\right)$ & 30 & 69.26 & 29.88 & 96.03 & 7.18 & 54.20 & 1.34 \\
\hline
\end{tabular}




\section{EPR spectra of the copper(II) complexes 1-13}

The X-band EPR Hamiltonian parameters of frozen solutions of copper(II) complexes in dmso are shown in Table S6 below.

Table S6. Spin-Hamiltonian parameters used in the simulated spectra of the copper(II) ion in complexes 1-13

\begin{tabular}{lccccc}
\hline Complexes & $\mathrm{A}_{\perp}\left(\times 10^{-4} \mathrm{~cm}^{-1}\right)$ & $\mathrm{A}_{\|}\left(\times 10^{-4} \mathrm{~cm}^{-1}\right)$ & $\mathrm{g}_{\perp}$ & $\mathrm{g}_{\|}$ & 2.2500 \\
\hline $\mathbf{1}$ & 25 & 170 & 2.078 & 2.2420 & 132 \\
$\mathbf{2}$ & 25 & 171 & 2.082 & 2.4000 & 131 \\
$\mathbf{3}$ & 25 & 120 & 2.075 & 2.4000 & 200 \\
$\mathbf{4}$ & 25 & 134 & 2.078 & 2.2250 & 185 \\
$\mathbf{5}$ & 25 & 170 & 2.097 & 2.2240 & 131 \\
$\mathbf{6}$ & 25 & 170 & 2.092 & 2.2450 & 131 \\
$\mathbf{7}$ & 25 & 170 & 2.090 & 2.2450 & 132 \\
$\mathbf{8}$ & 25 & 170 & 2.090 & 2.3000 & 132 \\
$\mathbf{9}$ & 25 & 171 & 2.095 & 2.2530 & 134 \\
$\mathbf{1 0}$ & 25 & 170 & 2.078 & 2.4000 & 132 \\
$\mathbf{1 1}$ & 25 & 135 & 2.060 & 2.2620 & 178 \\
$\mathbf{1 2}$ & 25 & 162 & 2.060 & 2.2300 & 129 \\
\hline
\end{tabular}

*OFR means organic free radical, a very sharp EPR line observed over the perpendicular copper(II) spectrum of complex 13. 
Cyclic voltammograms of compounds HL1-L13 and $\left[\mathrm{Cu}(\mathbf{L 1})_{2}\right]-\left[\mathrm{Cu}(\mathbf{L 1 3})_{2}\right]$

Cyclic voltammograms were obtained on an Epsilon BAS potentiostat-galvanostat from $1 \times 10^{-3} \mathrm{~mol} \mathrm{~L}^{-1}$ solutions in dmso containing $0.1 \mathrm{~mol} \mathrm{~L}^{-1}$ of $\left(\mathrm{Bu}_{4} \mathrm{~N}\right) \mathrm{BF}_{4}$
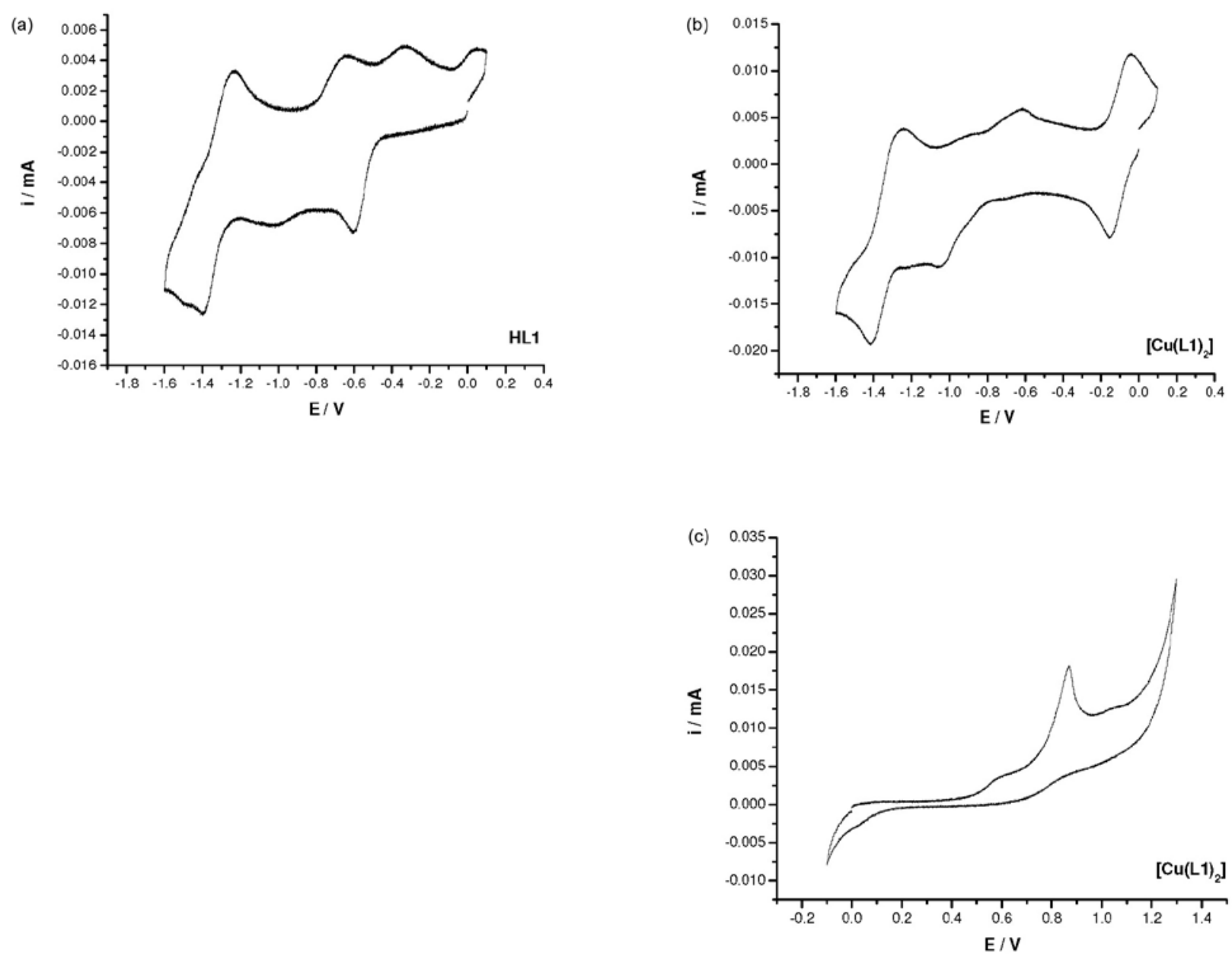

Figure S31. Cyclic voltammograms registered for $\mathrm{HL1}$ (a) and $\left[\mathrm{Cu}(\mathbf{L 1})_{2}\right]$ (b) and (c). The process attributed the redox couple $\mathrm{Cu} / \mathrm{Cu}{ }^{2+}$ in $\left[\mathbf{C u}(\mathbf{L 1})_{2}\right]$ is not visible in the range presented in voltammogram (c), but can be seen in voltammogram (b) scan in the range from -0.4 to $1.8 \mathrm{~V}$.
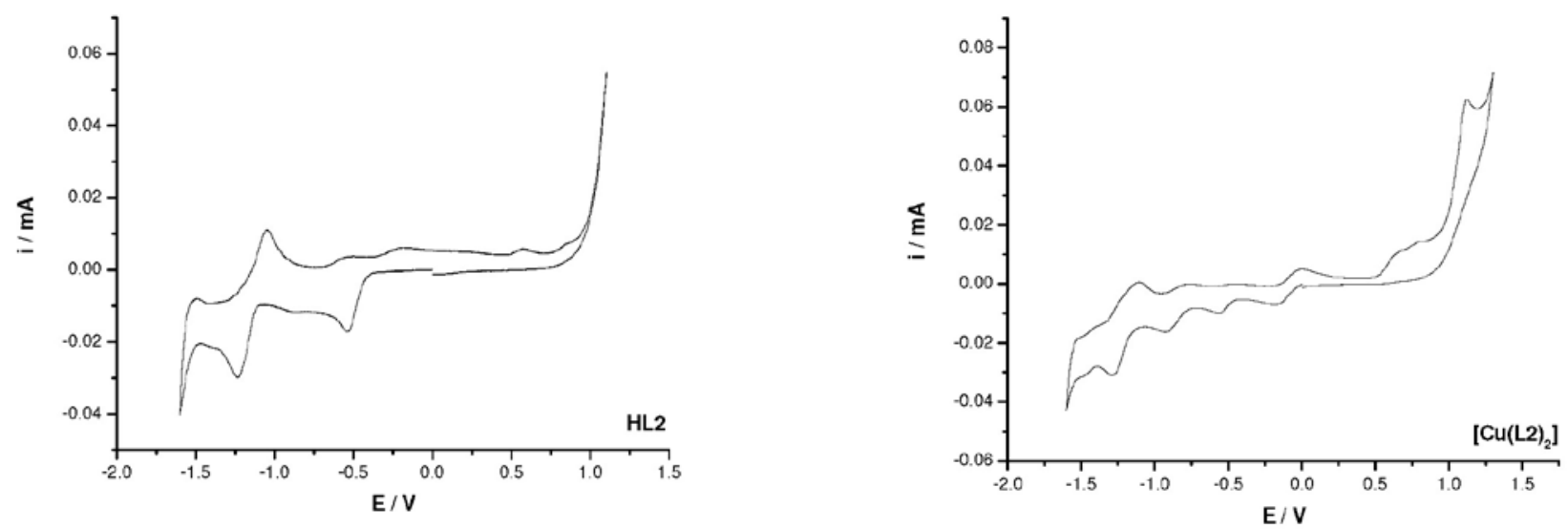

Figure S32. Cyclic voltammograms registered for $\mathbf{H L 2}$ and $\left[\mathrm{Cu}(\mathbf{L 2})_{2}\right]$.

as supporting electrolyte, at room temperature and under argon atmosphere. A standard three component system was used: a carbon-glassy working electrode, a platinum wire auxiliary electrode, and an $\mathrm{Ag} / \mathrm{AgCl}$ reference electrode for organic media. Ferrocene was used as an internal standard $\left(\mathrm{E}_{1 / 2} 0.40 \mathrm{~V} v s\right.$. NHE).

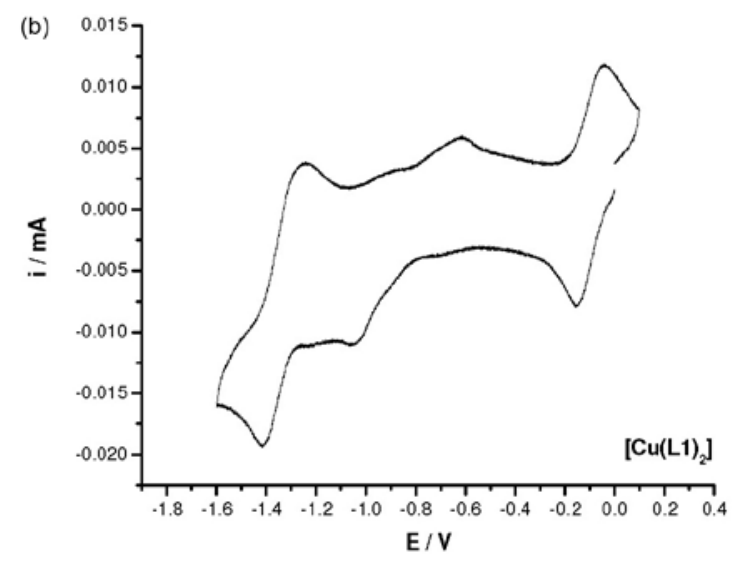



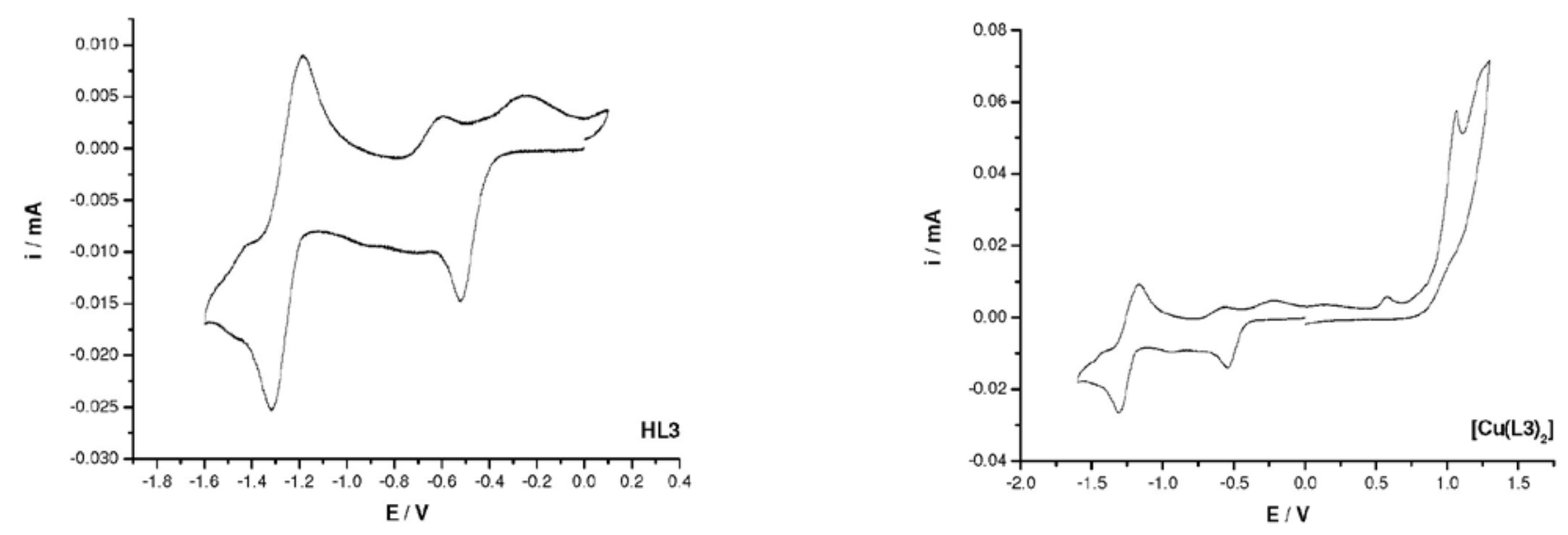

Figure S33. Cyclic voltammograms registered for $\mathbf{H L 3}$ and $\left[\mathrm{Cu}(\mathbf{L 3})_{2}\right]$.
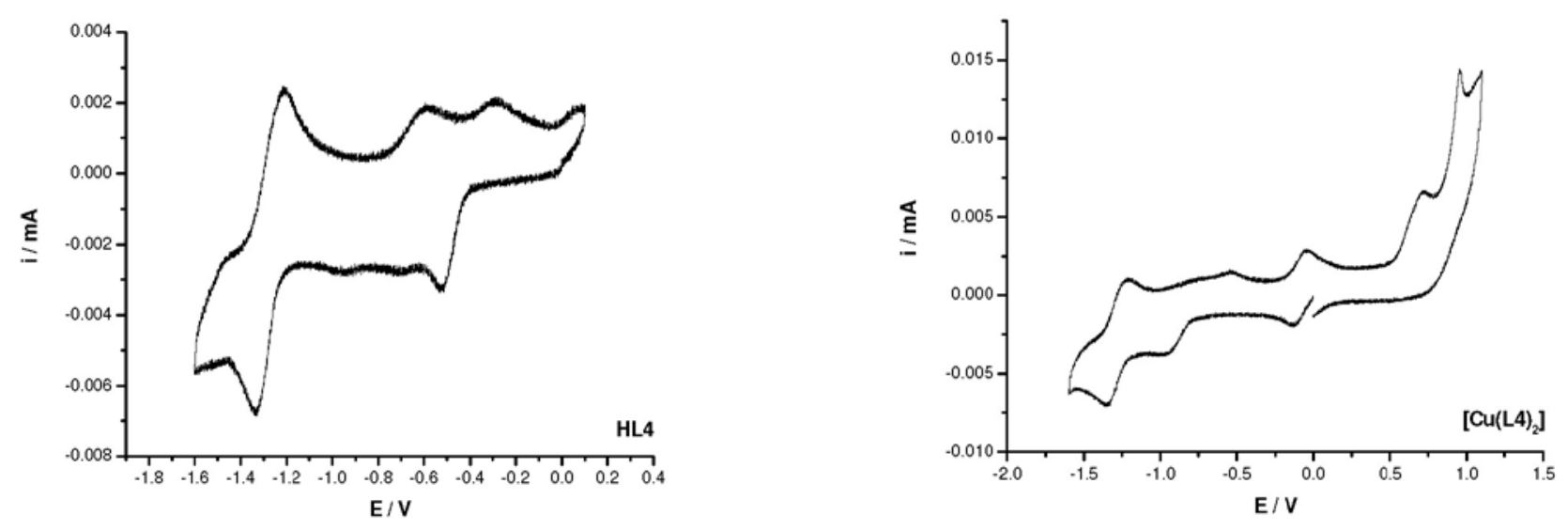

Figure S34. Cyclic voltammograms registered for $\mathbf{H L 4}$ and $\left[\mathrm{Cu}(\mathbf{L 4})_{2}\right]$.
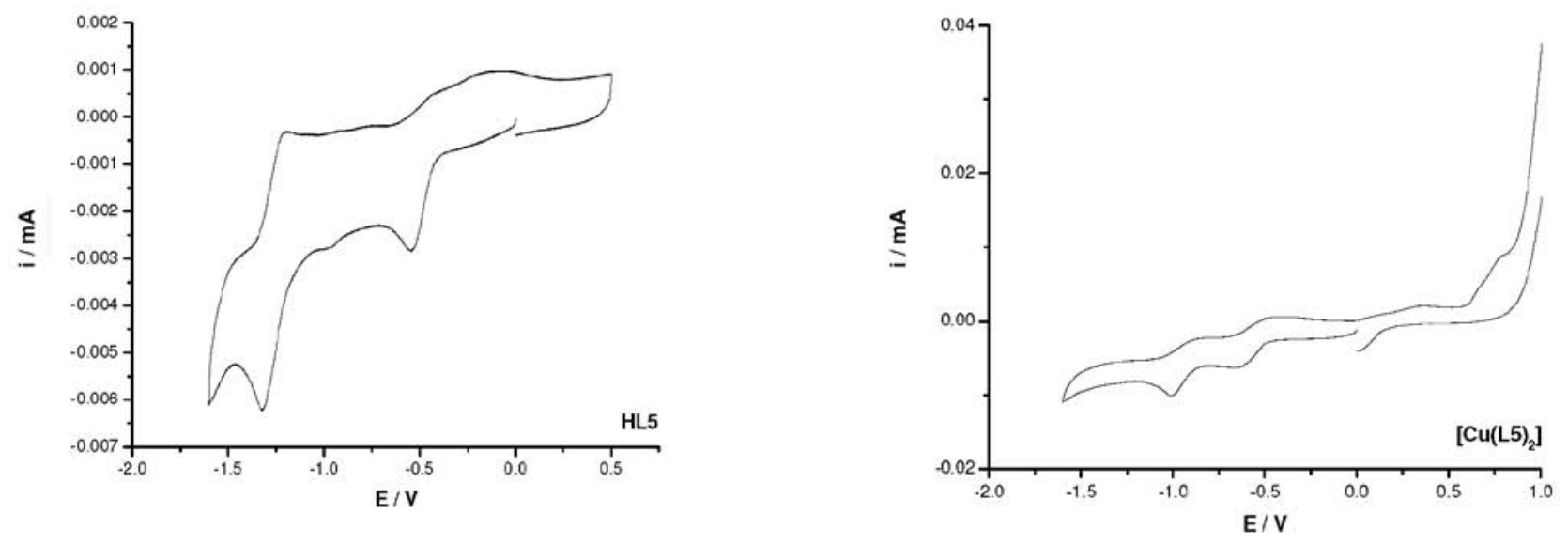

Figure S35. Cyclic voltammograms registered for $\mathbf{H L 5}$ and $\left[\mathrm{Cu}(\mathbf{L 5})_{2}\right]$. 


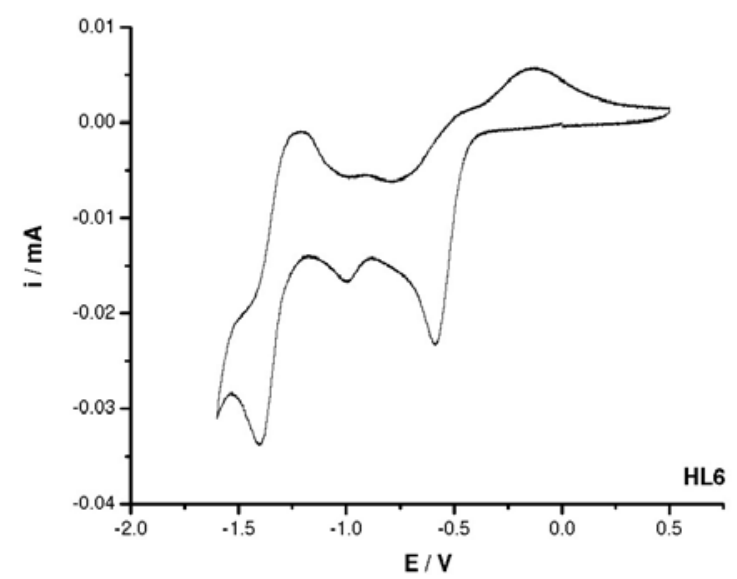

Figure S36. Cyclic voltammograms registered for $\mathbf{H L 6}$ and $\left[\mathrm{Cu}(\mathbf{L 6})_{2}\right]$.

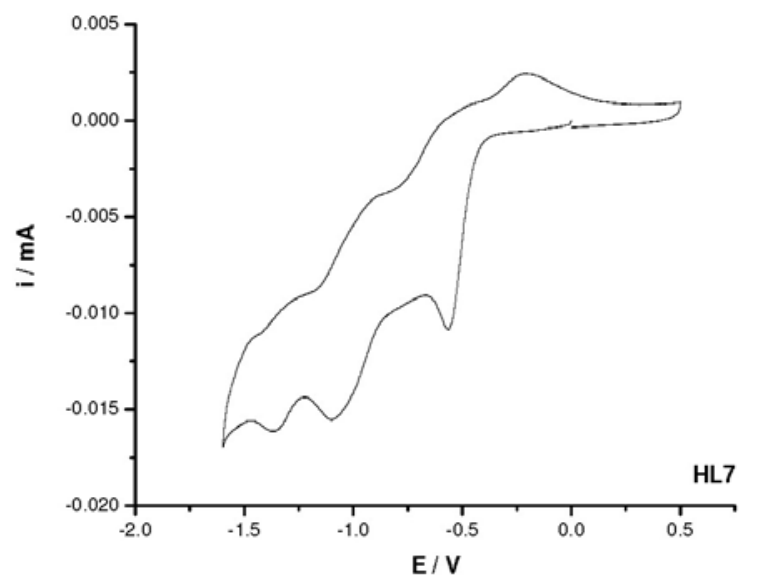

Figure S37. Cyclic voltammograms registered for $\mathbf{H L 7}$ and $\left[\mathrm{Cu}(\mathbf{L 7})_{2}\right]$.

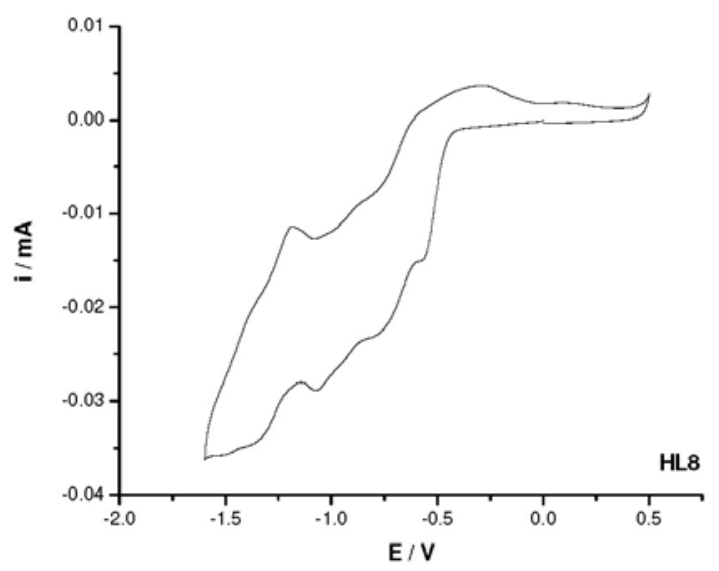

Figure S38. Cyclic voltammograms registered for $\mathbf{H L 8}$ and $\left[\mathrm{Cu}(\mathbf{L 8})_{2}\right]$.
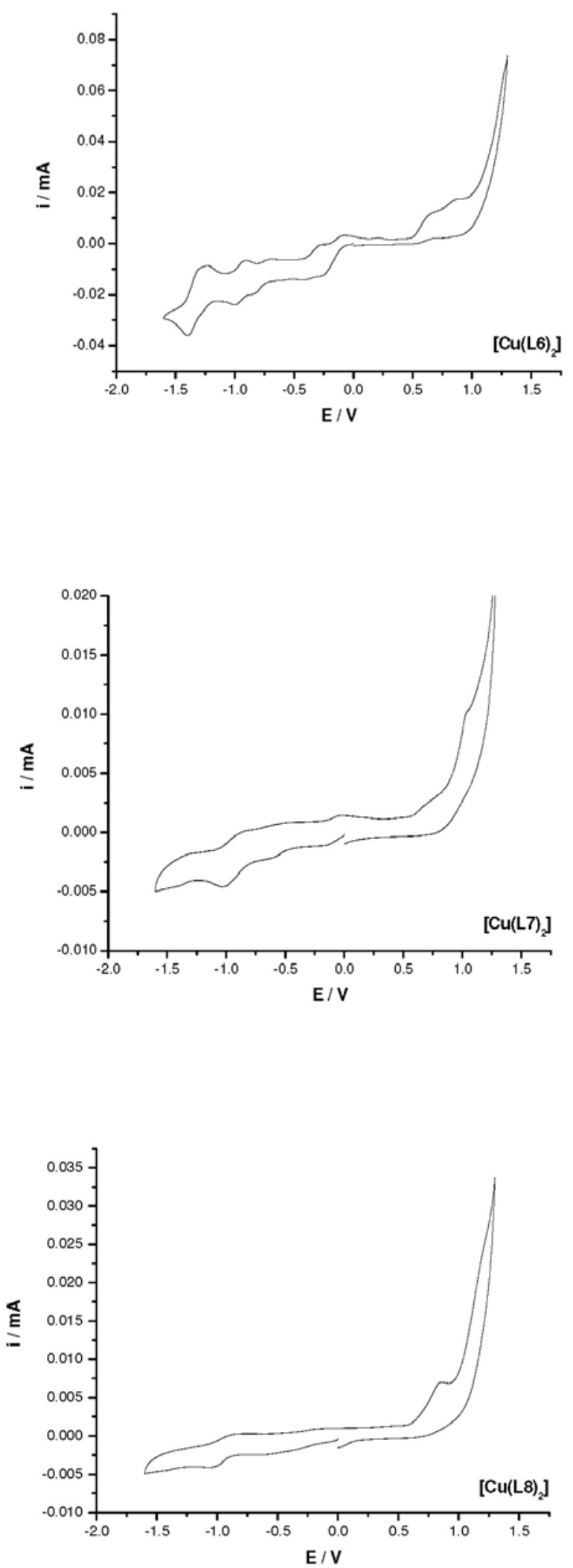


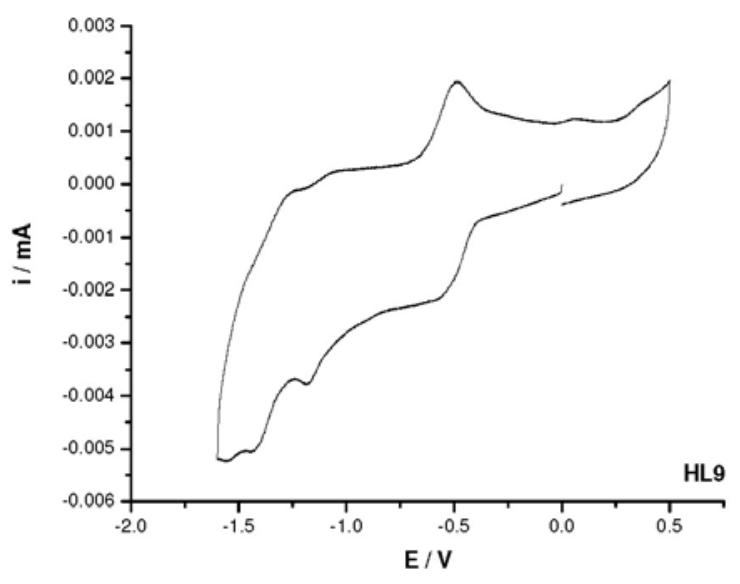

Figure S39. Cyclic voltammograms registered for $\mathbf{H L 9}$ and $\left[\mathrm{Cu}(\mathbf{L 9})_{2}\right]$.

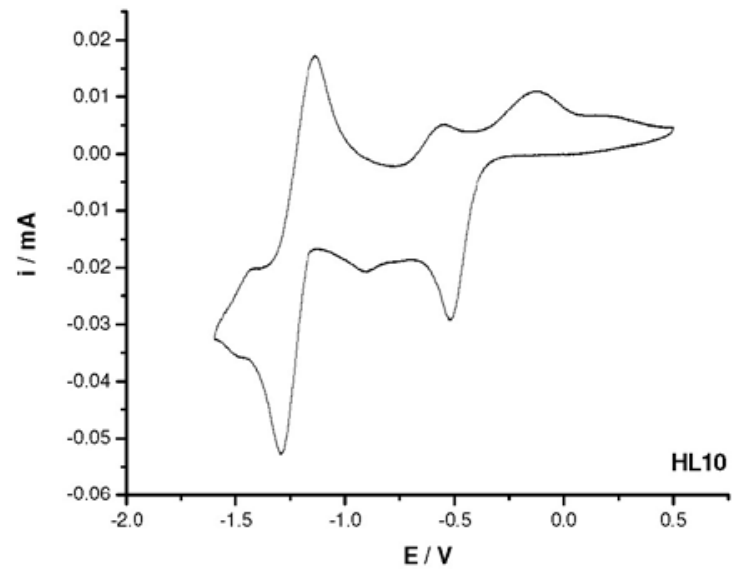

Figure S40. Cyclic voltammograms registered for $\mathbf{H L 1 0}$ and $\left[\mathrm{Cu}(\mathbf{L 1 0})_{2}\right]$.

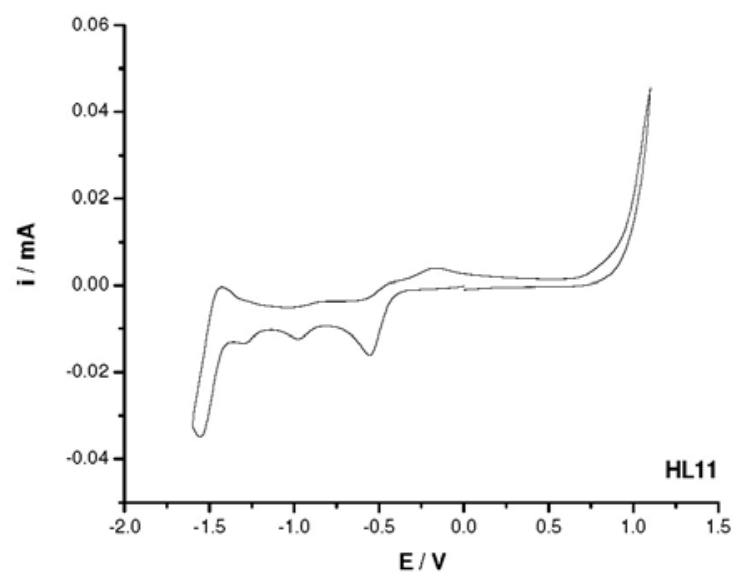

Figure S41. Cyclic voltammograms registered for $\mathbf{H L 1 1}$ and $\left[\mathrm{Cu}(\mathbf{L 1 1})_{2}\right]$.
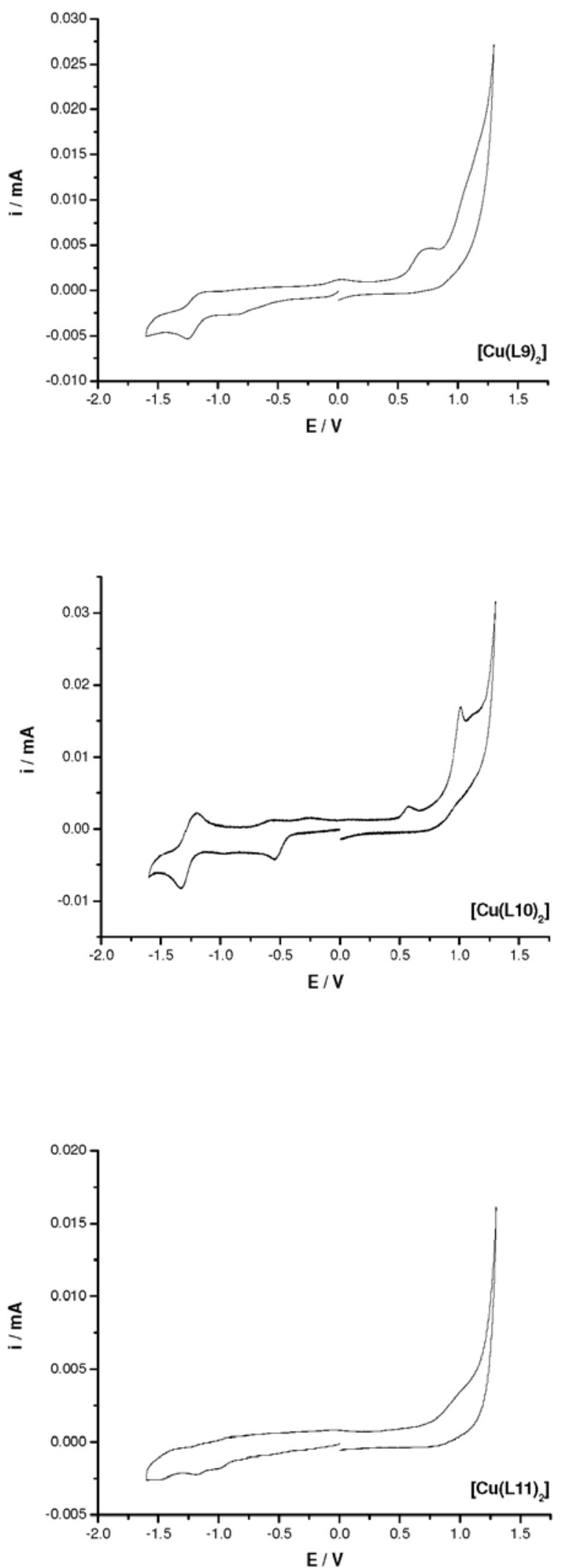

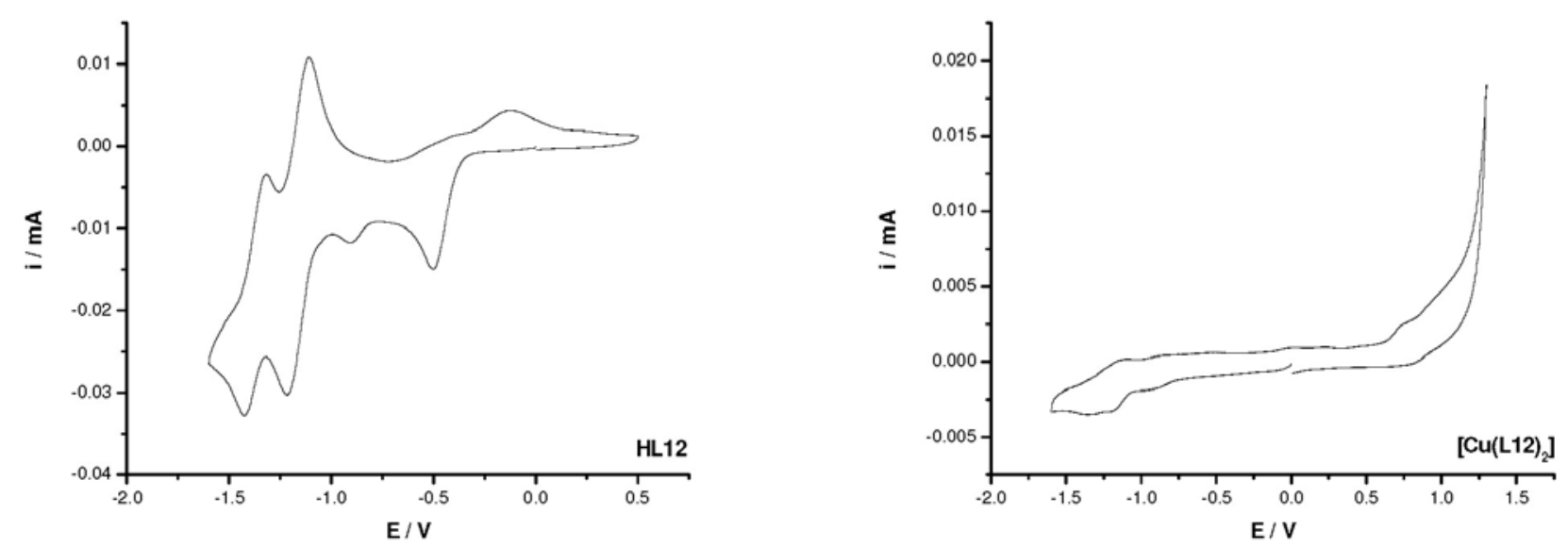

Figure S42. Cyclic voltammograms registered for $\mathrm{HL12}$ and $\left[\mathrm{Cu}(\mathbf{L 1 2})_{2}\right]$.
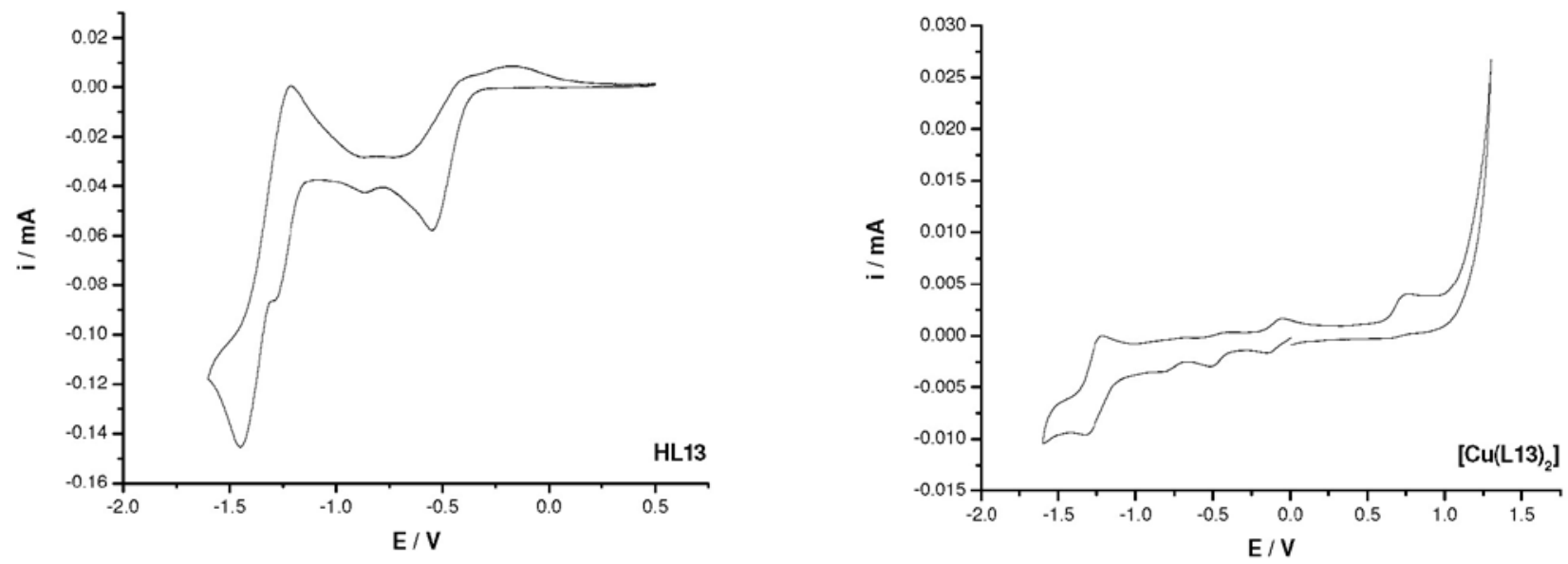

Figure S43. Cyclic voltammograms registered for $\mathbf{H L 1 3}$ and $\left[\mathrm{Cu}(\mathbf{L 1 3})_{2}\right]$. 